\title{
Silurian Corals from
}

Maine and Quebec

GEOLOGIGAL SURVEY PROFESSIONAL PAPER 430

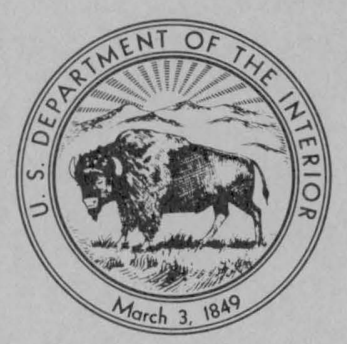




\section{Silurian Corals from}

\section{Maine and Quebec}

A. Silurian Corals from the Moose River Synclinorium, Maine

By ERWIN C. STUMM

B. Silurian Rugose Corals from the Lake Témiscouata area, Quebec By WILLIAM A. OLIVER, JR.

C. A New Kodonophyllum and Associated Rugose Corals from the Lake Matapedia Area, Quebec

By WILLIAM A. OLIVER, JR.

GEOLOGICAL SURVEY PROFESSIONAL PAPER 430

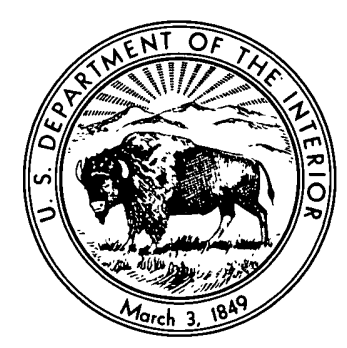

UNITED STATES GOVERNMENT PRINTING OFFICE, WASHINGTON : 1962 


\title{
UNITED STATES DEPARTMENT OF THE INTERIOR
}

\section{STEWART L. UDALL, Secretary}

\section{GEOLOGICAL SURVEY}

\author{
Thomas B. Nolan, Director
}

The U.S. Geological Survey Library has cataloged this publication as follows :

\section{Stumm, Erwin Charles, 1908-}

Silurian corals from Maine and Quebec. Washington, U.S. Govt. Print. Off., 1962.

vii, 32 p. illus., map, diagrs., tables. $29 \mathrm{~cm}$. (U.S. Geological Survey. Professional paper 430)

Includes bibliographies.

Contents.-A. Silurian corals from the Moose River synclinorium, Maine, by Erwin C. Stumm.-B. Silurian Rugose corals from the Lake Témiscouata area, Quebec, by William A. Oliver, Jr.-C. A new Kodonophyllum and associated Rugose corals from the Lake Matapedia area, Quebec, by William A. Oliver, Jr.

(Continued on next card)

\section{Stumm, Erwin Charles, 1908-}

(Card 2)

Silurian corals from Maine and Quebec. 1962.

1. Paleontology-Quebec. 2. Paleontology-Maine. 3. Paleontology-Silurian. 4. Corals, Fossil. I. Stumm, Erwin Charles, 1908Silurian corals from the Moose River synclinorium, Maine. II. Oliver, William Albert, 1926- Silurian Rugose corals from the Lake Témiscouata area, Quebec. III. Oliver, William Albert, 1926- A new Kodonophyllum and associated Rugose corals from the Lake Matapedia area, Quebec. IV. Title. (Series) 


\section{O N T ENT S}

corals from the Moose River synclinorium, Maine, by Erwin C. Stumm --

(B) Silurian rugose corals from the Lake Témiscouata area, Quebec, by William A. 11 Oliver, Jr . . . . . .

(C) A new Kodonophyllum and associated rugose corals from the Lake Matapedia area, Quebec, by William A. Oliver, Jr. 


\section{Silurian Corals from the}

Moose River Synclinorium

\section{Maine}

By ERWIN C. STUMM

SILURIAN CORALS FROM MAINE AND QUEBEC

GEOLOGICAL SURVEY PROFESIONAL PAPER 430-A

Descriptions of 15 species of rugose

and tabulate corals

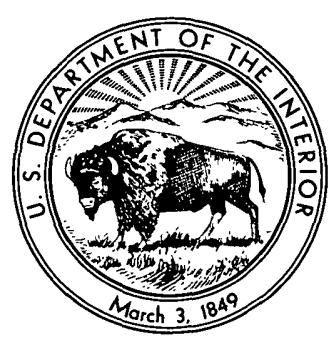




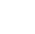





\section{CONTENTS}

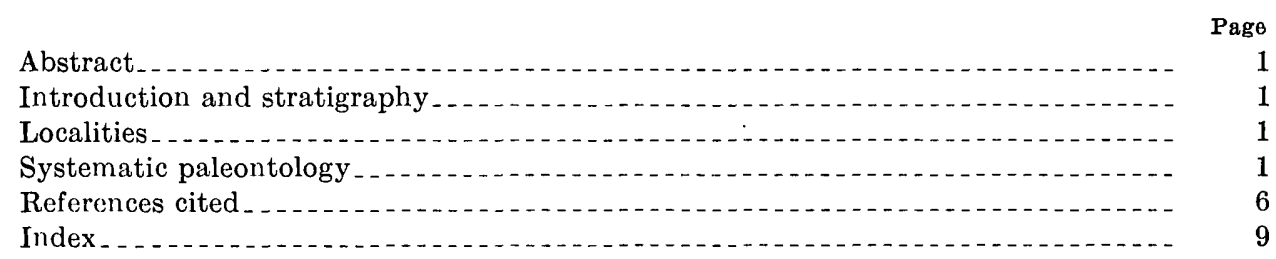

\section{ILLUSTRATIONS}

[Plates follow index]

Plate 1. Phaulactis, Holmophyllum, Entelophyllum, and Spongophylloides.

2. Streptelasma, Cystiphyllum, Ptychophyllum, Entelophyllum, and Tryplasma.

3. Astrocerium, Propora, Arcturia, and Favosites.

4. Heliolites, Cystihalysites, Syringopora, and Plasmopora. 


\title{
SILURIAN CORALS FROM THE MOOSE RIVER SYNCLINORIUM, MAINE
}

\author{
By Erwin C. Stumm
}

\begin{abstract}
The corals, most of which were collected by A. J. Boucot, are from rocks of Silurian and Silurian(?) age in the Moose River synclinorium of northern Maine and in the adjacent border of Quebec. Most of the fossils were collected from outcrops occurring in Somerset, Franklin, and Piscataquis Counties, Maine. A few are from St. Joseph Seigniory, Quebec. The corals were collected from the Hardwood Mountain and Lobster Lake formations in northern Maine and from the Cranbourne limestone in adjacent Quebec. New species of the rugose coral genera Entelophyllum, Holmophyllum, and Tryplasma are described and illustrated. Unidentified species of Streptelasma, Cystiphyllum, Entelophyllum, Phaulactis, and Spongophylloides are illustrated. New species of the tabulate coral genera Arcturia, Astrocerium, Cystihalysites, Heliolites, Plasmopora, Propora, and Syringopora are described. Specimens of Favosites niagarensis Hall are illustrated. The corals are of upper Wenlock or lower Ludlow age.
\end{abstract}

\section{INTRODUCTION AND STRATIGRAPHY}

Corals herein described were largely collected by A. J. Boucot, of the U.S. Geological Survey, during detailed stratigrapbic studies of the Moose River synclinorium, which is in Somerset, Franklin, and Piscataquis Counties of northern Maine. A few of the described specimens were collected by E. S. C. Smith, of Union College, Schenectady, N.Y.

A preliminary account of the stratigraphy by Boucot has been published (Boucot, 1961), and a paper on Devonian corals of the Moose River synclinorium, by W. A. Oliver, Jr. (1960), is now in print. During the course of Boucot's fieldwork between 1951 and 1955 the writer was invited by the Survey to participate in coral studies which led to the present contribution.

Corals from 3 formations at 6 localities were studied. The corals from the Lobster Lake formation at the nortbeast end of the Moose River synclinorium compared with those from the Hardwood Mountain formation at the southwest end of the synclinorium indicate that the formations are of equivalent age. The relationship of these formations to the Cranbourne limestone is not clear, but on the basis of the coral fauna they are approximately of the same age.

All the Silurian corals studied are in fine-grained dense limestones. They do not weather out; so external structures are unknown. All descriptions and determinations are based on thin sections that show internal structures.

\section{LOCALITIES}

U.S.G.S. Description

1417-SD. Lobster Lake formation, Lobster Lake, Piscataquis County, Maine.

2728-SD. Hardwood Mountain formation; north ninth of Spencer quadrangle, in southeast corner 0.6 mile S. $83^{\circ}$ E. east of the top of 2,160 foothill, Somerset County, Maine.

2822-SD. Hardwood Mountain formation, central ninth of Attean quadrangle, on north shore of Little Big Wood Pond, about 0.25 mile southeast of Fox's Camp, Somerset County, Maine.

3400-SD. Lobster Lake formation, east ninth of North East Carry quadrangle at Sunset Point on Lobster Lake, Piscataquis County, Maine.

3484-SD. Hardwood Mountain formation, southeast ninth of Chain Lakes quadrangle, on east boundary of the ninth, on shore of Jim Pond, 1.33 miles north of the south boundary of the northeast ninth, Franklin County, Maine.

3488-SD. Hardwood Mountain formation, central ninth of Spencer quadrangle, on east shore of Baker Pond, N. $94^{\circ}$ E. from the outlet of Davis Pond, Somerset County, Maine.

3496-SD. Hardwood Mountain formation, central ninth of Spencer quadrangle, on the west branch of Spencer Stream, 0.14 mile upstream from the $1,320-\mathrm{ft}$ contour, Somerset County, Maine.

3611-SD. Cranbourne limestone, Range St. Thomas, St. Joseph Seigniory, Quebec.

\section{SySTEMATIC PALEONTOLOGY}

$$
\begin{gathered}
\text { Phylum COELENTERATA } \\
\text { Class ANTHOZOA } \\
\text { Order RUGOSA }
\end{gathered}
$$

Suborder STREPTELASMATINA

Superfamily ZAPHRENTICAE

Family STREPTELASMATIDAE Nicholson and Lydekker

\section{Genus STREPTELASMA Hall}

Streptelasma, Hall, 1847, p. 17, 49, 66-71.

Type species-Streptelasma corniculum Hall (1847, p. 69 , pl. 25, figs. $1 \mathrm{a}-\mathrm{d}$ ). 


\section{Streptelasma? sp. A}

Plate 2, figure 1

Description.-A single transverse section of a specimen indicates that it belongs in this genus. Maximum diameter of section, $22 \mathrm{~mm}$. Septa 86 , all thickened in marginarium to form a peripheral stereozone ranging in thickness from 2 to $3 \mathrm{~mm}$. Major septa extend to axis becoming twisted and possibly forming an axial stereozone. Minor septa about one-third as long as major. Tabulae unknown. Dissepiments apparently absent.

Occurrence: Silurian, Cranbourne limestone; USGS loc. 3611-SD. Figured specimen: USNM 139427.

\section{Streptelasma? sp. B}

Plate 2, figures 12,13

Description.-Two transverse sections are illustrated. The corallite averages about $18 \mathrm{~mm}$ in diameter in the vicinity of the calyx. In one section (fig. 12) cut just above the base of the calyx, septa 64 form a peripheral stereozone averaging $3 \mathrm{~mm}$ in diameter. Major septa extend about two-thirds distance to axis; minor septa not extending beyond stereozone. All septa greatly thickened and in lateral contact peripherally; major septa taper axially. All septa with an axial plate surrounded by stereoplasm. Figure 13 is a section of the same corallite cut through the calyx. Tabulae unknown, dissepiments apparently absent.

Remarks.-The species may belong in the genus Brachyelasma.

Occurrence: Silurian, Hardwood Mountain formation; USGS loc. 3484-SD.

Figured specimen: USNM 139428.

\section{Streptelasma? sp. C \\ Plate 2, figures 6-8}

Description.-Corallum ceratoid, external structures unknown. In two transverse sections diameters range from 10 to $14 \mathrm{~mm}$. Septa average about 60; major thin, extend almost to axis, many irregularly twisted in their axial parts; minor thin and very short, appearing as peripheral ridges less than $0.5 \mathrm{~mm}$ long.

In longitudinal section tabulae are thin, complete or incomplete, relatively widely spaced, irregularly sinuous.

Occurrence: Silurian, Lobster Lake formation; USGS loc. 1417-SD.

Figured specimen: USNM 139429.

\section{Family HALLIIDAE Chapman}

Genus PHAULACTIS Ryder

Phaulactis Ryder, 1926, p. 392.

Lykophyllum Wedekind, 1927, p. 68, 71.

Lykocystiphyllum Wedekind, 1927, p. 69, 73.
Semaiophyllum Vollbrecht in Wedekind, 1927, p. 12, 70-71.

Hercophyllum Jones, 1936, p. 53.

Type species.--Phaulactis cyathophylloides Ryder (1926, p. 392 , pl. 12, fig. 1). Silurian, Slite marl, Wenlock?; Västergarn, Island of Gotland, Sweden.

For generic diagnosis, see Ryder (1926), p. 392.

Phaulactis sp. A

Plate 1, figures 1, 2

Description.--Exterior of corallum unknown. Diameters of two serial transverse sections of figured specimen $25 \mathrm{~mm}$. In transverse sections septa about 84 , major extend to axis, minor about two-thirds as long. Septa in cardinal quadrants dilated in periaxial and axial regions. Tabulae apparently complete and incomplete, closely set. Dissepiments numerous.

Remarks.-The species is considerably larger than the type species $P$. cyathophylloides and has a better developed area of septal dilation in the cardinal quadrants.

Occurrence: Silurian, Cranbourne limestone; USGS loc. 3611-SD.

Figured specimen: USNM 139430.

Family ARACHNOPHYLLIDAE Dybowski

Genus ENTELOPHYLLUM Wedekind 1927

Entelophyllum Wedekind, 1927 , p. 22-24

Xylodes, Lang and Smith, 1927, p. 457, 461 (not Xylodes Waterhouse, 1876).

Type species.-Madeporites articulatum (Wahlenberg).

Entelophyllum parvum n. sp.

Plate 2, figures 9-11

Description.-Corallum phaceloid with cylindrical individual corallites having diameters ranging from 4 to $6 \mathrm{~mm}$. External characteristics unknown. Transverse sections show from 34 to 40 thin radially arranged relatively straight noncarinate septa extending from the periphery. Major septa extend to or nearly to axis; minor septa about one-half as long. No modifications of protosepta present. In longitudinal section tabularium divided into axial area composed of relatively horizontal complete and incomplete tabulae and a periaxial area composed of closely set proximally convex tabulae. Both sets of tabulae relatively evenly spaced at about $0.3 \mathrm{~mm}$ apart. Dissepimentarium composed of 2 or 3 rows of relatively small axially convex dissepiments.

Remarks.-The species differs from E. eruciforme (Davis) from the Louisville limestone of Indiana and 
Kentucky by the lack of numerous connecting talons between corallites and by having more clearly defined axial and periaxial tabulate areas.

Occurrence: Silurian, Hardwood Mountain formation; USGS loc. 2822-3-SD.

Type: Holotype USNM 139431.

\section{Entelophyllum sp. A}

Plate 1, figures 6-8

Description.-Corallum probably phaceloid, composed of cylindrical corallites ranging in diameter from 12 to $14 \mathrm{~mm}$. External features unknown. In transverse section septa thin, ranging from 54 to 60 , major extend to axis and minor terminate at inner margin of dissepimentarium. All septa with small offset spinose carinae across the dissepimentarium. A tangential longitudinal section shows a peripheral dissepimentarium composed of several rows of small dissepiments and the intercepted ends of the carinate septa. Tabulae unknown.

Remarks.-The species is similar to the European species E. pseudodianthus (Weissermel), but has fewer septa and shorter minor septa.

Occurrence: Silurian, Hardwood Mountain formation, USGS loc. 3484-SD.

Figured specimens: USNM 139432 to 139434.

\section{Genus PTYCHOPHYLLUM Edwards and Haime}

Ptychophyllum Edwards and Haime, 1850, p. 69.

Type species.-Ptychophyllum stakesi Edwards and Haime (1850, p. 67 ; 1851, p. 407).

\section{Ptychophyllum sp. A}

Plate 2, figures $3-5$

Description.-Three transverse sections of two specimens show typical characters of species of this genus by having long septa which break up peripherally and which form an axial whorl. Septa thin, and average 56 in number; major septa extend to axis becoming thicker in tabularium and forming a distinct axial whorl. Minor septa also thickened in tabularium and about three-fourths as long as major. All septa become thin, discontinuous, and degenerate in the peripheral part of the dissepimentarium. A long, very narrow fossula extends from the periphery to the axis. Tabulae and dissepiments both present, but their distribution is unknown.

Remarks.-The sections are similar to those of the genotype species $P$. stokesi, and the Maine species may be conspecific with it.
Occurrence: Silurian, Hardwood Mountain formation; USGS loc. 3484-SD; Cranbourne limestone; USGS loc. 3611-SD.

Figured specimens: USNM 139435, 139436.

\section{Suborder COLUMNARIINA \\ Family PTENOPHYLLIDAE Wedekind \\ Genus SPONGOPHYLLOIDES Meyer}

Spongophylloides Meyer, 1881, p. 109.

Actinocystis Lindstrom 1882, p. 21; Wedekind 1927, p. 44.

Type species.-Spongophylloides schumanni Meyer (1881, p. 109, pl. 5, figs. $12-12 \mathrm{c}=$ Cystiphyllum grayi Edwards and Haime, 1851, p. $465 ; 1855$, p. 297 , pl. 72, fig. 3). Silurian, Wenlock, England, and western Europe.

\section{Spongophylloides sp. A \\ Plate 1, figure 9}

Description.-Exterior of corallum unknown, transverse section averaging $15 \mathrm{~mm}$ in diameter. Peripheral one-third of corallum composed of lonsdaleioid dissepimentarium. Dissepiments large, axially convex. About 60 thin radially arranged septa present from inner margin of lonsdaleioid dissepimentarium and extend almost to axis. No modifications of protosepta present. Tabulae apparently numerous and incomplete.

Occurrence: Silurian, Hardwood Mountain formation; USGS loc. 3484-SD.

Figured specimen: USNM 139437.

\section{Family CYSTIPHYLLIDAE Edwards and Haime}

\section{Genus CYSTIPHYLIUM Lonsdale}

Cystiphyllum sp. A

Plate 2, figure 2

Remarks. - A single transverse section is referred to a species of this genus. It is $15 \mathrm{~mm}$ in maximum diameter. The dissepiments and tabellae are large. Traces of degenerate acanthine septa are present.

Occurrence: Silurian, Lobster Lake formation; USGS loc. 1417-SD.

Figured specimen: USNM 139438.

\section{Genus HOLMOPHYLLUM Wedekind}

Holmophylium Wedekind, 1927, p. 31, pl. 4, figs. 6-8; pl. 29, fig. 16.

Diagnosis.-Simple, ceratoid or trochoid rugose corals with relatively short radially arranged acanthine septa. Dissepimentarium wide, composed of small dissepiments. Tabulae, typically complete, widely spaced, proximally convex.

Type species.-Holmophyllum holmi Wedekind (1927, p. 31 , pl. 4, figs. $6-8$; pl. 29, fig. 16). Silurian, Gotland, Sweden. 
Holmophyllum pseudocarinatum n. sp.

Plate 1, figures 3-5

Description.-Exterior of corallum unknown; shape apparently ceratoid with maximum diameter of $22 \mathrm{~mm}$. In transverse section septa acanthine, about 100, radially arranged, with no modifications of protosepta. All septa of same length extend distally and axially to inner margin of dissepimentarium, about $1 / 2$ to $2 / 3$ the distance to axis. In longitudinal section dissepimentarium averaging $5 \mathrm{~mm}$ wide, composed of small distally and axially convex dissepiments. Tabularium average $5 \mathrm{~mm}$ wide, composed of relatively widely spaced complete and incomplete proximally convex tabulae.

Remarks.-This is the first species of the genus described from North America. It differs from the genotype species by having more closely set tabulae, a wider dissepimentarium, and more closely crowded acanthine septa.

Occurrence: Silurian, Hardwood Mountain formation; USGS loc. 2822-SD.

Type: Holotype USNM 139439.

\section{Family TRYPLASMATIDAE Etheridge}

\section{Genus TRYPLASMA Lonsdale}

Tryplasma Lonsdale, 1845, p. 613.

Pholidophyllum Lindstrom, 1871 , p. 925.

Stortophyllum Wedekind, 1927, p. 30-31.

Acanthodes, Dybowski, 1873, p. 334, 364 (not Acanthodes Agassiz, 1833).

Spiniferina Penecke, 1894, p. 592.

Type species.-Tryplasma aequabile Lonsdale (1845, p. 613, 633, pl. A, figs. 7-7a). Silurian, England, western Europe, and Russia.

\section{Tryplasma nordica $\mathbf{n}$. sp.}

Plate 2, figures 14-16

Description.-Coralla simple, ceratoid, averaging about $3 \mathrm{~cm}$ long and $1.5 \mathrm{~cm}$ in maximum diameter. External features unknown. In transverse section septa 50 to 60 , acanthine, appearing as peripheral ridges 1 to $2 \mathrm{~mm}$ long and becoming discontinuous periaxially. In longitudinal section acanthine septa well shown as upward and inward projecting vertical rows of spines extending 1 to $1.5 \mathrm{~mm}$ inward from the peripheral ridges. Tabulae typically horizontal, mostly complete, a few incomplete, spaced at an average distance of a little less than $2 \mathrm{~mm}$ apart.

Remarks. -The species is most nearly related to $T$. radicula (Rominger), but it has longer septal spines and more widely spaced tabulae.

Occurrence: Silurian, Lobster Lake formation; USGS loc. 1417-SD.

Types: Holotype USNM 139440; paratype USNM 139441.

\section{Order TABULATA \\ Family HELIOLITIDAE Lindstrom \\ Genus PROPORA Edwards and Haime}

Propora Edwards and Haime, 1849, p. 262; 1850, p. 59; Nicholson, 1879, p. 247.

Lyellia Edwards and Haime, 1851, p. 150, 226; Rominger, 1876, p. 15; Nicholson, 1879, p. 249.

PPinacopora Nicholson and Etheridge, 1878, p. 52; Nicholson, 1879, p. 250.

Types species.-Porites tubulatus Lonsdale (1839, p. 687, pl. 16, figs. 3-3b). Silurian, Wenlock, England, and western Europe.

\section{Propora nordica n. sp.}

Plate 3, figures 5, 6

Description.-Exterior of corallum unknown. In transverse section tabularia circular, ranging in diameter from 1.3 to $1.8 \mathrm{~mm}$ and separated by distances ranging from 1.8 to $2.7 \mathrm{~cm}$. Interior of each tabularium with 12 vertical rows of very short septal spines ranging in length from 0.2 to $0.5 \mathrm{~mm}$. Spaces between tabularia occupied by elongate dissepiments.

In longitudinal section tabularia with horizontal typically complete tabulae ranging from 0.5 to $1.3 \mathrm{~mm}$ apart. Intertabulate areas composed of elongate distally convex dissepiments.

Remarks.-This species resembles the type species $P$. tubulata in size of tabulate areas, but it has much shorter septal spines. In the intertabulate areas the dissepiments of $P$. tubulata are much smaller and irregularly spaced. $P$. nordica differs from $P$. glabra (Owen), commonly known as Lyellia americana Edwards and Haime, by having much shorter septa and more widely spaced tabulae.

Occurrence: Silurian, Cranbourne limestone; USGS loc. 3611SD.

Type: Holotype, USNM 139442.

\section{Genus PLASMOPORA Edwards and Haime}

Plasmopora Edwards and Haime, 1849, p. 262; 1851, p. 221; Nicholson, 1879, p. 245.

Type species.-Porites petalliformis Lonsdale (1839, p. 687, pl. 16, figs. 4-4a). Silurian, Wenlock, England, and western Europe.

Plasmopora franklinensis n. sp.

Plate 4, figures 8,9

Description.-Exterior of corallum unknown. In transverse section corallites with tabulate areas circular to subcircular, ranging from 1.5 to $2.2 \mathrm{~mm}$ apart and separated by distances ranging from 2.4 to $4.2 \mathrm{~cm}$. Twelve septa extend inward from wall of tabularium and also outward across intertabulate areas to join 
septa from neighboring tabulate areas. Within tabulate areas septa composed of vertical rows of spines 0.2 to $0.5 \mathrm{~mm}$ long. Between tabulate areas septa lamellar, forming a weblike network. In longitudinal section tabulate areas composed of horizontal complete tabulae ranging from 0.2 to $1 \mathrm{~mm}$ apart. Between tabulate areas exsert septa appear as vertical ridges separated by closely set horizontal or cystose dissepiments.

Remarks.-This species differs from the type species $P$. petalliformis (Lonsdale) from the Wenlock of Great Britain and Gotland by having much shorter septal spines and a different dissepimental arrangement. In $P$. petalliformis the dissepiments between the exsert septa are all of the globose type whereas in $P$. franklinensis most of them form short horizontal bars. $P$. franklinensis is distinguished from the common North American species $P$. follis in having the tabulate areas approximately twice as wide.

Occurrence: Silurian, Hardwood Mountain formation; USGS loc. 3484-SD.

Type: Holotype USNM 139443.

\section{Subfamily Heliolitidae}

\section{Genus HELIOLITES Dana}

Heliolites Dana, 1846, p. 541.

Type species.-Astrea porosa Goldfuss (1826, p. 64, pl. 21, fig. 7). Devonian, Eifel.

Heliolites interstinctus occidentalis n. subsp.

Plate 4, figures 1,2

Description.-Corallum probably hemispherical, composed of circular tabulate areas surrounded and separated by tubuli. Tabulate areas range in diameter from 0.9 to $1.2 \mathrm{~mm}$ and range from $1.5 \mathrm{~mm}$ to a maximum of $2.9 \mathrm{~mm}$ apart. In lateral section each tabulate area shows 12 very short septal ridges. Tubuli range in diameter, from 0.25 to $0.3 \mathrm{~mm}$, between 6 and 10 tubuli present in a line between adjacent tabulate areas. In longitudinal section tabulae complete, horizontal, relatively evenly spaced at an average distance of 0.4 $\mathrm{mm}$ apart, a few spaced as much as $0.8 \mathrm{~mm}$ apart.

Remarks.-The subspecies is similar to typical $H$. interstinctus except for the spacing of the tabulae. In $H$. interstinctus the tabulae are very closely set, averaging $0.2 \mathrm{~mm}$ apart.

Occurrence: Silurian Hardwood Mountain formation; USGS loc. $3496-\mathrm{SD}$.

Type: Holotype USNM 139444.

\section{Family FAVOSITIDAE Lomarck}

\section{Genus ASTROCERIUM Hall}

Astrocerium Hall, 1851, p. 399; 1852, p. 120.

Type species.-Astrocerium venustum Hall (1852, p. 120-121, pl. 34, figs. 1a-j).
Remarks.-This genus has been merged with Favosites by most authors. I feel that the rows of septal spines present in species of Astrocerium are a character sufficient to separate the genus from Favosites.

Astrocerium intermittens n. sp.

Plate 3, figures 1,2

Description.-Corallum massive, hemispherical, composed of cerioid corallites ranging in diameter from 1 to $1.5 \mathrm{~mm}$. In a few corallites 12 vertical rows of septal spines are present; the spines extend from $1 / 2$ to $2 / 3$ the distance to the axis. In most of the corallites only a few of the septal spines are present, and in some more are present. In longitudinal sections tabulae are complete, horizontal, relatively evenly spaced from 0.3 to $0.5 \mathrm{~mm}$ apart. Mural pores uniserial, spaced about $0.5 \mathrm{~mm}$ apart in vertical series. Intermittently developed septal spines can be seen directed obliquely upward in some corallites.

Remarks.-This species differs from both $A$. venustum Hall and $A$. hisingeri (Edwards and Haime) by the intermittent development of the septal spines.

Occurrence: Silurian, Hardwood Mountain formation; USGS loc. $3484-\mathrm{SD}$.

Type: Holotype USNM 139445.

Astrocerium intermittens magnum n. subsp.

Plate 3, figures 3,4

Description.-Corallum similar to typical $A$. intermittens except that corallites are larger, ranging in diameter from 1.6 to $2.3 \mathrm{~mm}$ and that the septal spines are shorter and more numerous, though still intermittently developed. Septal spines typically about 0.1 $\mathrm{mm}$ long. The tabulae in the subspecies are more irregularly spaced, in some places as much as $1.2 \mathrm{~mm}$ apart.

Occurrence: Silurian, Hardwood Mountain formation; USGS loc. 2728-SD.

Type: Holotype, USNM 139446.

Genus FAVOSITES Lamarck

Favosites Lamarck, 1816, p. 204.

Type species.-Favosites gothlandica Lamarck (1816, p. 205).

\section{Favosites niagarensis Hall}

Plate 3, figures 9,10

Favosites niagarensis Hall, 1852, p. 125, pl. 34A, figs. 4a-i.

Description.-Corallum -massive hemispherical, corallites cerioid, mature areas ranging in diameter from 1.3 to $1.6 \mathrm{~mm}$ interspersed with a few of much smaller size. Mural pores uniserial. Tabulae complete, typi-

$6246490-62-2$ 
cally horizontal, a few concave, ranging from 0.4 to $1.3 \mathrm{~mm}$ apart.

Remarks.-The measurements of the corallum fall within the range of those of typical $F$. niagarensis from the Lockport dolomite of New York.

Occurrence: Silurian, Hardwood Mountain formation; USGS loc. 3488-SD.

Types: Hypotypes USNM 139447, 139448.

\section{Family HALYSITIDAE}

\section{Genus ARCTURIA Wilson}

Arcturia Wilson, 1931, p. 294.

Type species.-Arcturia complexa Wilson (1931, p. 295, pl. 3, figs. 1-3).

Diagnosis.-Massive hemispherical tabulate corals with phaceloid corallites which may be trigonal, tetragonal, or subrounded and which are connected by hollow horizontal tubules.

\section{Arcturia angularis n. sp.}

Plate 3 , figures 7, 8

Description.-Growth form probably hemispherical. In transverse section corallites phaceloid, trigonal, tetragonal, or subrounded, ranging in diameter from 0.3 to $0.5 \mathrm{~mm}$ and separated by distances ranging from 0.2 to $1.0 \mathrm{~mm}$ apart. Corallites connected by horizontal cylindrical tubules that occur in vertical rows with intervals averaging $0.2 \mathrm{~mm}$ between individual tubules. In longitudinal section cut tubules appear as large mural pores. Tabulae complete, very thin, typically horizontal, a few concave, ranging from 0.3 to $0.4 \mathrm{~mm}$ apart.

Remarks.- The type species is reported as having no tabulae preserved. The illustrations of $A$. complexa show that the corallites are smaller than those of A. angularis.

Occurrence: Silurian, Hardwood Mountain formation; USGS loc. $3484-\mathrm{SD}$.

Type: Holotype, USNM 139449.

\section{Genus CYSTIHALYSITES Tchernychev}

Cystihalysites Tchernychev, 1941, p. 70.

Type species.-By original designation Cystihalysites mirabilis Tchernychev (1941, p. 70-71, pl. 2, figs. 5-7; pl. 3, figs. 1-6).

\section{Cystihalysites sp. ef. C. amplitubulata (Lambe)}

Plate 4, figures 3-5

Description.-Corallum probably hemispherical, composed of relatively long ranks of corallites. Ranks composed of 2 to 10 oval macrocorallites ranging from
1.5 to $2.5 \mathrm{~mm}$ in larger diameter and averaging about $1.5 \mathrm{~mm}$ in smaller diameter. Between each macrocorallite is a subpolygonal microcorallite less than $1 \mathrm{~mm}$ in diameter. No septal spines or ridges present in either macrocorallites or microcorallites. In longitudinal section tabulae in macrocorallites typically complete and horizontal, spaced from 0.15 to $0.8 \mathrm{~mm}$ apart. Tabulae in microcorallites broken up into cystose, distally convex tabellae.

Remarks.- In all specimens seen, most of the microcorallites have been filled in with secondary deposits so that the areas between the macrocorallites appear as solid sclerenchyme in transverse section. Traces of the cystose tabellae of the microcorallites can be seen in a few longitudinal sections (pl. 4, fig. 5).

The species is similar to typical $C$. amplitubulata (Lambe), but differs by the smaller size of the microcorallites. In $C$. amplitubulata the microcorallites equal or exceed the size of the macrocorallites.

Occurrence: Figured specimens-Silurian, Hardwood Mountain formation; USGS loc. 3496-SD; Lobster Lake formation, USGS loc. $3400-\mathrm{SD}$.

Figured specimen: USNM 139450, 139451.

\section{Genus SYRINGOPORA Goldfuss}

Syringopora, Goldfuss, 1826, p. 75.

Type species.-Syringopora ramulosa Goldfuss (1826, p. 76 , pl. 25, fig. 7).

\section{Syringopora multitubulosa n. sp.}

Plate 4, figures 6,7

Description.-Corallum phaceloid, composed of cylindrical corallites averaging $1.5 \mathrm{~mm}$ in diameter. Corallites connected by relatively closely spaced transverse tubuli, spaced, in parts of corallum, from 1 to $2 \mathrm{~mm}$ apart. Corallites separated by distances ranging from 1.7 to $4.2 \mathrm{~mm}$ apart. Corallite walls $0.2 \mathrm{~mm}$ thick. Interior of corallite walls provided with 12 vertical rows of very short septal spines. Spines irregularly developed, one or two in a corallite being larger than the others. In some corallites not all rows of spines developed. Also present on interior of corallites are elongate dissepiments extending from the periphery on all sides to produce a narrow axial tube.

Remarks.-The species differs from $S$. maclurii Billings by the more complicated internal structures.

Occurrence: Silurian, Hardwood Mountain formation; USGS loc. $3484-\mathrm{SD}$.

Type: Holotype USNM 139452.

\section{REFERENCES CITED}

Boucot, A. J., 1961, Stratigraphy of the Moose River synclinorium, Maine: U.S. Geol. Survey Bull. 1111-E, p. 153-188.

Dana, J. D., 1846, Zoophytes in United States exploring expedition, during the years $1838,1839,1840,1841,1842$, under the command of Charles Wilkes, U.S.N.: v. 7, 740 p. 
Dybowski, W. N., 1873, Monographie der Zoantharia sclerodermata rugosa Silurformation Estlands, Nord-Livlands und der Insel Gotland: Archiv. Naturkunde Liv-, Est- und Kurlands, ser. 1, v. 3, p. 257-532.

Edwards, H. M., and Haime, Jules, 1849, Mémoire sur les Polypiers appartenant aux groupes naturels des Zoathaires perforés et des Zoanthaires tabulés: Acad. sci. [Paris] Comptes rendus, v. 24, p. 257-263.

1850, A monograph of the British fossil corals; Pt. 1, Introduction: Paleont. Soc. London Mon., v. 3, 71 p.

1851, Monographie des Polypiers fossiles des Terrains palaeozoïques: Mus. Nat. History Paris Archives, v. 5, $502 \mathrm{p}$.

- 1855, A monograph of the British fossil corals; Pt. 5, Corals from the Silurian formation: Paleont. Soc. London Mon., p. 245-299.

Goldfuss, G. A., 1826-33, Petrefacta Germaniae, v. 1, 240 p., Düsseldorf.

Hall, James, 1847, Paleontology of New York, v. 1, 252 p.

1847, Descriptions of the organic remains of the lower division of the New York system, v. 1 of Paleontology of New York: Albany, New York, Van Benthuysen, 338 p.

1852, Descriptions of the organic remains of the lower middle division of the New York system, v. 2 of Paleontology of New York: Albany, New York, Van Benthuysen, 362 p.

Jones, O. A., 1936, On the Silurian Corals Cyathophyllum shearbyi and Heliophyllum yassense: Queensland Mus. Mem., v. 11 , p. $53-58$.

Lamarck, J. B. P. A. de M, 1816, Histoire naturelle des Animaux sans Vertèbres: Paris, v. 2, 568 p.

Lang, W. D., and Smith, Stanley, 1927, A critical revision of the rugose corals described by William Lonsdale in Murchison R. I., Silurian System: Geol. Soc. London Quart. Jour., v. 83 , p. $448-491$, pls. $34-37$.
Lindström, Gustav, 1871, Om operkularbildningen hos några nutida och siluriska koraller: Köngl. Vetensk.-Akad. Öfvers., Förhandl., v. 27 (for 1870), p. 921-926.

- 1882, Anteckningar om silurlagren på Calsöarne: Köngl. Vetensk.-Akad. Öfvers., Förhandl., v. 39 (for 1882), p. 5-30.

Lonsdale, William, 1839, Corals in Murchison, R. I., Silurian System: London, p. 675-699.

- 1845, Description of some Palaeozoic corals of Russia, pt. 1 of Murchison, R. I., de Verneuil, E., and von Keyserling, A., the geology of Russia in Europe and the Ural Mountains: London, John Murray, v. 1, p. 591-534.

Meyer, Georg, 1881, Rugose Korallen als ost-und westpreussische Diluvialgeschiebe: Phys. Gesellsch. Königsberg Schrift., v. 22 , p. $97-110$.

Nicholson, H. A., 1879, On the structure and affinities of the "Tabulate corals" of the Palaeozoic period:Edinburgh and London, William Blackwood \& Sons, 342 p.

Nicholson, H. A., and Etheridge, Robert, 1878, A. Monograph of the Silurian fossils of the Girvan district in Ayrshire: Edinburgh and London, William Blackwood \& Sons, v. 1, p. 1-135.

Oliver, W. A., Jr., 1960, Devonian rugose corals from northern Maine: U.S. Geol. Survey Bull. 1111-A, p. 1-23, pls. 1-5.

Penecke, K. A., 1894, Das Grazer Devon: K.-k. Geol. Reichanst. Jahrb., (Jahrg. 1893), v. 43, p. 567-616, pls. 7-12.

Rominger, Carl, 1876, Fossil corals: Michigan Geol. Survey, v. 3, pt. 2, $161 \mathrm{p}$.

Ryder, T. A., 1926, Pycnactis, Mesactis, Phaulactis, gen. nov., and Dinophyllum Lind.: Annals and Mag. Nat. History, ser. 9 , v. 18 , p. 385-401, pls. 9-12.

Tchernychev, B. B., 1941, Vsesoyuznyy arkticheskiy institut Trudy, v. 158, p. 65-74 (not seen).

Wedekind, Rudolf, 1927, Die Zoantharia Rugosa von Gotland (bes. Nordgotland): Sveriges Geol. Undersökning, ser. Ca, v. 19 , p. 1-94.

Wilson, A. E., 1931, Notes on the Baffinland fossils: Royal Soc. Canada Trans., 3d ser., v. 25, sec. 4, p. 285-306. 



\section{INDEX}

[Italic numbers inđicate descriptions]

\begin{tabular}{|c|c|}
\hline Page & Page \\
\hline equabile, Tryplasma... & maclurii, Syringopora............ \\
\hline mericana, Lyellia......... & Madeporttes articulatum \\
\hline mplitubulata, Cystihalysates & magnum, Astrocerium intermittens....... \\
\hline ngularis, Arcturia.......... & 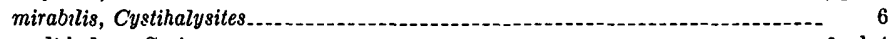 \\
\hline 4rcturia...................... & multibulosa, Syringopora... \\
\hline $6 ; \mathrm{pl} .3$ & \\
\hline- & niagarensis, Favosites............... \\
\hline deporites. & ordica, Propora \\
\hline orosa ............... & Tryplasma \\
\hline$u m$ & \\
\hline -.--.- & , Heliolites interstinct \\
\hline $\begin{array}{r}\text { intermittens } \\
\quad \text { magnum. }\end{array}$ & parvum, Entelophyllum_.-...- \\
\hline$u m$. & pettaliformis, Porites.......... \\
\hline & - \\
\hline 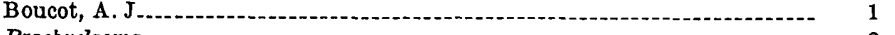 & cyathophylloides............ \\
\hline Brachyelasma.................. & sp. A \\
\hline complexa, Arcturia......... & 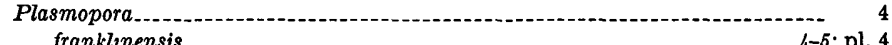 \\
\hline otelasma & $\begin{array}{l}\text { franklinensis............-. } \\
\text { Porites follis }\end{array}$ \\
\hline Cranbourne limestone, Quebec. & perites follis...................... \\
\hline cyathophylloides, Phaulactis.... & latus \\
\hline Cystihalysites............-. & porosa, Astrea.......... \\
\hline amplitubulata.--.------- & 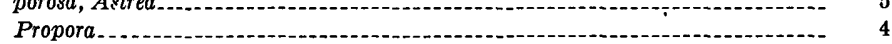 \\
\hline mirabilis-10-10 6 & 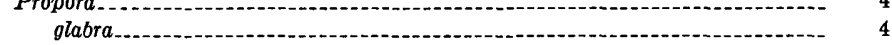 \\
\hline $\mathrm{sp}_{2}$ & $4 ; \mathrm{pl} .3$ \\
\hline Cystiphyllum grayi....---..... & a........-...-. \\
\hline sp. A. & 3 \\
\hline ing & ;; pl. 1 \\
\hline Entelophyllum & 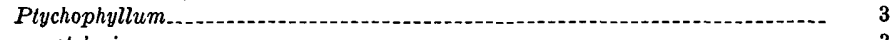 \\
\hline$m e \ldots$ & 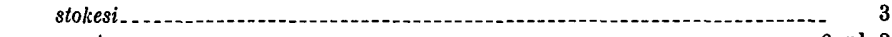 \\
\hline parvum & sp. A \\
\hline pseudodzanthus & \\
\hline Celophyllum & Tryplasma \\
\hline Europe, western & Russla \\
\hline 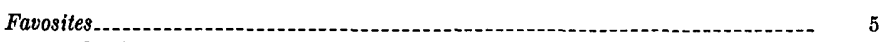 & -..- \\
\hline 5 & $-\cdots$ \\
\hline 5-6; pl. 3 & C........ \\
\hline follis, Porites................... & 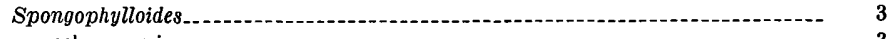 \\
\hline franklinensıs, Plasmopora...... & nni-1.-1 \\
\hline - & hyllum.- \\
\hline eden...-. 3, 5 & Strep \\
\hline grayi, Cystiphyllum..................... & um \\
\hline untain formation, $\mathrm{N}$ & 2; pl. 2 \\
\hline $\begin{array}{ll}5 \\
5\end{array}$ & \\
\hline - 5; pl.4 & 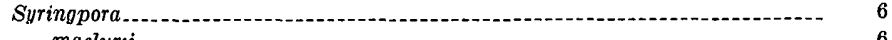 \\
\hline 5 & 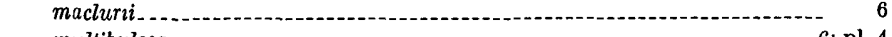 \\
\hline lum.---.-.. & $6 ;$ pl. 4 \\
\hline 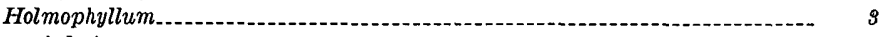 & nulosa............... \\
\hline holmi & -...- \\
\hline alum............ & 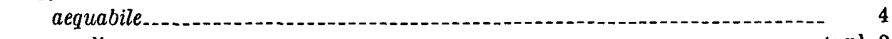 \\
\hline intermittens, Astrocerium... & $4 ; \mathrm{pl}$ \\
\hline $5 ; \mathrm{pl} .3$ & cula \\
\hline $\begin{array}{l}\text { interstinctus, Heliolites................. } \\
\quad \text { occidentalis, Heliolites. }\end{array}$ & , Propora Porites. \\
\hline $1,2,3,4,6$ & 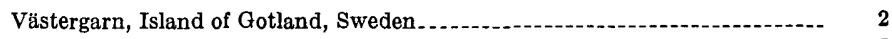 \\
\hline - 6 & venustum, Astrocerium \\
\hline le limestone, Indiana and Kentucky-..- 2-3 & \\
\hline 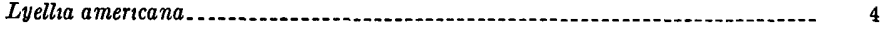 & 2, \\
\hline
\end{tabular}





\section{Silurian Rugose Corals from}

the Lake Témiscouata Area Quebec

By WILLIAM A. OLIVER, JR.

SILURIAN CORALS FROM MAINE AND QUEBEC

GEOLOGICAL SURVEY PROFESIONAL PAPER 430-B

Descriptions of five species representative of the Gotland coral fauna of western Europe

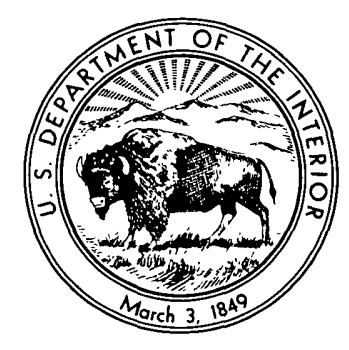



CONTENTS

Abstract.

Introduction

Stratigraphic setting

Localities

Systematic paleontology

Genus Phaulactis Ryder

Genus Tryplasma Lonsdale...

Genus Columnaria Goldfuss _...

Genus Holmophyllum Wedekind

Genus Entelophyllum Wedekind

References cited

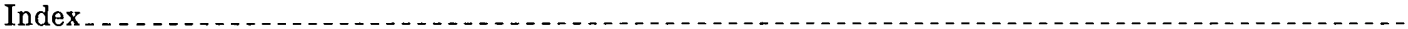

11

11

11

12

12

12

13

14

15

15

16

\section{ILLUSTRATIONS}

[Plates follow index]

Plate 5. Phaulactis quebecensis n. sp. and Holmophyllum sp. 1

6. Phaulactis quebecensis n. sp. and Entelophyllum sp. 1

7. Tryplasma nordica Stumm and Holmophyllum sp. 1

8. Columnaria? coralliferum (Hall)

TABLE

TABLE 1. Described and associated corals 



\title{
SILURIAN RUGOSE CORALS FROM THE LAKE TÉMISCOUATA AREA, QUEBEG
}

\author{
By William A. Oliver, Jr.
}

\begin{abstract}
A new Silurian coral fauna from the Mont Wissick formation, Quebec, is similar to one described from northern Maine by Stumm in chapter A of this paper. Species of Phaulactis, Tryplasma, Holmophyllum, and Entelophyllum are close to or identical with Maine species, and allied to elements of the Gotland (Sweden) coral fauna of western Europe.

Columnaria? coralliferum (Hall) is present in the Mont Wissick formation and in the Cobleskill limestone, at Schoharie, N.Y.

Two species of rugose corals (one new) are described in some detail; three other species are briefly described and illustrated. Associated tabulate corals are listed.
\end{abstract}

\section{INTRODUCTION}

Corals from the Mont Wissick formation in Quebec are similar to those described by Stumm (1962) from the Hardwood Mountain and Lobster Lake formations in Maine. Four of the five rugose genera from the Mont Wissick formation were also described from Maine, and at least two species and possibly four, occur in both areas (see remarks accompanying the descriptions). Comparison of the tabulate coral fauna emphasizes the similarities. Species in 8 genera were described from Maine; species from 9 genera are listed from Quebec; 5 genera and at least 3 species occur in both areas. These comparisons suggest that the Mont Wissick formation is correlative with the Hardwood Mountain and Lobster Lake formations and that the Maine and Quebec areas were part of one faunal province during part of the Middle or Late Silurian. Study of the Quebec corals adds to the paleogeographic picture which resulted from the study of the Moose River synclinorium area, Maine, by Boucot (1961).

The described and listed corals were collected by Dr. Pierre J. Lespérance during fieldwork for the Quebec Department of Mines. I am indebted to Dr. Lespérance and to Dr. Jacques Béland of the Department of Mines, for permission to describe and list the fauna. Thin sections were prepared by William C. Pinckney, Jr.; photographs are by the author.

\section{STRATIGRAPHIC SETTING}

Lespérance (1959) briefly described the lithologic sequence and geographic distribution of the Mont Wissick formation in the Squateck West area, Quebec. Coral collections are from the lower four-fifths $(4,700$ $\mathrm{ft}$ ) of the formation. No corals were seen from the upper 1,300 feet. Table 1 indicates the distribution of the described and associated corals; all assignments of collections to position within the formation are by Lespérance (written communications, 1959, 1960).

Lespérance (1959) assigned a "Silurian (and younger?)" age to the Mont Wissick formation. Earlier, McGerrigle (1934, p. 137) assigned a Devonian(?) age, although both Bailey and McInnes (1888, p. 32-34) and Kindle (1914) considered it Silurian.

The corals clearly indicate a Silurian age for the coralliferous part of the formation. Phaulactis, Holmo-

TABLE 1.-Described and associated corals

\begin{tabular}{|c|c|c|c|c|c|}
\hline & \multicolumn{5}{|c|}{ Unit } \\
\hline & 1 & 2 & 3 & 4 & 5 \\
\hline \\
\hline & \multicolumn{5}{|c|}{$\begin{array}{l}\text { Tryplasma nordica Stumm } \\
\text { Columnaria? coralliferum (Hall) }\end{array}$} \\
\hline \multirow{2}{*}{\multicolumn{6}{|c|}{$\begin{array}{l}\text { Columnaria? coralliferum (Hall) } \\
\text { Holmophyllum sp. } 1\end{array}$}} \\
\hline $\begin{array}{l}\text { Entelophyllum sp. } 1 \\
\text { Cerioid rugose coral }\end{array}$ & & & & & \\
\hline Cerioid rugose coral..... & & $\hat{x}$ & & & $-\cdots-$ \\
\hline \multicolumn{6}{|l|}{ Indeterminate horn corals.... } \\
\hline \multicolumn{6}{|l|}{$\begin{array}{l}\text { Alveolites } \mathrm{sp} \\
\text { Cladopora } \mathrm{sp}\end{array}$} \\
\hline \multicolumn{6}{|l|}{$\begin{array}{l}\text { Favosites } \\
F \text {. sp. aff , , . : . Schuchert }\end{array}$} \\
\hline \multirow{2}{*}{\multicolumn{4}{|c|}{$\begin{array}{l}F . \text { sp. cf. } F \text {, Javosus (Uolatuss) } \\
F \text {. sp. cf. } F \text {, hisingeri } \mathrm{E} \text {. and } \mathrm{H} .\end{array}$}} & $\mid-\cdots$ & $x$ \\
\hline & $x$ & $\hat{x}$ & & & \\
\hline \multicolumn{6}{|l|}{$F$. sp. cf. $F$. occidentalis Hall } \\
\hline \multicolumn{6}{|l|}{ Ramose favositoid } \\
\hline \multicolumn{6}{|l|}{$\begin{array}{l}\text { Paleofavosites sp } \\
\text { Custihalysites sp cf C amplitubulata (Lambe) }\end{array}$} \\
\hline \multicolumn{6}{|l|}{$\begin{array}{l}\text { Cystihalysites sp. cf. C. amplitubulata (Lambe) } \\
\text { Halysites sp. cf. H. nitida Lambe... }\end{array}$} \\
\hline \multicolumn{6}{|l|}{$\begin{array}{l}\text { II. sp } \\
\text { Syringopora sp }\end{array}$} \\
\hline Syringopora sp....... & & $x$ & & $-\cdots$ & (?) \\
\hline \multicolumn{6}{|l|}{ Auloporoid coral } \\
\hline \multicolumn{6}{|l|}{ Heliolites sp ... } \\
\hline \multicolumn{6}{|l|}{$\begin{array}{l}\text { Plasmopora petaliformis (Lonsdale) } \\
\text { Stromatoporoids. }\end{array}$} \\
\hline & & & & & Feet \\
\hline issick formation & & & & & $0-175$ \\
\hline & & & & & \\
\hline 4. Upper lower M & & & & & 4,7 \\
\hline
\end{tabular}


phyllum, Cystihalysites, and Halysites are restricted to the Silurian system and, in addition, Paleofavosites is not known from post-Silurian rocks. Holmophyllum and Entelophyllum are not known from rocks of Llandovery age (Lower Silurian); so presumably the corals are either Wenlock or Ludlow in age. The species to which the Mont Wissick tabulate corals are compared, are from formations in the Chaleurs Bay, Anticosti, Quebec, and eastern New York areas that are of Wenlock and Ludlow age according to A. J. Boucot (oral communication, 1961). The presence of Columnaria? coralliferum (Hall) suggests a relationship with the Cobleskill limestone in eastern New York, also of Ludlow age.

The Mont Wissick brachiopods have been analyzed by Boucot (written communication, 1959) who considers the formation to be of early Ludlow age because of the presence of Conchidium.

The "Silurian (and younger?)" age assignment of the Mont Wissick by Lesperance (1959) is supported by the coral data. The age of the upper part of the formation is not known, but the lower four-fifths is of Niagara or post-Niagara Silurian age.

The Maine fauna described by Stumm in chapter A of this paper is similar to, and probably correlative with, the Mont Wissick fauna bere described. The two areas are nearly 200 miles apart. The Maine and Quebec corals represent the first extensive Gotland-type coral fauna described from North America.

\section{LOCALITIES}

The following fossil localities are shown (without number) on the Quebec Department of Mines Preliminary Map 1273, Squateck Area, West Half, which accompanies Lespérance, 1959. All are in the Mont Wissick formation, unit 3 of Lespérance (1959), except locality 318 which is in unit $3 \mathrm{~A}$.

F1. 0.85 mile N. $31^{\circ}$ E. of the north end of Lake Anna. 41A. 0.4 mile south of north end of Lake Sauvagesse, just east of lake.

F52. Between Lake Sauvagesse and road, 0.15 mile south of northeast corner of lake.

F54. 0.3 mile south of northeast corner of Lake Sauvagesse. F233. 1.65 mile S. $53^{\circ} \mathrm{W}$. of St.-Michel de Squateck.

F300. 1.2 mile S. $75^{\circ} \mathrm{W}$. of north end of Petit Lac Touladi.

318. North shore of Crooked' Lake, 2.35 mile S. $78^{\circ} \mathrm{W}$. of north end of Petit Lac Touladi. (Unit 3A.)

675. 0.2 mile north of the north point of Lake Bédard.

Stratigraphic distribution of collections is as follows (Lespérance, written communication, 1960):
Lower Mont Wissick $\ldots \ldots \ldots$ Upper.

Middle

Loc. F54

$2,500-3,500$

Locs. 41A, F52

Loc. F1 .........

Locs. F300, 675 $\ldots . . . . .6$

Basal

Loc. F233.

$175-2,500$

12,250

11,920

$425-1,650$

${ }^{2} 100-400$

$0-\quad 175$

${ }^{1}$ Approximately.

2 Probably.

\section{SYSTEMATIC PALEONTOLOGY}

\section{Family LYKOPHYLIIDAE}

\section{Genus PHAULACTIS Ryder}

Phaulactis Ryder, 1926, p. 392; Lang and Smith, 1927, p. 457; Smith, 1930, p. 308; Wang, 1950, p. 216; Bulvanker, 1952, p. 26-27; Hill, 1956, p. 272.

Mesactis Ryder, 1926, p. 390.

Hercophyllum Jones, 1936, p. 53; Hill, 1940, p. 402-403.

See Wang, 1950, and Hill, 1956, for synonymy of Wedekind's (1927) genera.

Type species.-Phaulactis cyathophylloides Ryder (1926, p. 392-393, pl. 11 figs. 1-6; pl. 12, fig. 1). Silurian; Slite group (Wenlock). Västergarn, Island of Gotland, Sweden.

Diagnosis.-Small to medium-sized trochoid to cylindrical solitary corals with numerous bilaterally arranged long septa, a wide zone of small arched dissepiments, and closely spaced incomplete arched tabulae. In early stages the septa are dilated and in lateral contact; in later stages the septa attenuate from the periphery, and the final stage may show little or no dilation.

Remarks.-Species of Phaulactis have been described from England, Gotland, the U.S.S.R., China?, and Australia. Hill (1959) reviewed these occurrences and indicated the range of the genus to be from upper Llandovery to middle Ludlow (Aymestry limestone). Bulvanker (1952, p. 3-4) however, indicated an upper Ludlow age for some Phaulactis cyathophylloides in Podolia, U.S.S.R.

Phaulactis quebecensis n. sp.

Plate 5, figures 1-5; plate 6, figures 1-10

Phaulactis sp. A Stumm, 1962 (chapter A of this series).

Diagnosis.-Phaulactis in which septal attenuation tends to start and proceed more rapidly on the counter side, and in which the inner margin of the dissepimentarium is relatively well defined.

External features.-Trochoid, ceratoid, and subcylindrical corals of small to medium size. Maximum diameter varies from 12 to $30 \mathrm{~mm}$, length from 25 to $75 \mathrm{~mm}$. Exteriors poorly preserved, generally smooth except for a few coarse angular rugae on the larger specimens. Calice deep, V-shaped, with major septa 
projecting slightly on all sides; fossula formed in lower part of calice by a short cardinal septum.

Internal features.-Septa bilaterally arranged, pinnate near the cardinal septum, mostly radial in the alar and counter areas. Major septa long, extending not quite to the axis and forming no axial structure; the ephebic stages of 7 individuals show 29 to 45 major septa in transverse sections of 13 to $22 \mathrm{~mm}$ diameter. Minor septa extend less than half the distance to the axis; they average two-fifths the length of the major septa and are nearly as thick. Cardinal septum short; adjacent major septa are successively longer and pinnately arranged with respect to the cardinal-counter plane. Septal dilation is more general in cardinal half of ephebic sections and may be limited to immediate vicinity of cardinal septum; septa attenuate near periphery where minor septa may be discontinuous. Neanic sections show extensive dilation except for a peripheral attenuate zone which is widest on the counter side. Brephic sections show nearly complete dilation.

Longitudinal sections show a normal well-defined dissepimentarium and tabularium in ephebic position of corallum. The dissepimentarium is composed of many rows of small globose dissepiments occupying about one-half the radius of the section. The tabularium is occupied by incomplete closely spaced arched tabulae. Neanic and brephic areas are partly or wholly occupied by dilation tissue, and dissepiments and tabulae are suppressed.

Remarks.-The description given above is based on 14 incomplete, mature and immature specimens from 3 localities. All the specimens show two of the three growth stages. Variation in the collection is shown by the illustrations; the sample is too small for more detailed analysis.

$P$. quebecensis differs from most previously described species of Phaulactis by (1) the tendency for septal attenuation to start and proceed more rapidly on the counter side of the corallum, and (2) the size and shape of the dissepiments and tabulae and the comparatively well defined separation of the tabularium and dissepimentarium. P. quebecensis is closest to $P$. cyathophylloides Ryder, the type species and Desmophyllum (=Phaulactis) clarki Wedekind. P. cyathophylloides however, has long minor septa, and $P$. clarki has more uniform and persistent dilation in the ephebic stage.

$P$. sp. A Stumm, 1962 (chapter A of this paper) appears to differ from $P$. quebecensis by its long minor septa, but is similar in all other respects; the Maine and Quebec material are probably conspecific.

Occurrence: Mont Wissick formation, locs. F52, 41A, 675.

Material: Holotype, USNM 139220; illustrated paratypes, USNM 139221-139225; unillustrated paratypes, USNM 139226, 139227 and Quebec Bureau of Mines.

\section{Family TRYPLASMATIDAE}

Genus TRYPLASMA Lonsdale

Tryplasma Lonsdale, 1845 , p. 613; Etheridge, 1907, p. 76-77; Hill, 1936, p. 204-206; 1940, p. 405; Schouppé, 1950, p. 80-84; Wang, 1950, p. 226; Stumm, 1952, p. 842; Schouppé, 1954, p. 382; Hill, 1956, p. 312; Bulvanker, 1958, p. 20-22; Oliver, 1960a, p. 96.

Pholidophyllum Lindström, 1871, p. 125; Bulvanker, 1952, p. 10-11.

Spiniferina Penecke, 1894, p. 592.

Stortophyllum Wedekind, 1927, p. 30-31.

Type species.-By subsequent designation of Etheridge (1907, p. 42), T. aequabile Lonsdale (1845, p. 613-614, 633, pl. A, figs. 7, 7a). Silurian, northern Urals, U.S.S.R.

Diagnosis.-Solitary, dendroid or phaceloid corals with spinose (acanthine) septa and a narrow septal stereozone. Tabulae generally complete. No dissepiments.

Remarks.-See Etheridge (1907), Hill (1936, 1940, 1956), Schouppé (1950), and Bulvanker (1958), for more extensive discussions and synonymies.

Species of Tryplasma have been described from Europe, Asia, Australia, and North America, ranging in age from Llandovery (Hill, 1959, p. 165) to Early. Devonian. Only a few North American species have been described (Stumm, 1952; Oliver, 1960a, b), but species of the genus probably are more common there than this would indicate.

\section{Tryplasma nordica Stumm}

Plate 7, figures 1-7

T. nordica Stumm, 1962 (chapter A of this series).

Occurrence of type material.-Silurian, Lobster Lake formation, Piscataquis County, Maine.

Diagnosis.-Solitary Tryplasma with broadly concave tabulae and very short major and minor septa.

External features.-Elongate cylindrical corals, solitary in habit. Dimensions as follows: diameter of cylindrical part of corallum, 8 to $13 \mathrm{~mm}$; length, as much as $6 \mathrm{~cm}$ or more. Exterior broadly rugose, partly due to sharp bends of growth axis. Finer markings not known. Calice very deep with vertical sides from which septal spines project; bottom flat or gently concave.

Internal features.-Septa acanthine, consisting of short septal spines directed inward and upward; major and minor series can be recognized. Peripherally the septa dilate to form a thin uniform septal stereozone. Average length of spines, $1.5 \mathrm{~mm}$; maximum $2 \mathrm{~mm}$ (one-fourth the diameter). Average thickness of epitheca plus stereozone, 0.3 to $0.5 \mathrm{~mm}$. Septa number 
48 to 60 in transverse sections of 7.0 to $10.5 \mathrm{~mm}$ diameter.

Tabulae complete, U-shaped, axially flat or gently convex. Inclined peripheral parts of tabulae may be pierced by septal spines or may carry spines that do not extend to the epitheca. No septal spines are found on the flat or convex axial areas of tabulae.

Remarks.-The description given above is based on more than 20 individuals from localities 52 and $41 \mathrm{~A}$. Observed variation is principally in the length of septal spines and the shape of the tabulae.

$T$. nordica can be distinguished from most other described species of Tryplasma by its concave tabulae, short, attenuate septa, and thin stereozone and tabulae. It is morphologically closest to Pholidophyllum (=Tryplasma) subhedstromi Bulvanker from the Silurian of Podolia, but this species is smaller $(4$ to $5 \mathrm{~mm}$ in diameter) and colonial in habit.

Occurrence: Mont Wissick formation, loc. F52, 41A, F300, 675 . Material: Illustrated specimens, USNM 139228-139230; unillustrated specimens, USNM 139231 and Quebec Bureau of Mines.

\section{Family COLUMNARIIDAE}

\section{Genus COLUMNARIA Goldfuss}

.Columnaria Goldfuss, 1826, p. 72 (part); McCoy, 1849, p. 121122; Lang and Smith, 1935, p. 426-428; Stumm, 1949, p. 29, Hill, 1956, p. 298; Bulvanker, 1958, p. 114-115.

Type species.-By subsequent designation of McCoy (1849, p. 121), Columnaria sulcata Goldfuss (1826, p. 72, pl. 24, figs. 9a-c). Middle Devonian, Germany.

Diagnosis.-Cerioid or phaceloid rugose corals with long or short, thin septa which are peripherally joined in a narrow stereozone. Tabulae generally complete. A single row of vertically elongate dissepiments may double up or be absent locally.

\section{Columnaria? coralliferum (Hall) \\ Plate 8, figures 1-8}

Diplophyllum coralliferum Hall, 1852 , p. 322 , pl. 72 , figs. 1a-c. Diphyphyllum coralliferum (Hall), Hall, 1859, p. 80; Schuchert, 1903, p. 163

Horizon and locality.-Hall's specimen is from the Cobleskill limestone at Schoharie, N.Y.

External features.-Cylindrical rugose corals of small size, presumably phaceloid. Dimensions of cylindrical portion of corallite: diameter 2.5 to $4.0 \mathrm{~mm}$; maximum observed length, $25 \mathrm{~mm}$. External markings consist of rounded interseptal ridges and broad V-shaped septal grooves which give a scalloped appearance in transverse section; gentle rugae are irregularly spaced. Calice steep sided, depth approximately equals diameter Proximal part of corallites, not known.

Internal features.-Septa radially arranged; major septa extend three-fourths or more the distance to the axis; minor septa $1 / 2$ to $2 / 3$ as long. Transverse sections of 8 individuals show 13 to 17 major septa in diameters of 2.5 to $4.0 \mathrm{~mm}$. Zigzag carinae are strongly to weakly developed in most individuals. All septa thicken peripherally and join within a stereozone 0.4 to 0.5 $\mathrm{mm}$ wide.

Longitudinal sections show a few vertically elongate peripheral dissepiments. These tend to be arranged uniserially but double-up in one specimen and are lacking in large parts of all corallites examined. Tabulae complete, widely spaced, strongly depressed axially, slightly arched peripherally.

Septal microstructure is obscured by recrystallization. In transverse section the septa appear featureless, but grade into lamellar tissue forming the stereozone.

Remarks. - The above description is based on 9 transverse and 5 longitudinal thin sections of 13 corallites. Nine of the corallites are embedded in unidentifiable stromatoporids. None of the corallites are proximally complete, and no indication of increase was found.

Diplophyllum coralliferum Hall was inadequately described and poorly illustrated. The type specimens are not certainly known, but a corallum from the type locality was located in the New York State Museum by Clinton F. Kilfoyle, curator. This specimen may possibly be the holotype, but it is certainly a topotype specimen. The Quebec specimens differ from the New York one only by the possession of thickened dissepiments, a character which is not likely to be of specific importance.

Columnaria? coralliferum differs from typical Columnaria by the possession of zigzag carinae, and the species may belong to an undescribed genus.

Corals superficially similar to Columnaria? coralliferum and of the same approximate age, have been referred to Diphyphyllum multicaule (Hall) by several workers. Reexamination of the types of Hall's species shows it to lack dissepiments, but to be rather similar to $C$. ? coralliferum in other respects. Later references to the species (none based on Hall's material) have indicated the presence of dissepiments in material referred to $D$. multicaule from Niagara age rocks in Michigan (Rominger, 1876), Manitoulin Island (Lambe, 1899, 1901; Williams, 1919), Newfoundland (Shrock and Twenhofel, 1939), and Gaspé, Quebec (Northrup, 1939). Some or all of these may be conspecific with Columnaria? coralliferum, and the species may be widespread in eastern North America.

Occurrence: Mont Wissick formation, loc. 318, F233 (rare), F52(?).

Material: Illustrated specimens, USNM 139232-139235; unillustrated specimens, USNM 139236, 139237 and Quebec Department of Mines. 


\section{Family CYSTIPHYLIIDAE}

\section{Genus HOLMOPHYLIUM Wedekind}

Holmophyllum Wedekind, 1927, p. 30; Hill, 1940, p. 397; Wang, 1947 , p. $183 ; 1950$, p. 227; Bulvanker, 1952 , p. $12-13$; Hill, 1956, p. 312 .

Type species.-By original designation of Wedekind (1927, expl. pl. 4), H. holmi Wedekind (1927, p. 31, pl. 4, figs. 6-8; pl. 29, fig. 16).

Diagnosis.-Solitary rugose corals with discontinuous acanthine septa that pierce several dissepiments in a wide dissepimentarium. Tabulae incomplete and irregularly distributed.

Remarks.--Species of Holmophyllum have previously been described from beds of Wenlock and Ludlow age in Europe, Australia, and China. H. pseudocarinatum Stumm (chapter A of this paper), and the Quebec material are the first reported from North America.

\section{Holmophyllum sp. 1}

Plate 5, figures 6,7 ; plate 7 , figures 8,9

External features.-All available specimens are embedded in matrix, but the sections reveal small solitary cylindrical corals with the following dimensions: diameter 7.5 to $8 \mathrm{~mm}$; length, $20 \mathrm{~mm}$ or more. Epitheca gently rugose, marked by longitudinal interseptal grooves and septal ridges. Calice depth greater than the diameter, walls steep; calice tapers downward to flat bottom which equals the tabularium in diameter.

Internal features.- Septa radially arranged, acanthine, extend $1 / 2$ to $2 / 3$ the distance to the axis. Major and minor septa are present, but the two groups cannot everywhere be differentiated with certainty. Septa number 48 to 58 in diameters of 7.5 to $8 \mathrm{~mm}$.

In longitudinal section the tabularium occupies from $1 / 3$ to $1 / 2$ the diameter; tabulae are irregularly but widely spaced and incomplete. The tabulae form a distally concave pattern, but most individual tabulae are convex.

The dissepimentarium is formed of several rows of steeply inclined normal dissepiments which are pierced by acanthine septa directed upward and toward the axis.

Remarks. - The description given above is based on four specimens from locality F52.

Holmophyllum sp. 1 is close to, and possibly conspecific with, H. pseudocarinatum Stumm (chapter A of this paper), but the Quebec specimens are so much smaller than the Maine ones that a larger collection will be needed to determine this.

Material: Illustrated specimens, USNM 139238, 139458, 139459; other specimen, USNM 139239.

\section{Family ARACHNOPHYLLIDAE}

\section{Genus ENTELOPHYLIUM Wedekind}

Entelophyllum Wedekind, 1927, p. 22; Hill, 1940, p. 411-412; Hil and Jones, 1940, p. 188; Wang, 1950, p. 224; Schouppé, 1951, p. 243-256; Sytova, 1952, p. 137-138; Schouppé, 1954, p. 400-401; Duncan, 1956, expl. pl. 23; Hill, 1956, p. 275. Xylodes Lang and Smith, 1927, p. 461-462; Smith and Tremberth, 1929, p. 362-363; Smith, 1933, p. 513; Soshkina, 1937, p. 34 ; Prantl, 1940 , p. 1-4; Bulvanker, 1952 , p. 31 .

Type species.-Madreporites articulatus Wahlenberg, Upper Silurian, Gotland, Sweden, by subsequent designation of Lang, Smith, and Thomas (1940, p. 57).

Diagnosis.-Solitary or phaceloid rugose corals with radially arranged long, thin septa. Dissepimentarium composed of steeply inclined normal dissepiments. Tabularium wide; tabulae divided into regular periaxial part and irregular generally depressed axial part.

Remarks.-Species of Entelophyllum have been described from rocks of Wenlock and Ludlow age of Europe, Asia, Australia, and North America, and may occur in the lowest Devonian also (Ruhkin, 1938; Weissermel, 1943; Schouppé, 1954).

Entelophyllum rugosum Smith, 1933, was described from the Louisville limestone of Niagara age, in Kentucky. According to Stumm (written communication, 1960) two other species from the same formation can also be assigned to Entelophyllum. In addition to these three species, $E$. parvum and $E$. sp. A were described from Maine in chapter $\mathrm{A}$ of this paper.

\section{Entelophyllum sp. 1}

Plate 6, figures 11,12

External features.-Thin sections indicate a cylindrical coral, 7 to $8 \mathrm{~mm}$ in diameter with a broad and shallow, but steep-sided calice. The coral is gently rugose and has rather deep septal grooves and rounded interseptal ridges.

Internal features.-Septa radially arranged; slender major septa, number about 26 , extend nearly to the axis; minor septa are one-third as long. The minor septa and the peripheral one-third of the major septa are thickened to a prominent wedge shape.

The dissepimentarium is narrow and consists of 2 or 3 rows of normal steeply inclined dissepiments. The tabularium occupies three-fourths of the diameter; tabulae consist of a flat depressed peripheral part, a strongly arched periaxial part, and an irregularly depressed axial area. No axial structure is present.

Remarks.-The description given above is based on a single specimen from locality 52 . 
Entelophyllum sp. 1 is close to $E$. parvum Stumm (1962, chapter A of this paper) and may be conspecific. However, $E$. sp. 1 is nearly twice as large and cannot be adequately defined on the basis of available material.

Material: Illustrated specimen, USNM 139240, Mont Wissick formation, Squateck area (loc. F52), Quebec.

\section{REFERENCES CITED}

Bailey, L. W., and McInnes, W., 1888, Report on explorations and surveys in portions of northern New Brunswick and adjacent areas in Quebec and in Maine: Canada Geol. Survey Ann. Rept. 3, 52 p.

Boucot, A. J., 1961, Stratigraphy of the Moose River synclinorium, Maine: U.S. Geol. Survey Bull. 1111-E, p. 153-188.

Bulvanker, E. Z., 1952 [Rugose corals from the Silurian of Podolia]: U.S.S.R., Ministry of Geology and Mineral Deposits (VSEGEI), Leningrad, $46 \mathrm{p.,} 6 \mathrm{pl}$.

- 1958 [Devonian tetracorals from the periphery of the Kuznetz Basin]: Ministry of Geology and Mineral Deposits (VSEGEI), Leningrad, $212 \mathrm{p.}, 93 \mathrm{pl}$.

Duncan, Helen, 1956, Ordovician and Silurian coral faunas of western United States: U.S. Geol. Survey Bull. 1021-F, p. 209-236, pls. 21-27.

Etheridge, Robert, Jr., 1907, A monograph of the Silurian and Devonian corals of New South Wales, part 2, The genus Tryplasma: New South Wales Geol. Survey Palaeontology, no. 13, p. $41-102$, pls. $10-28$.

Goldfuss, G. A., 1826, Petrefacta Germaniae, v. 1, pt. 1: Düsseldorf, Germany, p. 1-76, pls. 1-25.

Hall, James, 1852, Descriptions of the organic remains of the lower middle division of the New York system: Paleontology of New York, v. 2, 362 p., $84 \mathrm{pl}$.

- 1856, Catalog of the species of fossils of New York: New York State Cabinet Ann. Rept. 12, p. 63-96.

Hill, Dorothy, 1936, The British Silurian rugose corals with acanthine septa: Royal Soc. London Philos. Trans., Ser. B, no. 534 , v. 226 , p. $189-217$, pls. 29,30 .

1940, The Silurian Rugosa of the Yass-Bowning District, N.S.W.: Linnean Soc. New South Wales Proc., v. 65, p. 388-420, pls. 11-13.

- 1956, Rugosa, in Moore, R. C., ed., Treatise on invertebrate paleontology, pt. F, Coelenterata: Geol. Soc. America and Kansas Univ. Press, p. 233-324.

- 1959, Distribution and sequence of Silurian coral faunas: Royal Society New South Wales Jour. and Proc., v. 92, p. 151-173.

Hill, Dorothy, and Jones, O. A., 1940, The corals of the Garra beds, Molong district, New South Wales: Royal Soc. New South Wales Jour. and Proc., v. 74, p. 175-208, pls. 2-8.

Jones, O. A., 1936, On the Silurian corals-Cyathophyllum shearsby $i$ and Heliophyllum yassense: Queensland Mus. Mem. 11, p. $53-58$, pls. $5-7$.

Kindle, E. M., 1914, Columnar structure in limestone: Canada Geol. Survey, Mus. Bull. 2, p. 35-39.

Lambe, L. M., 1899, On some species of Canadian Paleozoic corals: Ottawa Naturalist, v. 12, p. 217-226, 237-258. - 1901, A revision of the genera and species of Canadian Paleozoic corals, pt. 2: Canada, Geol. Survey, Contr. Canadian Palaeontology, v. 4, pt. 2, p. 97-197, pls. 6-18.

Lang, W. D., and Smith, Stanley, 1927, A critical revision of the rugose corals described by William Lonsdale in Murchison, R. I., Silurian System: Geol. Soc. London Quart. Jour., v. 83, p. $448-491$, pls. $34-37$.
Lang, W. D., and Smith, Stanley, 1935, On the genotype of Columnaria Goldfuss: Annals and Mag. Nat. History, ser. 10 , v. 16 , p. $426-433$, pl. 12 .

Lang, W. D., Smith, Stanley, and Thomas, H. D., 1940, Index of Palaeozoic coral genera. London, British Mus. (Nat. History), $231 \mathrm{p}$.

Lespérance, P. J., 1959, Preliminary report on Squateck area (west half), Témiscouata, Rivière-du-Loup, and Rimouski electoral districts: Quebec Dept. Mines, Geol. Surveys Br., Prelim. Rept. 385, 10 p., map.

Lindström, Gustav, 1871, Om operkularbildningen hos några nutida och siluriska koraller; Köngl. Vetensk.-Akad. Öfvers., Förhandl., v. 27, p. 921-926; Geol. Mag., ser. 1, v. 8, p. 122-126 [in English].

Lonsdale, William, 1845, Description of some Paleozoic corals of Russia, pt. 1 of Murchison, R. I., de Verneuil, E., and von Keyserling, A., The geology of Russia in Europe and the Ural Mountains: London, John Murray, p. 591-634.

McCoy, F., 1849, On some new genera and species of Canadian Paleozoic corals and foraminifera: Annals and Mag. Nat. History, ser. 2, v. 3, p. 1-20, 119-136.

McGerrigle, H. W., 1934, Témiscouata occidental, et region limitrophe de Kamouraska et Riviére-du-Loup: Quebec Bur. Mines Ann. Rept. 1933, pt. D, p. 105-146.

Northrup, S. A., 1939, Paleontology and stratigraphy of the Silurian rocks of the Port Daniel-Black Cape region, Gaspé: Geol. Soc. America Spec. Paper 21, 302 p., 28 pls.

Oliver, W. A., Jr., 1960a, Rugose corals from reef limestones in the Lower Devonian of New York: Jour. Paleontology, v. 34 , p. $59-100$, pls. $13-19$.

- 1960b, Devonian rugose corals from northern Maine: U.S. Geol. Survey, Bull. 1111-A, p. 1-23, pls. 1-5.

Penecke, K. A., 1894, Das Grazer Devon: K.-k. Geol. Reichsanst. Jahrb., Jahrg. 1893, v. 43, p. 567-616, pls. 7-12.

Prantl, Ferdinand, 1940, Korallengattung Xylodes Lang and Smith im böhmischen Silur: Czechoslovakia, Akad. Wiss. Mitt., Prague, 21 p., 3 pls.

Rominger, Carl, 1876, Palaeontology, fossil corals: Michigan Geol. Survey, v. 3, pt. 2, 161 p., 55 pls.

Rukhin, L. B., 1938 [The lower Paleozoic corals and stromatoporoids of the upper part of the Kolyma river]: U.S.S.R., The State Trust Dalstroy, Contr. Knowledge of KolymaIndighirka Land, ser. 2, pt. 10, 119 p., 28 pls.

Ryder, T. A., 1926, Pycnactus, Mesactis, Phaulactis, gen. nov., and Dinophyllum Lind.: Annals and Mag. Nat. History, ser. 9 , v. 18 , p. $385-401$, pls. 9-12.

Schouppé, Alexander, 1950, Kritische Betrachtungen zu den Rugosen-Genera des Formenkrieses Tryplasma Lonsd. Polyorophe Lindstr.: Österreich Akad. Wiss., math.-nat. Kl., Sitzungsber., div. 1, v. 159, p. 75-85.

- 1951, Kritische Betrachtungen und Revision des Genusbegriffes Entelophyllum Wdk. nebst einigen Bemärkungen zu Wedekinds "Kyphophyllidae und Kodonophyllidae": Österreich Akad. Wiss., math.-nat. Kl., Sitzungsber., div. 1, v. 160 , p. $243-256,2$ pls.

1954, Korallen und Stromatoporen aus dem ef der kärnischen Alpen: Neues Jahrb. Geol. u. Paläont., Abh., v. 99, p. $379-450$, pls. $25-27$.

Schuchert, Charles, 1903, On the Manlius formation of New York: Am. Geologist, v. 31, p. 160-178.

Shrock, R. R., and Twenhofel, W. H., 1939, Silurian fossils from northern Newfoundland: Jour. Paleontology, v. 13, p. 241266, pls. 27-29. 
Smith, Stanley, 1930, Some Valentian corals from Shropshire and Montgomeryshire, with a note on a new stromatoporoid: Geol. Soc. London Quart. Jour., v. 86, p. 291-330, pls. 26-29. 1933, On Xylodes rugosus sp. nov., a Niagaran coral: Am. Jour. Sci., 5th ser., v. 26, p. 512-522, 1 pl.

Smith, Stanley, and Tremberth, Reginald, 1929, On the Silurian corals Madreporites articulatus Wahlenberg, and Madrepora truncata L.: Annals and Mag. Nat. History, ser. 10, v. 3, p. $361-376$, pls. 7,8 .

Soshkina, E. D., 1937 [Corals of the Upper Silurian and Lower Devonian of the eastern and western slopes of the Urals]: U.S.S.R., Acad. Sci., Inst. Paleozoology Trans., v. 6, pt. 4, 112 p., 21 pls.

Stumm, E. C., 1949, Revision of the families and genera of the Devonian tetracorals: Geol. Soc. America Mem. 40, 92 p., 25 pls.

1952, Species of the Silurian rugose coral genus Tryplasma from North America: Jour. Paleontology, v. 26, p. 841-843, pl. 125 .
Stumm, E. C., 1962, Silurian corals from the Moose River synclinorium, Maine: U.S. Geological Survey Prof. Paper 430-A, p. 1-9, pls. 1-4.

Sytova, V. A., 1952 [Upper Silurian corals of the family Kyphophyllidae from the Urals]: U.S.S.R., Acad. Sci., Paleont. Inst. Treatise, v. 40, p. 127-158, 6 pls.

Wang, H. C., 1947, New material of Silurian rugose corals from Yunnan: Geol. Soc. China Bull. 27, p. 171-188, pls. 1, 2.

- 1950, A revision of the Zoantharia Rugosa in the light of their minute skeletal structures: Royal Soc. London Philos. Trans., Ser. B, no. 611 , v. 234, p. 175-246, pls. 1-9.

Wedekind, Rudolf, 1927, Die Zoantharia Rugosa von Gotland: Sveriges Geol. Undersök, Ser. Ca, no. 19, 95 p., 30 pls.

Weissermel, Waldemar, 1943, Korallen von der Silur-DevonGrenze aus West-und Mittledeutschland: Deutschen Geol. Gesell., Zeitschr., v. 95, pt. 1-2, p. 13-32, pls. 2, 3.

Williams, M. Y., 1919, The Silurian geology and fauna of Ontario Peninsula and Manitoulin and adjacent islands: Canada Geol. Survey Mem. 111, 195 p., 34 pls. 
: 


\section{INDEX}

[Italic numbers indicate descriptions]

\begin{tabular}{|c|c|c|}
\hline & ge & Page \\
\hline equabile, Tryplasma... & 13 & holmi, Holmophyllum... \\
\hline Alveolites $\mathrm{sp} . . . . . . . . . .$. & 11 & Holmophyllum........... \\
\hline Anticosti, Quebec........ & 12 & 15 \\
\hline articulatus, Madreporites. & 15 & pseudocarinatum...... \\
\hline Asia.... 13 & & sp. 1 . \\
\hline Auloporoid coral & 11 & \\
\hline Australia & & 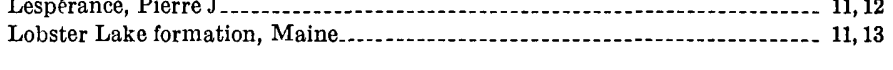 \\
\hline 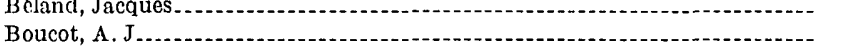 & $\begin{array}{l}11 \\
12\end{array}$ & Madreporites articulatus........................ \\
\hline Brachiopods, Mont Wissick formation. & 12 & $\begin{array}{l}\text { Maine } \\
\text { Mont Wissick formation, Quebec... }\end{array}$ \\
\hline (n) & 11 & nclinorium area, Maine.-.-.- \\
\hline Chaleurs Bay, Quebec. & 12 & multicaule, Diphyphyllum \\
\hline China....- 12 & & \\
\hline Cladopora sp. & 11 & New York, eastern................... \\
\hline$\eta(=$ Phaulactis $)$ & $\begin{array}{l}13 \\
13\end{array}$ & 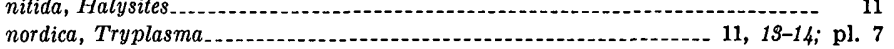 \\
\hline Cobleskill limestone, New York & & North America..................... \\
\hline $\begin{array}{l}\text { Columnaria } \\
\quad \quad=\text { coralliferum. }\end{array}$ & & occidentalis, Favosites.-.-... \\
\hline 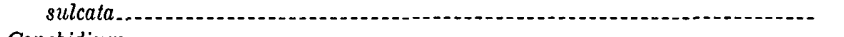 & 14 & Paleofavosites......................... \\
\hline Conchidium & 12 & sp \\
\hline coralliferum, Columnaria & & parvum, Entelophyllum............. \\
\hline lllum & 14 & petaliformis, Plasmopora............. \\
\hline loides, Phaulactis & 14 & 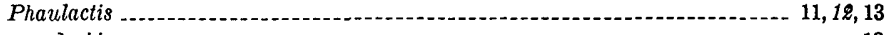 \\
\hline cyathophylloides, Phaulactis. & 13 & 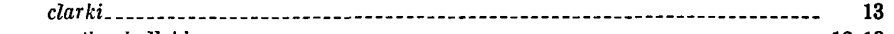 \\
\hline a mplitubulata........ & 12 & quathophylloides. \\
\hline$=$ Phaulactis) clarki & 13 & $-1-1-10$ \\
\hline (n) & 14 & Pinckney, William C., Jr........................ \\
\hline Diplophyllum coralliferum...- & 14. & yllum subhedstromi \\
\hline & & a petaliformis................... \\
\hline 1 & & $\begin{array}{l}\text { Podolia, U.S.S.R. } \\
\text { praecedens, Favosites helderbergiae }\end{array}$ \\
\hline 1 & 16 & pseudocarinatum, Holmophyllum \\
\hline 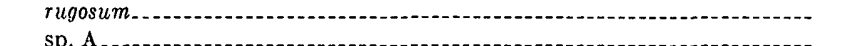 & 15 & $\ldots 11,12,13,14,16$ \\
\hline (1) 15-16; $\mathrm{p}$ & & quebecensis, Phaulactis_........ \\
\hline 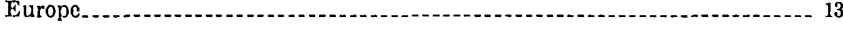 & & \\
\hline Favosi & 11 & 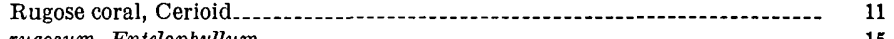 \\
\hline praecedens...-.-. & 11 & yllum..... \\
\hline 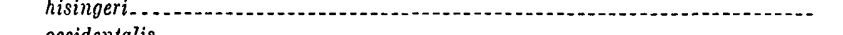 & 11 & Squateck West area, Quebec.... \\
\hline lis......... & 11 & 14 \\
\hline 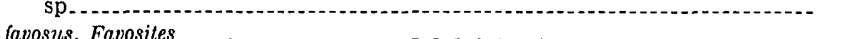 & 11 & (n) \\
\hline vosus, Favosites & 11 & (n) \\
\hline - n- & 1 & \\
\hline d, Sweden....... & & Trypl \\
\hline Halysite & 12 & $11,19-14:$ \\
\hline & & 14 \\
\hline acedens, Favosites. & & \\
\hline & & U.S.S.R. \\
\hline & & \\
\hline
\end{tabular}





\section{A New Kodonophyllum and}

Associated Rugose Corals

from the Lake Matapedia

Area, Quebec

By WILLIAM A. OLIVER, JR.

SILURIAN CORALS FROM MAINE AND QUEBEC

GEOLOGICAL SURVEY PROFESIONAL PAPER 430-C

Description of a new species of a Silurian

rugose coral genus not previously recognized

in North America

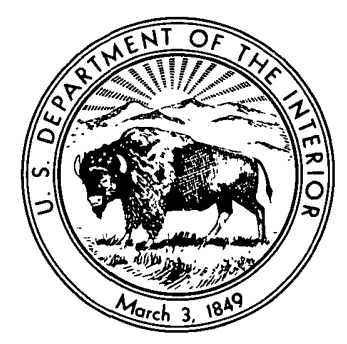




\section{CONTENTS}

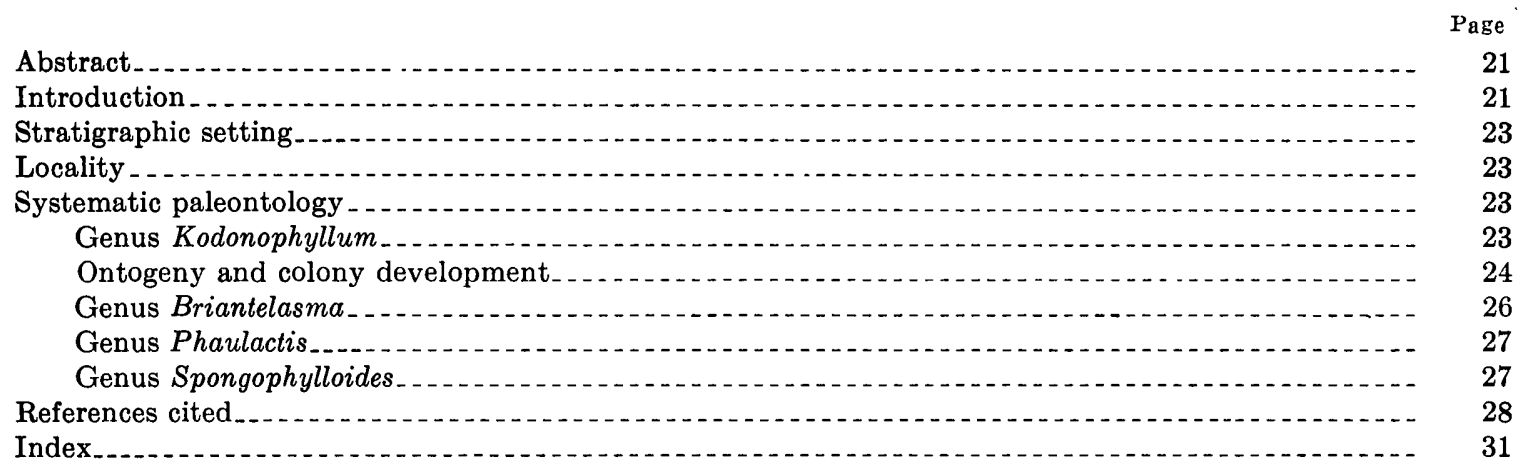

\section{ILLUSTRATIONS}

[Plates follow Index]

Plate 9-13. Kodonophyllum corymbosum n. sp.

14. Spongophylloides, Phaulactis, and Briantelasma spp.

FIGURE 1. Index map showing the general location of the three areas in Maine and Quebec from which Gotland-type coral faunas have been described . .

2. Ontogenetic diameter increase relative to septal number in 67 transverse thin sections of 25 or more corallites of Kodonophyllum corymbosum . . . . . . .

3. Ontogenetic diameter increase relative to septal number in 7 serial sections of corallite 3

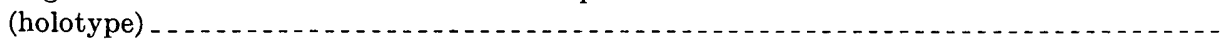

4. Ontogenetic tabularium-diameter increase relative to septal number in 65 transverse thin sections of 25 or more corallites of Kodonophyllum corymbosum

5. Ontogenetic tabularium-ratio decrease relative to septal number in 65 transverse thin sections of 25 or more corallites of Kodonophyllum corymbosum

6. Ontogenetic variation in diameter with tabularium diameter in 65 transverse thin sections of 25 or more corallites of Kodonophyllum corymbosum 



\section{A NEW KODONOPHYLLUM AND ASSOCIATED RUGOSE CORALS FROM THE LAKE MATAPEDIA AREA, QUEBEG}

By William A. Oliver, Jr.

\section{ABSTRACT}

Elements of the Silurian coral fauna of Gotland, Sweden, are present in the Sayabec formation of the Lake Matapedia area, Quebec. Species of Kodonophyllum, Phaulactis, Spongophylloides, and Briantelasma are represented, but only the first of these has been collected in sufficient numbers to warrant formal description; the others are only briefly considered and illustrated.

The Kodonophyllum is the first species of the genus described from an area outside Europe. Individual ontogeny and colony development are illustrated and discussed.

\section{INTRODUCTION}

The three studies represented by chapters A, B, and $\mathrm{C}$ of this paper originated independently and were in an advanced stage of development before their relationship became obvious. The corals described by Stumm (1962) in chapter A are from a northeast-trending area, about 60 miles long, in the Moose River synclinorium (fig. 1) of Franklin, Somerset, and Piscataquis Counties, Maine. The Lake Témiscouata area covered in chapter B (Oliver, 1962) is about 170 miles N. $20^{\circ} \mathrm{E}$. of the central part of the Moose River synclinorium (fig. 1). The Lake Metapedia area (this report) is 75 miles northeast of Lake Témiscouata and 230 miles N. $30^{\circ}$ E. of the Moose River synclinorium.

The following table summarizes the distribution of rugose corals described in chapters $A, B$, and $C$ ( $X$ indicates occurrence; sp. indicates that the same species is present):

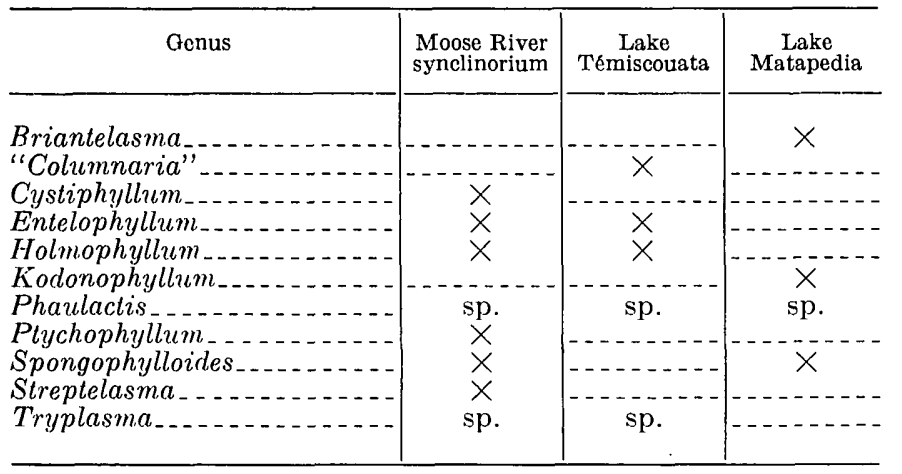

All three faunas are of Wenlock or Ludlow age (Middle and Late Silurian) for Entelophyllum, Holmophyllum, and Spongophylloides are not known from older rocks, and Entelophyllum, Holmophyllum, Kodonophyllum, and Phaulactis are not known from younger ones. Only Phaulactis quebecensis is known from all three areas, but the faunas are small and the lack of taxa in common is not necessarily indicative of noncorrelation.

Four of the five rugose genera from the Lake Témiscouata area are also described from Maine. At least two species and possibly four occur in both areas. (See remarks accompanying the descriptions in chapter B.) Comparison of the tabulate coral faunas emphasizes the similarities. Eight genera are described from Maine; nine are listed from Lake Témiscouata; five genera and at least three species occur in both areas. These comparisons suggest that the Hardwood Mountain and Lobster Lake formations in Maine (chapter A) are of the same approximate age as the Mont Wissick formation in Quebec (chapter B).

The brachiopods from all three formations in the Moose River synclinorium and Lake Témiscouata areas have been studied by A. J. Boucot. He considers them to be early Ludlow age (oral communication, 1961).

The Sayabec formation rugose coral fauna (this report) is small (four species) and the tabulates are not available for study. Phaulactis quebecensis probably is present (as in the other areas), but the Spongophylloides from the Sayabec is certainly not conspecific with the one from Maine, and neither Kodonophyllum nor Briantelasma is known from either of the other two areas. Correlation of the Sayabec formation with the Mont Wissick, Hardwood Mountain, and Lobster Lake formations is not supported by the coral data. Boucot (oral communication, 1961) considers the Sayabec brachiopods to be of Wenlock age.

Four of the 11 coral genera listed above have not 
22

SILURIAN CORALS FROM MAINE AND QUEBEC

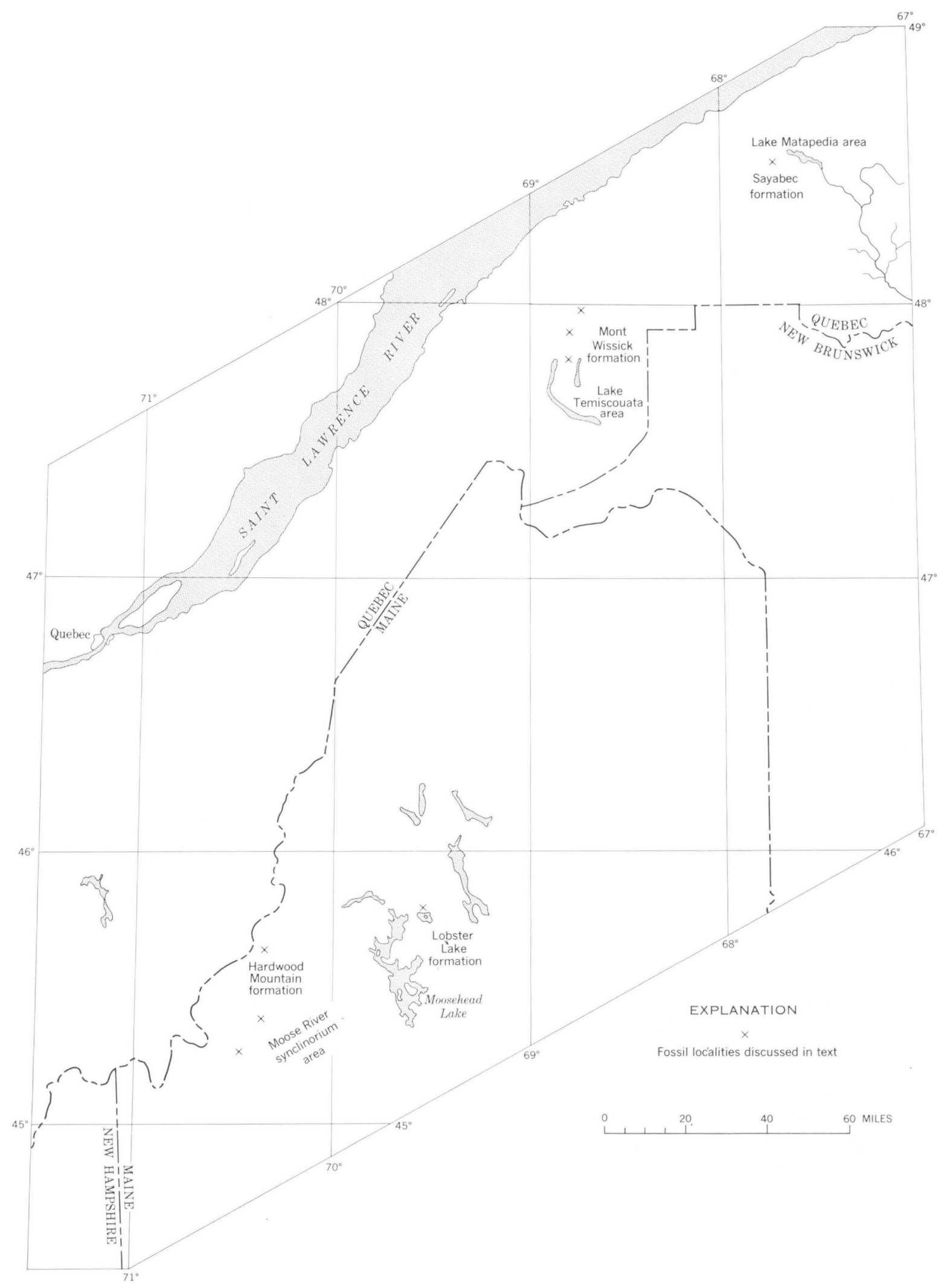

FIGURE 1. -Index map showing the general location of the three areas in Maine and Quebec from which Gotland-type coral faunas have been described. 
previously been described from North America: Holmophyllum, Kodonophyllum, Phaulactis, and Spongophylloides. The taxa Briantelasma, "Columnaria" coralliferum, and Ptychophyllum are North American elements. The remaining four genera are more or less cosmopolitan. As a whole, the fauna is more similar to the coral fauna of Gotland, Sweden, than to any described from America.

The corals from the Lake Matapedia area were collected by Jean Lajoie in the course of fieldwork for the Quebec Department of Mines. I am indebted to Lajoie and to Dr. Jacques Béland, of the Department of Mines, for permission to describe the corals. Thin sections were prepared by William C. Pinckney, Jr., of the U.S. Geological Survey; photographs are by the author.

\section{STRATIGRAPHIC SETTING}

Béland (1960) has outlined the stratigraphy and structure of the Matapedia Valley area and redescribed the Sayabec formation that was originally named by Crickmay (1932). Béland (1960, p. 6) described the formation as follows: "It is made up mostly of a pure, fossiliferous, light to dark-gray limestone in which are thin beds. [of] argillaceous and silty rocks $* * *$. Part of the limestone is made up of large and small angular fragments of corals and algae set in a matrix of fine-grained limestone." The Sayabec grades downward into the Val Brillant quartz sandstone and upward into the St. Leon siltstone. In the collection area, the Sayabec formation is about 1,200 feet thick (Lajoie, Jean, written communication, 1960).

Crickmay (1932) correlated the Sayabec formation with the La Vieille formation in the Chaleurs Bay area farther east. The Canada Geological Survey (1957, p. 156) made the same correlation, but indicated the La Vieille to be of lower Lockport age (p. 154). Boucot (oral communication, 1961) assigned a Wenlock (pre-Lockport) age on the basis of his study of the brachiopods.

The Lajoie collection includes the following rugose corals:

Kodonophyllum corymbosum n. sp.

Briantelasma sp.

Phaulactis sp.

Spongophylloides sp.

Kodonophyllum, Phaulactis and Spongophylloides occur widely in the Silurian of Europe. Spongophylloides is not known to occur in rocks of pre-Wenlock age, and neither Kodonophyllum nor Phaulactis are known in the Lower Devonian. All three genera are common in strata of both Wenlock and Ludlow age and together indicate this age range for the part of the Sayabec formation from which they have been collected. Brian- telasma has been known previously only from beds of Early Devonian age in New York and Maine (Oliver, $1960 \mathrm{a}, \mathrm{b})$. Its occurrence with the other three genera indicates a downward extension of its range into the Silurian.

\section{LOCALITY}

All the described and illustrated corals are from the Sayabec formation, 16,000 feet N. $30^{\circ}$ E. of La Redemption village, on lots 18 and 19, of Range II, Awantjish Township, Matapedia County, Quebec. The locality is marked as a "Fossil locality" on Beland's map (1960). Collections were made along three parallel, cross-strike traverses, one-seventh of a mile apart, designated from southwest to northeast as $A, B$, and $C$ by Lajoie.

\section{SYSTEMATIC PALEONTOLOGY}

\section{Family STREPTELASMATIDAE}

Subfamily KODONOPHYLLINAE

\section{Genus KODONOPHYLLUM Wedekind}

Kodonophyllum Wedekind, 1927, p. 35-36; Smith and Tremberth, 1929, p. 367-368; Soshkina, 1937, p. 52-53; Hill, 1956, p. 271.

Patrophontes Lang and Smith, 1927, p. 456-457;

Codonophyllum Lang, Smith, and Thomas, 1940, p. 39; Wang, 1948, p. $104 ; 1950$, p. 214.

Type Species.-By original designation, Streptelasma milne-edwardsi Dybowski (1873, p. 410-415), Silurian, Island of Karlso, Sweden, = Madrepora truncata Linnaeus (1758, p. 795), Silurian, Island of Gotland, Sweden (Lang, Smith, and Thomas, 1940, p. 39).

Diagnosis.-Solitary or weakly fasciculate rugose corals with peripheral budding and a very wide septal stereozone to which minor septa are limited. Major septa extend nearly to the axis, but are attenuate in tabularium. Tabulae are incomplete and arched; no dissepiments.

Remarks.-Species of Kodonophyllum have been described from rocks of Silurian age in Europe, from England eastward through Gotland to the Urals, U.S.S.R. A single species was described from Upper Ordovocian rocks in Estonia by Kaljo (1957, p. 159). The Quebec species is the first described from an area outside Europe.

\section{Kodonophyllum corymbosum n. sp.}

Plates 9-13

Diagnosis.-Weakly phaceloid Kodonophyllum with peripheral increase; tabulae incomplete, axially flat and periaxially arched.

External features.-Trochoid to ceratoid small rugose corals with maximum diameter, $18 \mathrm{~mm}$, and length as much as $60 \mathrm{~mm}$. Exterior with low rounded interseptal ridges and coarse encircling rugae. The calice, 
known only in sections, is moderately deep and broadly $V$-shaped. Peripheral buds are developed in the outer part of the calice of many individuals. Some corallites are attached to others by broad lateral extensions of the peripheral stereozone.

Internal features.-Septa radially arranged. Major septa number 22 to 29 in 24 transverse sections of 10 to $18 \mathrm{~mm}$ diameter (fig. 2). Minor septa are approximately half as long as the major ones. The minor septa and the outer half of each major septum are dilated and in lateral contact. The septal stereozone thus formed is very regular in outline and completely fills the outer 0.5 to 0.6 of the radius of the coral. Major septa attenuate sharply at the inner margin of the stereozone and extend nearly to the axis where they expand slightly (rhopaloid) and may bend and join in an irregular fashion, although no axial structure is formed.

In longitudinal section the solid stereozone fills the outer part of the corallite. The tabularium is composed of axially flat and periaxially arched incomplete tabulae which are thin, or thickened with stereome.

Microstructure.-The microstructure of the described specimens is very similar to the structure shown in illustrations of $K$. truncatum by Lang and Smith (1927, p. 456 , text figs. 8,9$)$ and by Smith and Tremberth (1929, pl. 8, figs. 6, 7). In longitudinal section the septa show prominent but irregular structural units inclined upward from the periphery to the inner margin of the stereozone. These probably reflect the primary orientation of the trabeculae, but finer details are obscured by secondary recrystallization. In transverse section the structural units appear as end or oblique views, each septum being one unit wide. Where locally preserved, a fibrous pinnate structure suggests the monacanthine trabeculae of Hill (1936, p. 197, fig. 14). It is as though monocanths had been recrystallized as units, preserving the original orientation but destroying most of the pinnate structure of the individual trabeculae.

Remarks.-The description given above is based on a group of 25 or more individuals from a single block of limestone, 6 by 10 by $12 \mathrm{~cm}$. Although some of the individuals bud off others, there is no proof that the whole is a single colony. However, variation in such a sample is likely to be less than in a more representative collection.

$K$. corymbosum differs from other species of Kodonophyllum by its wide stereozone and in the shape of its tabulae. It is very close to the type species $K$. truncatum, but in that species the tabulae are strongly arched, incomplete, and lack the axial flat part which is observed in $K$. corymbosum.
Occurrence: Sayabec formation about 700 feet above the base on traverse $C$ (holotype and associated individuals); traverse $B$, about 700 feet above the base (a single small-sized corallite, pl. 13, figs. 7,8$)$.

Material: Holotype and associated illustrated paratypes, USNM 139460; illustrated paratype from traverse $B$, USNM 139461.

\section{Ontogeny and colony development}

Hill (1935, p. 491-492; 1956, fig. 173, p. 244) reviewed, summarized, and illustrated the terminology of corallum development in rugose corals. Specialized terms used in the following discussion are from Hill, but they may be briefly defined as follows. An offset is the skeleton of a bud or daughter polyp, attached to a protocorallite, the skeleton of the parent polyp. Skeletal tissue formed by the parent as part of the protocorallite but utilized and built-on by the daughter is atavotissue; skeletal tissue formed by the daughter alone is neotissue. An offset is composed of both neotissue and atavotissue in its early stages, but the two terms are not meaningful after the offset assumes its adult characteristics.

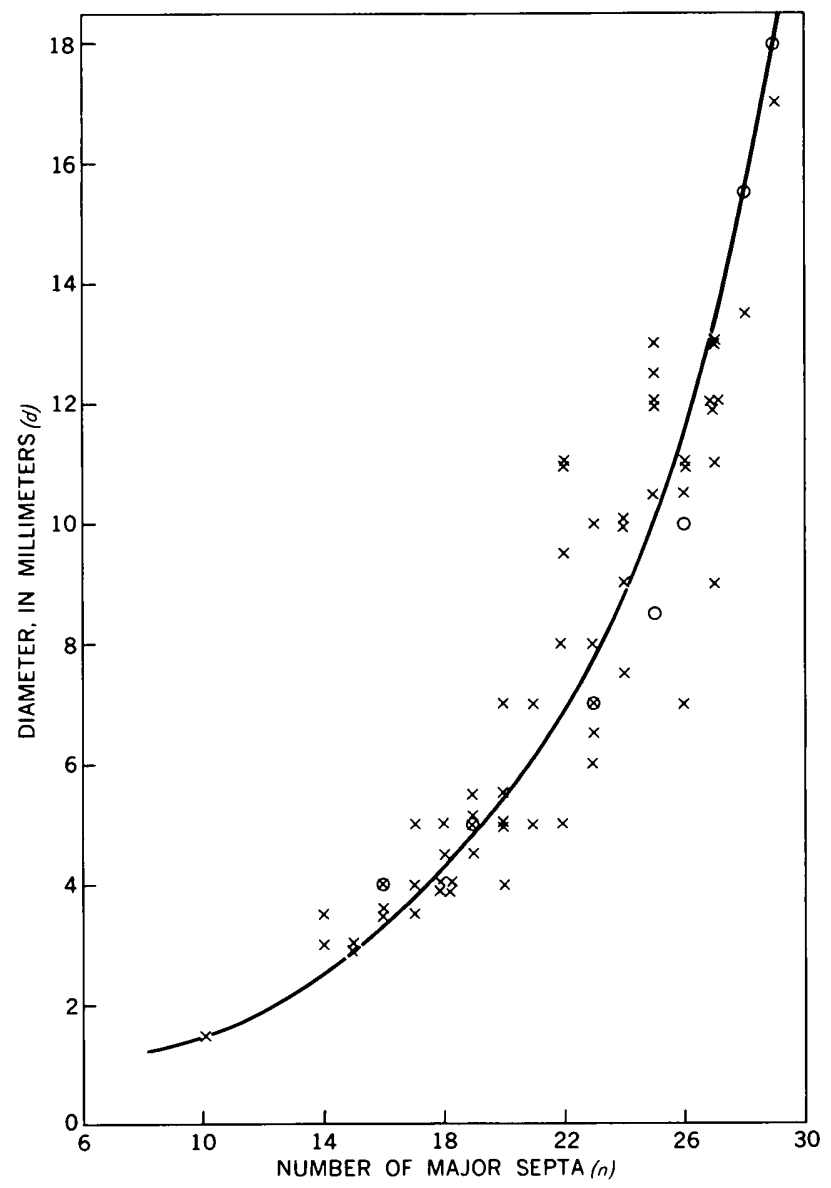

Figure 2.-Ontogenetic diameter increase relative to septal number in $\mathbf{6 7}$ transverse thin sections of 25 or more corallites of Kodonophyllum corymbosum. Circles represent data from 7 serial sections of corallite 3 (holotype). Curve fitted visually. 


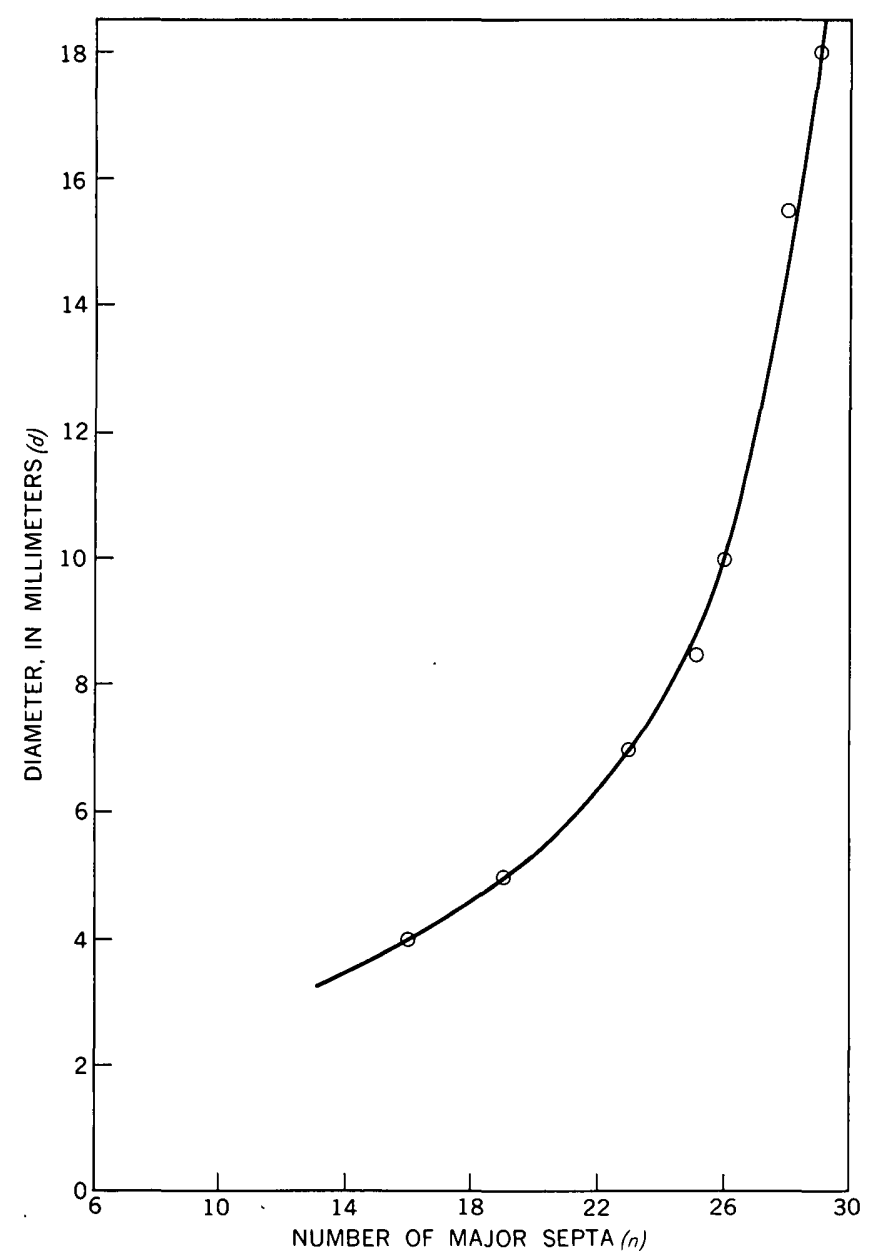

Figure 3.-Ontogenetic diameter increase relative to septal number in 7 serial sections of corallite 3 (bolotype). Curve fitted visually.

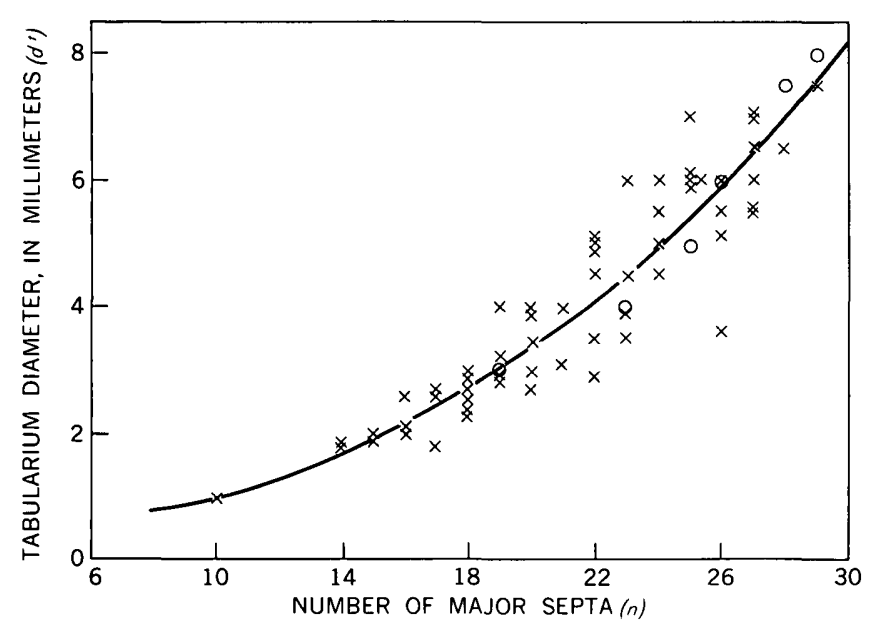

Figure 4.-Ontogenetic tabularium-diameter increase relative to septal number in 65 transverse thin sections of 25 or more corallites of Kodonophyllum corymbosum. Circles represent data from 6 serial sections of corallite 3 (holotype). Curve fitted visually.

Corallum development has been described in only a few species of rugose corals, mostly with different growth forms from that of Kodonophyllum corymbosum.

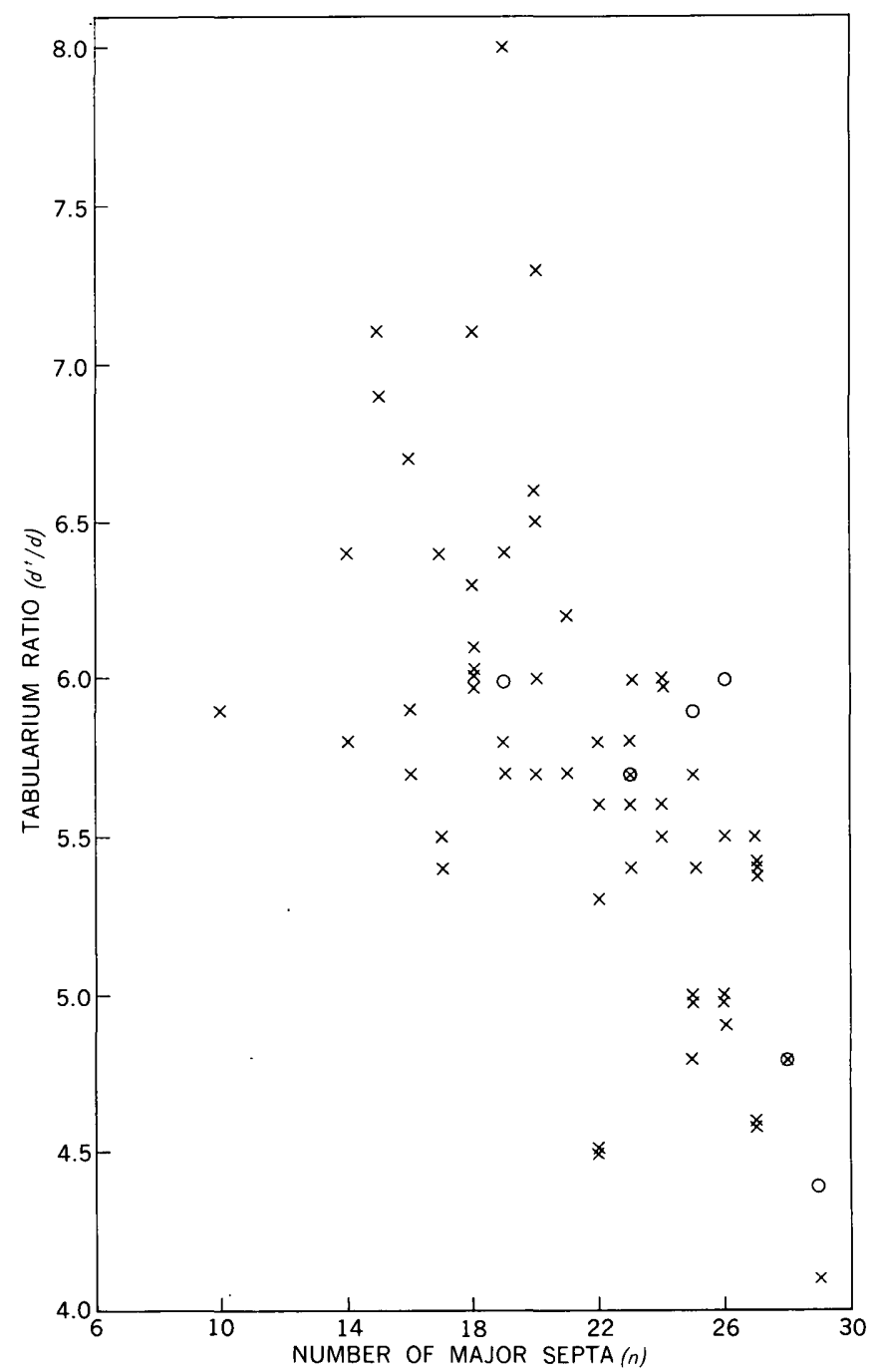

FIGURE 5.-Ontogenetic tabularium-ratio decrease relative to septal number in 65 transverse thin sections of 25 or more corallites of Kodonophyllum corymbosum. Circles represent data from 6 serial sections of corallite 3 (holotype).

The form and development of Entelophyllum articulatum (Wahlenberg) is very similar, however (Smith and Tremberth, 1929, p. 370-372). This species differs only in having relatively larger and more numerous offsets so that neotissue forms an almost complete epithecal ring around the axial area of the protocorallite. In contrast, $K$. corymbosum offsets are small and generally well separated from each other.

Eight serial transverse sections through a clump of $K$. corymbosum are illustrated on plates 9 and 10 . Orientation of corallites within the clump is regular enough so that the serial sections show the ontogeny of several individuals as well as the development of offsets in calices. Numbers on the photograph keys designate successive sections of the same individual.

Increase takes place within the calice, generally on the peripheral platform, although the single offset in corallite 6 (pl. 9, fig. 1 ; pl. 10, fig. 6) occupies most of 


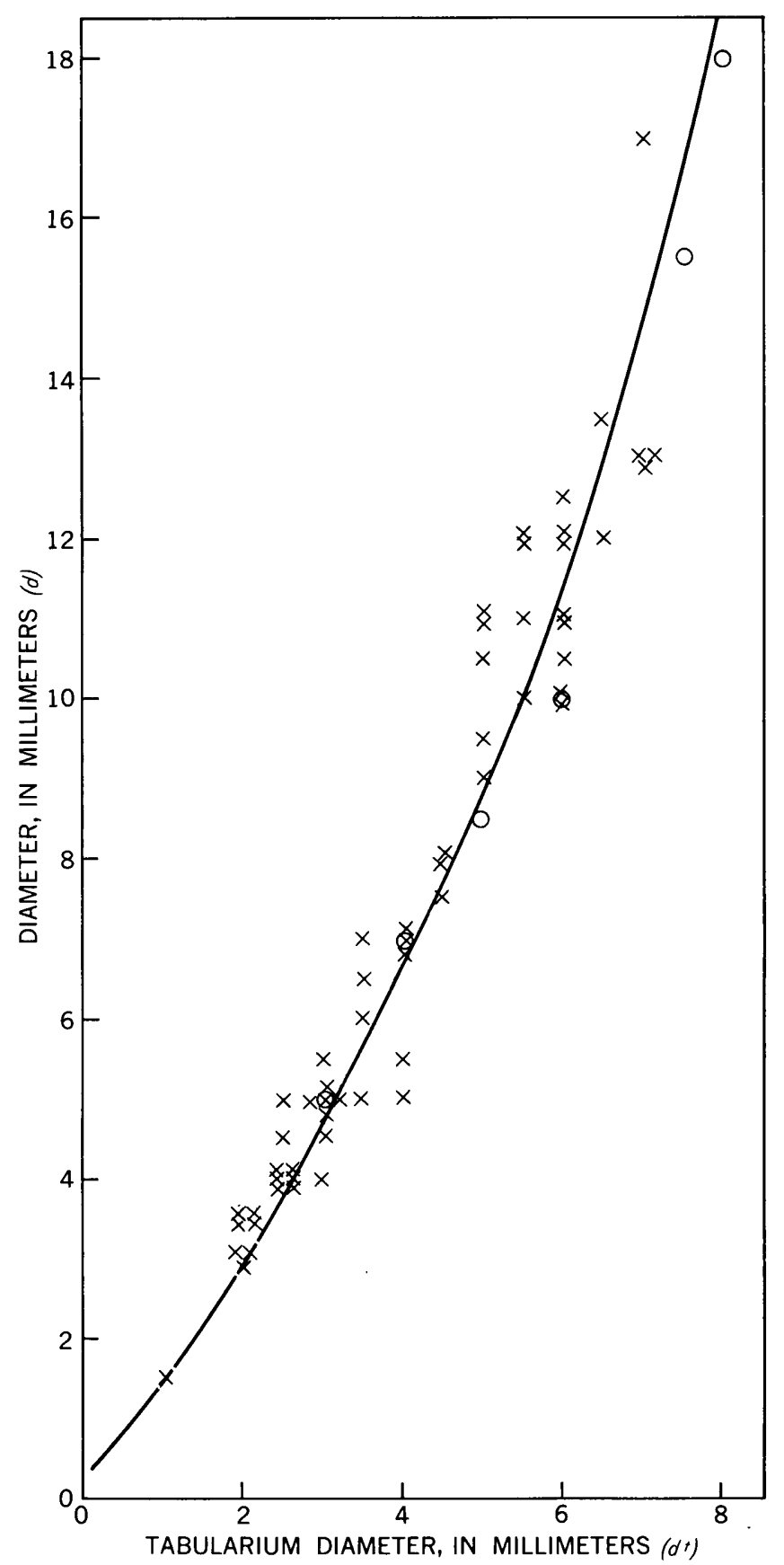

Figure 6.-Ontogenetic variation in diameter with tabularium diameter in 65 transverse thin sections of 25 or more corallites of Kodonophyllum corymbosum. Circles represent data from 6 serial sections of corallite 3 (holotype). Curve fitted visually.

the parental calice and is virtually an example of rejuvenation. In the specimens studied, from 1 to 5 or 6 offsets were formed by a parent corallite in a given reproductive phase. The offsets in the calice of corallite 3 (pl. 11, figs. 8-12) illustrate several stages of their development. These and others shown on plates 12 and 13 are cited in the following discussion.

Initially the offset appears as a bulge on the inner wall of the calice (stage 1). The bulge is formed by neotissue which becomes one side of the offset (pl. 12, figs. 1, 4). The septa of the parent on which the bulge appears are little affected but form part of the new calice (atavotissue). A second stage is begun by the development of very small septa on the neoside of the offset (pl. 11, fig. 9; pl. 12, fig. 2 ; pl. 13, figs. 4, 5). To this point the textural contrast between neotissue and atavotissue in the offset is distinct (pl. 13, fig. 5). Gradually the bulge expands (pl. 11, fig. 10; pl. 12, fig. 3; pl. 13, figs. 3, 6) and septa become uniform in size within the offset (stage 3), although those on the atavoside represent new growth on parental septa (pl. 11, fig. 11 ; pl. 12, figs. 5, 6). After the offset becomes free of the parent on all sides (stage 4), it continues to increase in size and number of septa, but has for the most part the adult characters (pl. 11, figs. 2, 12). Small offsets of stage 4 may have as few as 10 major septa (pl. 9, fig. 7), although offsets of stage 3 may have as many as 16 (pl. 11, fig. 1) or more.

Individual development after becoming free of the parent corallite on all sides is shown statistically in figures 2 to 6 . Data are from 65 transverse sections of more than 25 corallites shown in the serial sections (pls. 9, 10).

In figure 2 the curved line represents average ontogenetic development of diameter by growth stages arbitrarily based on number of septa. Data for corallite 3 (holotype) are shown separately in figure 3 . The simple allometric pattern of growth indicates that the rate of increase in diameter increases with maturity. The spread of points around the line in figure 2 represents individual variation. Figure 4 shows the ontogenetic development of tabularium diameter. The graph is similar to figure 2 and the same remarks apply.

Figure 5 shows the development of the tabularium ratio (tabularium diameter $\left(d^{t}\right)$ divided by total diameter $(d))$. This ratio tends to decline with growth, as has been shown in some other rugose corals (Oliver, 1960 a, p. $71-73$, fig. 29), but variation is great and allometry cannot be distinguished.

Figure 6 indicates allometric development of diameter and tabularium diameter and differs from figures 2 to 5 in not being based on septal number classes.

\section{Subfamily STREPTELASMATINAE}

Genus BRIANTELASMA Oliver

Briantelasma Oliver, 1960 a, p. $89 ; 1960$ b, p. 6-7.

Type species.-Briantelasma americanum Oliver (1960a, p. 89-91, pl. 14, figs. 1-14). Reef facies of Coeymans limestone, Helderberg age, Early Devonian, Madison and Oneida Counties, New York. 


\section{Diagnosis.-}

Simple trochoid to cylindrical corals with subpinnately arranged major septa extending nearly to the axis; minor septa one-third to two-thirds as long. Marginarium formed by stereoplasmic infilling between irregularly dilated septa. Tabularium may be partly or entirely filled with stereome, especially in early growth stages. Tabulae strongly domed with axial depression, complete and closely spaced. Cardinal fossula present (Oliver, 1960b, p. 6)..

Remarks.-Previously recognized species of Briantelasma are from rocks of Early Devonian (Helderberg) age in New York and Maine. The specimens here described extend this range downward into the Silurian.

\section{Briantelasma sp.}

Plate 14, figures 8-12

Description.-Two small ceratoid horn corals have the following dimensions: length, 60 and $30 \pm \mathrm{mm}$; maximum diameter 13 and $12 \mathrm{~mm}$. Exterior smooth, with broad weak septal grooves and a few rugae. Calice (known only in section) moderately deep with septa projecting well in; fossula formed by short cardinal septum.

Transverse sections show a slight pinnate arrangement of the septa on either side of a short cardinal septum. The major septa extend nearly to the axis, the minor septa are one-fourth as long. The number of major septa $(n)$ in four transverse thin sections in the two specimens is as follows:

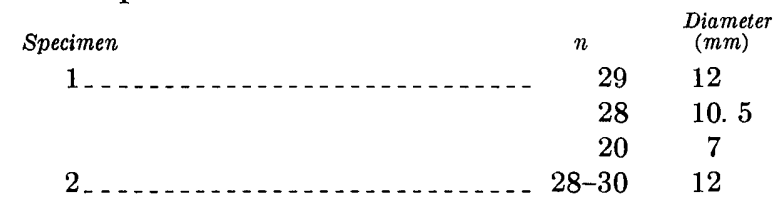

All septa are moderately dilated and tend to be rhopaloid. Axial and interseptal space is filled with stereome which is distinguishable from the septal tissue. A transverse thin section taken just below the calice shows a narrow open zone separating peripheral from axial zones of deposition.

Longitudinal sections show only the infilling stereome; tabulae cannot be distinguished. A chevron structure in the marginarium, similar to that described in other species of Briantelasma, is weakly developed in one of the two specimens.

Remarks.-Previously described species of Briantelasma have smooth calices with only slight or no septal projection; $B$. sp. differs by having prominent septal ridges on all sides. $B$. sp. is similar to $B$. mainense (Oliver, 1960b, p. 7) in septal shape and structure as seen in transverse section. It is similar to $B$. americanum (Oliver, 1960a, p. 89) in the extent of stereome infilling.
Material: Illustrated specimen, USNM 139462; traverse $B$, about 700 feet above base of formation; specimen 2, traverse $C$, about 500 feet above base of formation.

\section{Family LYKOPHYLLIDAE \\ Genus PHAULACTIS Ryder}

Phaulactis Ryder, 1926, p. 392; for synonymy, see Oliver, 1962.

Diagnosis.-Small to medium-sized trochoid to cylindrical solitary corals with numerous bilaterally arranged long septa; a wide zone of small arched dissepiments; and closely spaced incomplete arched tabulae. In early stages the septa are dilated and in lateral contact; in later stages the septa attenuate from the periphery inward; and in the final stage they may show little or no dilation.

Remarks.-Species of Phaulactis have been described from England, Gotland, the U.S.S.R., and Australia, from rocks ranging in age from upper Llandovery to Ludlow. Stumm (1962) and Oliver (1962) have described Phaulactis from Silurian rocks in Maine and the Squateck area, Quebec.

\section{Phaulactis sp.}

Plate 14 , figures 6,7

Description.-A single trochoid to ceratoid horn coral has the following dimensions: length, $20+\mathrm{mm}$; $\max -$ imum diameter, $15 \mathrm{~mm}$. Exterior and calice not known.

A transverse section shows the typical Phaulactis structure of axial dilation with septa partly in lateral contact, with peripheral attenuation. Twenty-seven major septa are present at a diameter of $12 \mathrm{~mm}$. The major septa extend nine-tenths the distance to the axis; minor septa are less than half as long.

A longitudinal section shows complete and incomplete roughly horizontal tabulae in the axial region, separated by a zone of septal dilation from the peripheral dissepimentarium. The dissepimentarium occupies nearly half the radius and is composed of many rows of inclined globose dissepiments.

Remarks.--The single specimen here referred to Phaulactis is similar to, and probably conspecific with, Phaulactis quebecensis Oliver (1962).

Material: Illustrated specimen, USNM 139464; traverse $B$, about 700 feet above base of formation.

\section{Family PTENOPHYLLIDAE Genus SPONGOPHYLLOIDES}

Spongophylloides Meyer, 1881, p. 109; Lang and Smith, 1927, p. 459 ; Butler, 1934, p. 541; Prantl, 1939, p. 133-134; Hill and Jones, 1940 , p. 180-181; Hill, 1956, p. 303.

Actinocystis Lindström, 1882, p. 21; 1896, p. 47-48; Wedekind, 1927, p. 44-45.

Type species.—Spongophylloides schumanni Meyer $(1881$, p. $109-110$, pl. 5 , figs. $12,12 \mathrm{a}-\mathrm{c})=$ Cystiphyllum grayi $\mathrm{E}$. and $\mathrm{H}$. 
(1851, p. 465), Silurian, Wenlockian, England (Lang, Smith, and Thomas, 1940, p. 121).

Diagnosis.-Solitary rugose corals with long, thin septa limited to the tabularium, which is made up of small incomplete tabulae. The dissepimentarium comprizes a zone of small inclined dissepiments, into which the septa do not penetrate.

Remarks.-Species of Spongophylloides have been described from the Middle and Upper Silurian of Europe and Maine. Lower Devonian occurrences have been reported but not verified.

\section{Spongophylloides sp.}

Plate 14, figures 1-5

Description.-Two small trochoid or ceratoid horn corals have the following dimensions: length, 20 and 30 $\mathrm{mm}$; maximum diameter, 11 and $12 \mathrm{~mm}$. Exterior smooth. Calice not known.

Transverse sections show a slight bilateral arrangement of the septa. The major septa extend most of the way to the axis; minor are half as long. The number of major septa $(n)$ in 4 transverse thin sections of the 2 individuals is as follows:

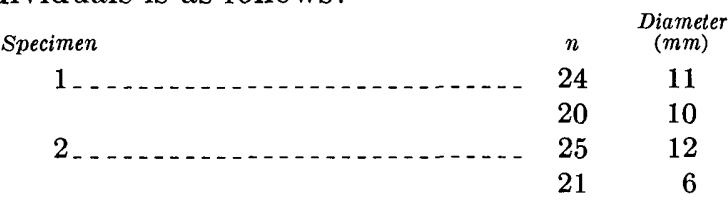

All septa are attenuate and limited to the tabularium. Marginarium is a lonsdaloid dissepimentarium formed by dilated dissepiments around part or all of the periphery in ephebic sections; the neanic marginarium and part of the early ephebic marginarium is a solid stereozone. The marginarium becomes more open with ontogenetic development.

Available longitudinal sections are poor, but they show steeply inclined thickened dissepiments in three or more rows and incomplete tabulae which form a concave pattern.

Remarks.-Spongophylloides sp. differs from previously described species of Spongophylloides by the possession of a marginarium that is partly a lonsdaloid dissepimentarium and partly a solid stereozone; it is probably a new species.

Material: Illustrated specimens USNM 139465, 139466; traverses $A$ and $C$, about 500 feet above the base of the formation.

\section{REFERENCES CITED}

Béland, Jacques, 1960, Preliminary report on Rimouski-Matapedia area, electoral districts of Rimouski, Matapedia, Bonaventure and Matane: Quebec Dept. Mines, Geol. Survey Br., Prelim. Rept. 430, 18 p., map.

Butler, A. J., 1934, On the Silurian corals Spongophylloides grayi (Edwards and Haime) and S. pusillus, sp. n.: Annals and Mag. Nat. History, ser. 10, v. 13, p. 540-548, pls. 17, 18.

Canada Geological Survey, 1957, Geology and economic minerals of Canada: 4th ed., Canada Geol. Survey, Econ. Geology Ser. 1, $517 \mathrm{p}$.

Crickmay, G. W., 1932, Evidence of Taconic orogeny in Mata pedia Valley, Quebec: Am. Jour. Sci., 5th ser., v. 24, p. 368-385.

Hill, Dorothy, 1935, British terminology for rugose corals: Geol. Mag., v. 72, p. 481-519.

1936, The British Silurian rugose corals with acanthine septa: Royal Soc. London Philos. Trans., Ser. B, no. 532, v. 226, p. $189-217$, pls. $29,30$.

1956, Rugosa, in Moore, R. C., ed., Treatise on invertebrate paleontology, pt. F, Coelenterata: Geol. Soc. America and Kansas Univ. Press, p. 233-324.

Hill, Dorothy, and Jones, O. A., 1940, The corals of the Garra beds Molong district, New South Wales: Royal Soc. New South Wales Jour. and Proc., v. 74, p. 175--208, pls. 2-8.

Kaljo, D., 1957, Codonophyllacea from the Ordovician and Llandoverian of the Baltic: Estonia Acad. Sci., Naturalists' Soc. Year book, v. 50, p. 153-168, pls. 16-17. [In Russian, brief summaries in Estonian and English.]

Lang, W. D., and Smith, Stanley, 1927, A critical revision of the rugose corals described by William Lonsdale in Murchison's "Silurian System": Geol. Soc. London Quart. Jour., v. 83, p. 448-491, pls. $34-37$.

Lang, W. D., Smith, Stanley, and Thomas, H. D., 1940, Index of Palaeozoic coral genera: London, British Mus. (Nat. History), $231 \mathrm{p}$.

Lindström, Gustav, 1882, Anteckningar om silurlagren p̊ Carlsöarne: Köngl. Vetensk.-Akad. Öfvers., Förhandl., v. 39 , no. 3 , p. 5-30.

1896, Beschreibung einiger Obersilurischer Korallen aus der Insel Gotland: Köngl. Svenska Vetensk.-Akad. Bihang Handl., v. 21, pt. 4, no. 7, p. 1-50, pls. 1-8.

Meyer, Georg, 1881, Rugose Korallen als ost- und westpreussische Diluvialgeschiebe: Phys. Gesell. Königsberg Schr., v. 22 , p. $97-110$, pl. 5 .

Oliver, W. A., Jr., 1960a, Rugose corals from reef limestones in the Lower Devonian of New York: Jour. Paleontology, v. 34 , p. 59-100, pls. 13-19.

1960b, Devonian rugose corals from northern Maine: U.S. Geol. Survey Bull. 1111-A, p. 1-23, pls. 1-5.

- 1962, Silurian rugose corals from the Lake Témiscouata area, Quebec: U.S. Geol. Survey Prof. Paper 430-B, p. 1119 , pls. 5-8. 
Prantl, Ferdinand, 1939, On the occurrence of the genus Spongophylloides Meyer in the Bohemian Silurian: Internat. Acad. Sci. Bohême Prague Bull., p. 133-137, 1 pl.

Ryder, T. A., 1926, Pycnactis, Mesactis, Phaulactis, gen. nov., and Dinophyllum Lind.: Annals and Mag. Nat. History, ser. 9 , v. 18 , p. $385-401$, pls. 9-12.

Smith, Stanley, and Tremberth, Reginald, 1929, On the Silurian corals Madreporites articulatus, Wahlenberg, and Madrepora truncata Linnaeus: Annals and Mag. Nat. History, ser. 10, v. 3 , p. $361-376$, pls. 7.8 .

Soshkina, E. D., 1937, Corals of the Upper Silurian and Lower Devonian of the eastern and western slopes of the Urals: U.S.S.R., Acad. Sci. Inst. Paléozoology Trans., v. 6, pt. 4, 112 p., 21 pls. [In Russian, English summary.]
Stumm, E. C., 1962, Silurian corals from the Moose River Synclinorium, Maine: U.S. Geol. Survey Prof. Paper 430-A, p. 1-9, pls. 1-4.

Wang, H. C., 1948, Notes on some rugose corals in the Gray collection, from Girvan, Scotland: Geol. Mag., v. 85, p. $97-106$, pl. 7 .

1950, A revision of the Zoantharia Rugosa in the light of their minute skeletal structures: Royal Soc. London Philos. Trans., Ser. B, no. 611, v. 234, p. 175-246, pls. 4-9.

Wedekind, Rudolf, 1927, Die Zoantharia Rugosa von Gotland (bes. Nordgotland): Sweden, Geol. Undersökning, Ser. Ca, no. 19,95 p., 30 pls. 



\section{INDEX}

[Italic numbers indicate descriptions]

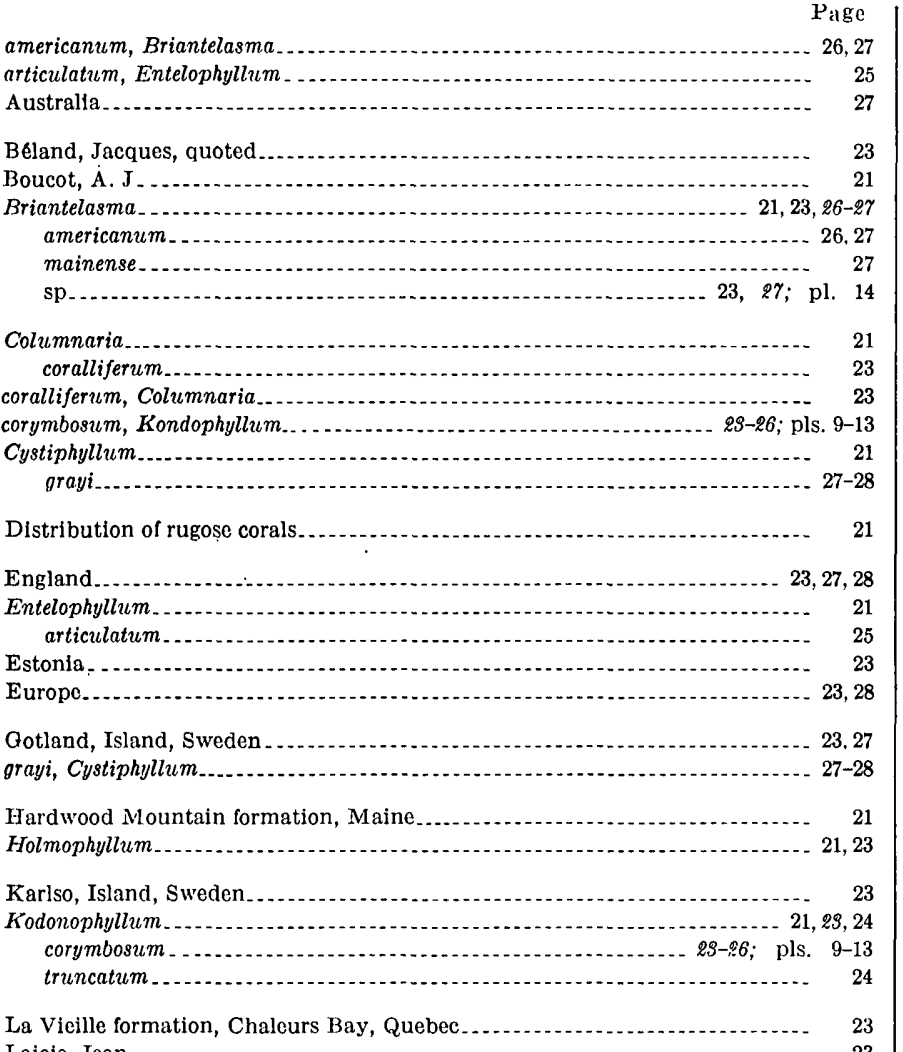

a Vieille formation, Chaleurs Bay, Quebec

Lajoie, Jean.
Page

Lobster Lake formation, Maine

Location of fossile areas in Maine and Quebec.

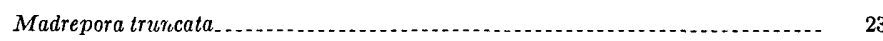

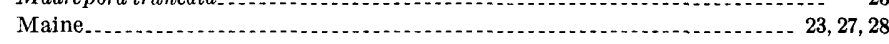

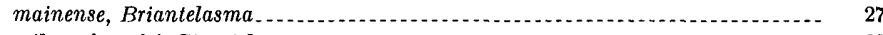

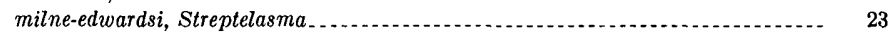

Mont Wissick formation, Quebec....... 21

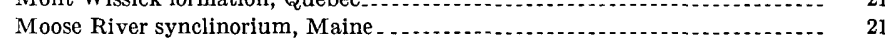

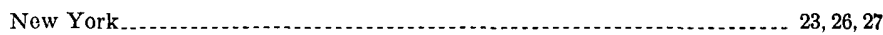

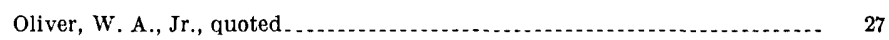

Phaulactis _............................ 21, 23, 27

quebecensis

sp

Pinckney, William C., Jr

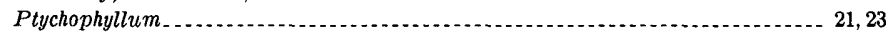

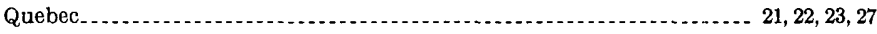

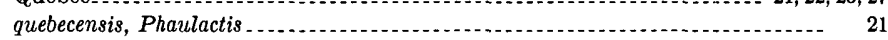

Sayabec formation............................................................. 21, 23, 24

schumanni, Spongophylloides

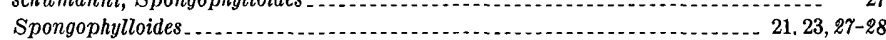

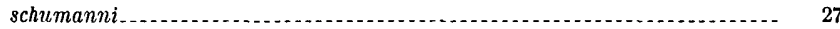

sp............................... 28; pl. 14

Squateck area, Quebec

21
Streptelasma

Témiscouata, Lake, area . ................................................. 21, 22

Terminology of corallum development in rugose corals

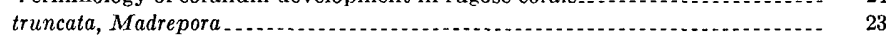

truncatum, Kodonophyllum .

Tryplasma

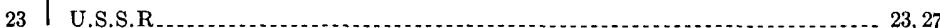



PLATES 1-4 


\section{PLATE 1}

[All figures $\times 4$ unless otherwise indicated]

Figures 1, 2. Phaulactis sp. A (p. 2).

1. Transverse section of a specimen showing septal thickening in cardinal quadrants. Figured specimen USNM 139430, Cranbourne limestone, USGS loc. 3611-SD.

2. Another transverse section of the same specimen.

3-5. Holmophyllum pseudocarinatum n. sp. (p. 4).

3. Transverse section showing edges of acanthine septa and edges of tabulae. Holotype, USNM 139439, Hardwood Mountain formation, USGS loc. 2822-SD.

4. Longitudinal section of same specimen showing wide dissepimentarium, oblique acanthine septa, and concave tabulae.

5. Another longitudinal section of same specimen showing side view of calyx.

6-8. Entelophyllum sp. A (p. 3).

6. Tangential section showing carinate septa and part of dissepimentarium. Figured specimen USNM 139432. Hardwood mountain formation, USGS loc. 3484-SD, $\times 2$.

7. Transverse section showing carinate septa. Figured specimen USNM 139433. Same occurrence as original of figure 6.

8. Another transverse section. USNM 139434. Cranbourne limestone, USGS loc. 3611-SD.

9. Spongophylloides sp. A (p. 3).

9. Transverse section showing lonsdaleioid dissepimentarium. Figured specimen USNM 139437. Hardwood Mountain formation, USGS loc. 3484-SD. 


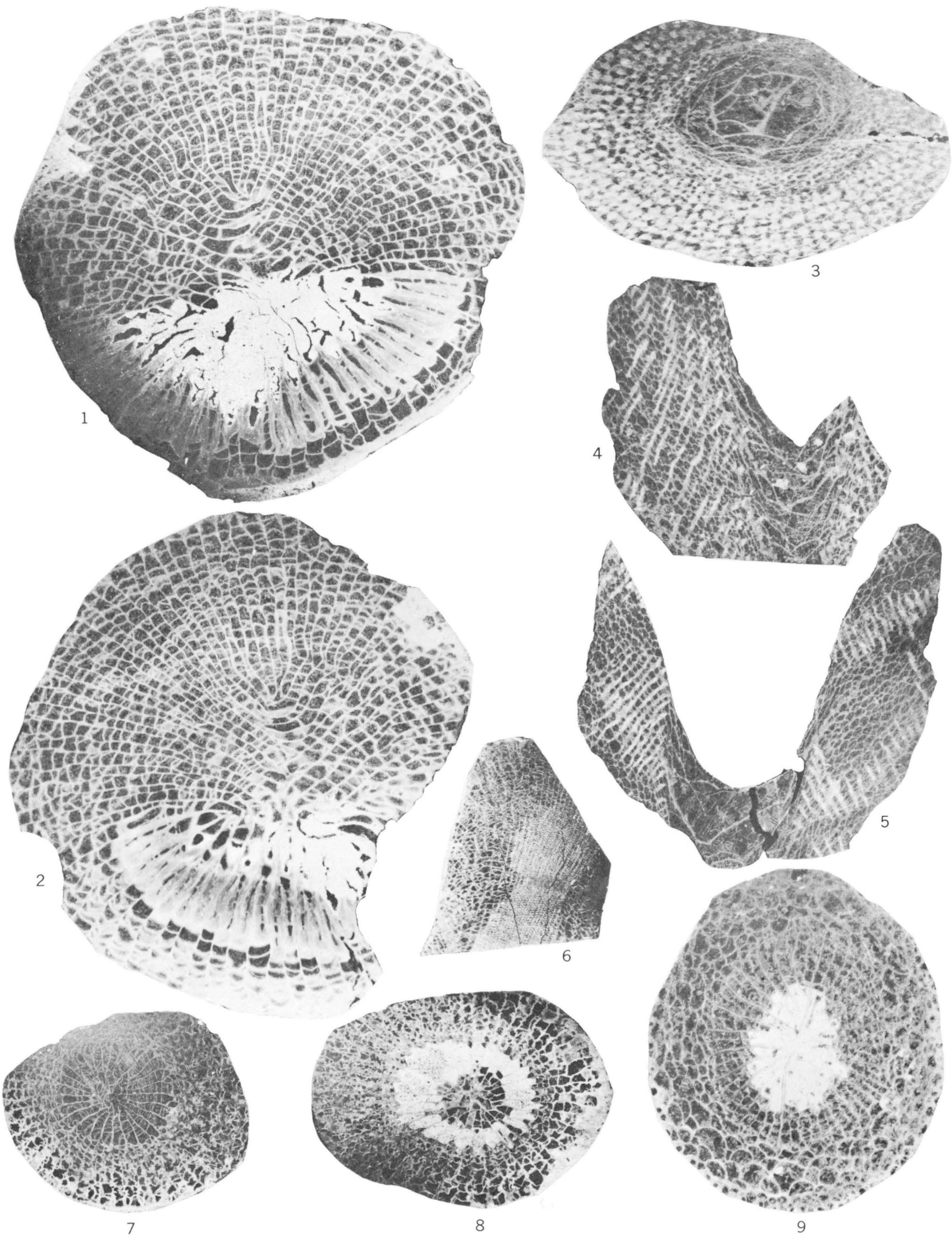

PHAULACTIS, HOLMOPHYLLUM, ENTELOPHYLLUM, AND SPONGOPHYLLOIDES 


\section{PLATE 2}

Figure 1. Streptelasma? sp. A (p. 2).

[All figures $\times 4$ unless otherwise indicated]

1. Transverse section showing septa, peripheral stereozone, and possible axial structure. Figured speciman USNM 139427. Cranbourne limestone, USGS loc. 3611-SD.

2. Cystiphyllum sp. A (p. 3).

2. Transverse section showing dissepiments and degenerate acanthine septa. Figured specimen USNM 139438. Lobster Lake formation, USGS loc. 1417-SD. $\times 2$.

3-5. Ptychophyllum sp. A (p. 3).

3. Transverse section showing septa thickening axially and producing axial whorls. USNM 139435 . Hardwood Mountain formation, USGS loc. 3484-SD.

4. Another transverse section of the same specimen.

5. Incomplete transverse section showing tabularium. USNM 139436. Cranbourne limestone, USGS loc. 3611-SD.

6-8. Streptelasma? sp. C (p. 2).

6. Transverse section, late neanic stage. Figured specimen USNM 139429. Lobster Lake formation, USGS loc. 1417-SD. $\times 2$.

7. Transverse section ephebic stage of same specimen. $\times 2$.

8. Longitudinal section of same specimen showing sinuous tabulae.

9-11. Entelophyllum parvum n. sp. (p. 2).

9. Longitudinal section showing axial and periaxial parts of tabularium and narrow dissepimentarium. Holotype USNM 139431. Hardwood Mountain formation, USGS loc. 2822-SD.

10. Transverse section of same specimen showing position of probable connecting talon.

11. Another transverse section of same specimen showing thin noncarinate septa.

12, 13. Streptelasma? sp. B (p. 2).

12. Transverse section cut near base of calyx showing peripheral stereozone and tapering septa. Figured specimen USNM 139428. Hardwood Mountain formation, USGS loc. 3484-SD. $\times 2$.

13. Transverse section cut through calyx of same specimen.

14-16. Tryplasma nordica n. sp. (p. 4).

14. Transverse section showing acanthine septa. Holotype USNM 139440. Lobster Lake formation, USGS loc. 1417-SD.

15. Transverse section of another specimen. Paratype USNM 139441. Same occurrence as original of figure 14. $\times 2$.

16. Longitudinal section of holotype, $\times 2$. 


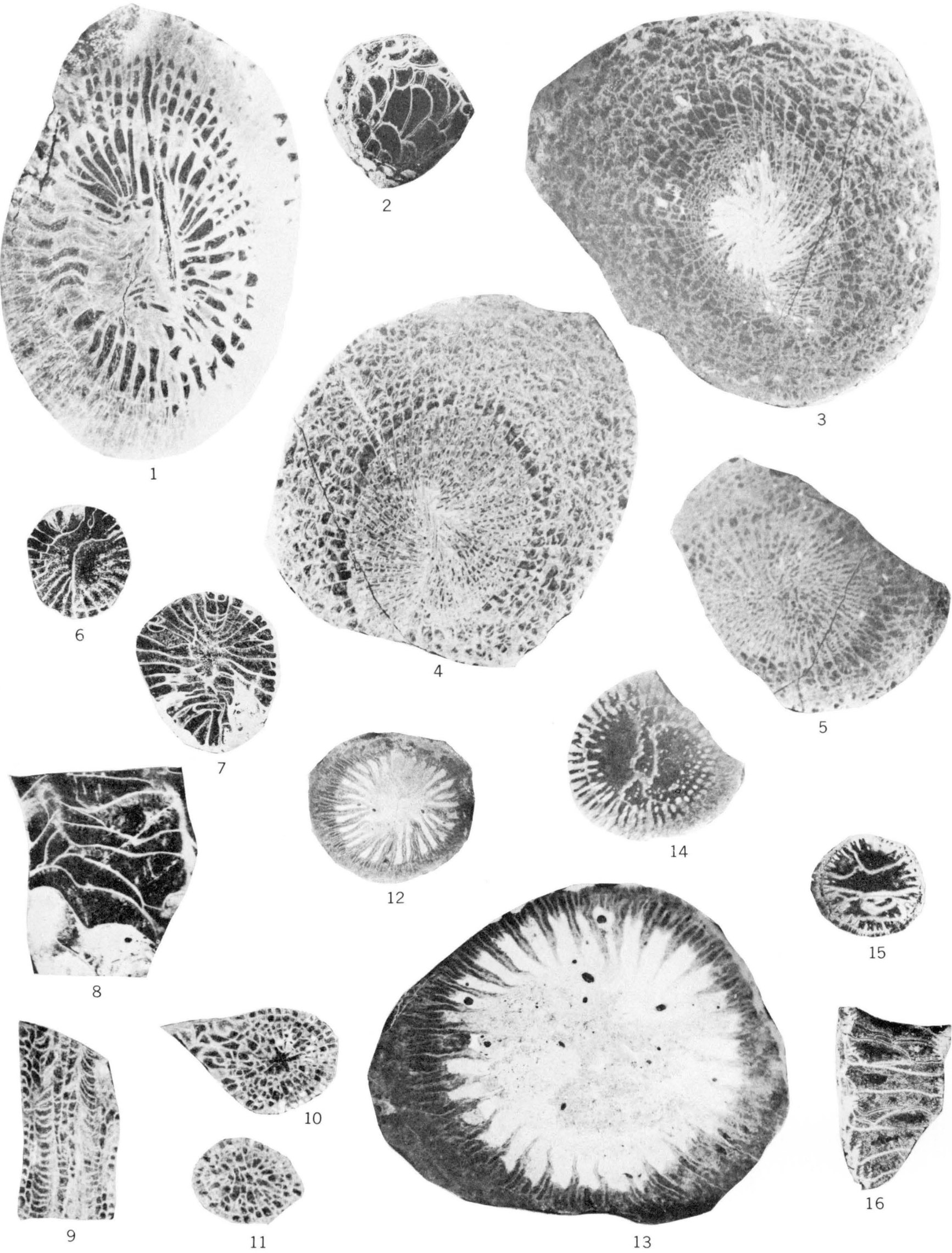

STREPTELASMA, CYSTIPHYLLUM, PTYCHOPHYLLUM, ENTELOPHYLLUM, AND TRYPLASMA 


\section{PLATE 3}

[All figures $\times 4$ ]

Figdres 1, 2. Astrocerium intermittens n. sp. (p. 5).

1. Longitudinal section of holotype showing evenly spaced tabulae and intermittently developed septal spines. Holotype USNM 139445, Hardwood Mountain formation, USGS loc. 3484-SD.

2. Transverse section of same specimen showing septal spines well developed in some corallites, absent in others.

3, 4. Astrocerium intermittens magnum n. subsp. (p. 5).

3. Longitudinal section showing tabulae and short septal spines. Holotype USNM 139446. Hardwood Mountain formation, USGS loc. 2728-SD.

4. Transverse section of same specimen.

5, 6. Propora nordica n. sp. (p. 4).

5. Transverse section showing tabulate areas with septal spines and intertabulate areas. Holotype USNM 139442. Cranbourne limestone, USGS loc. 3611-SD. .

6. Longitudinal section of same specimen showing domed dissepiments in intertabulate areas.

7, 8. Arcturia angularis n. sp. (p. 6).

7. Transverse section showing polygonal or subrounded corallites with connecting tubules. Holotype USNM 139449, Hardwood Mountain formation, USGS loc. 3484-SD.

8. Longitudinal section of same specimen showing tubules and complete tabulae.

9, 10. Favosites niagarensis Hall (p. 5).

9. Transverse section showing polygonal corallites. Hypotype USNM 139447, Hardwood Mountain formation, USGS loc. 3488-SD.

10. Longitudinal section showing mural pores and relatively widely spaced tabulae. Hypotype USNM 139448, same occurrence as original of figure 9. 

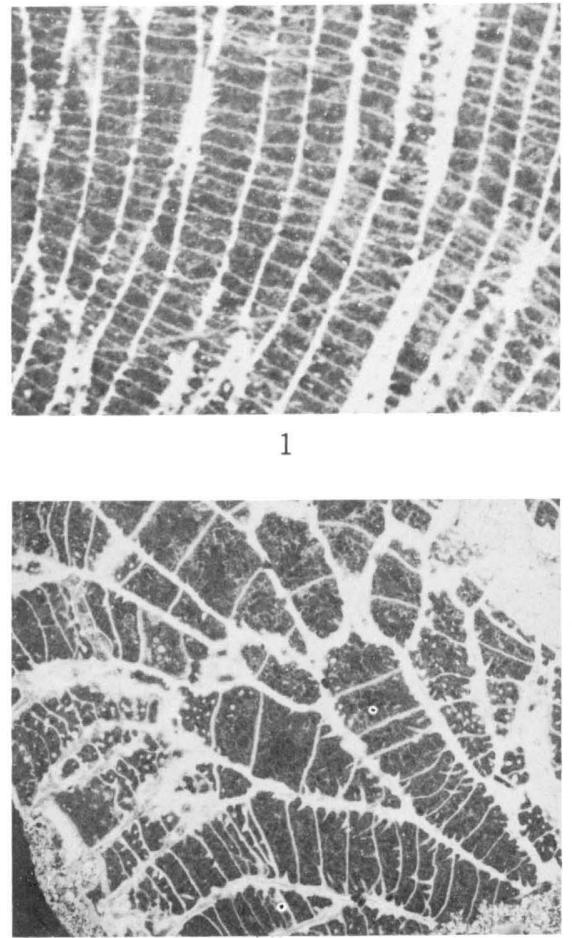

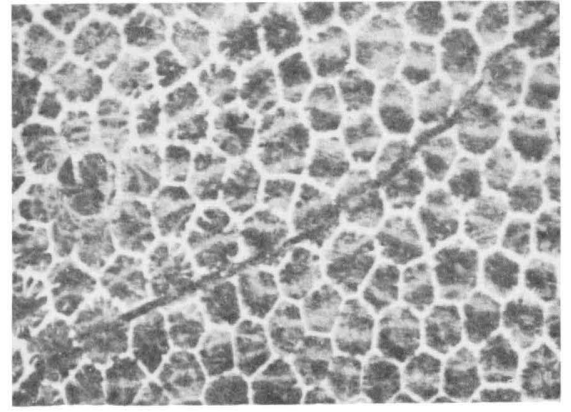

2

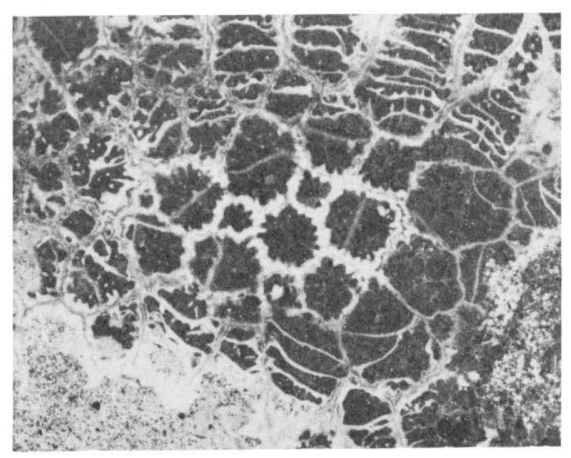

4

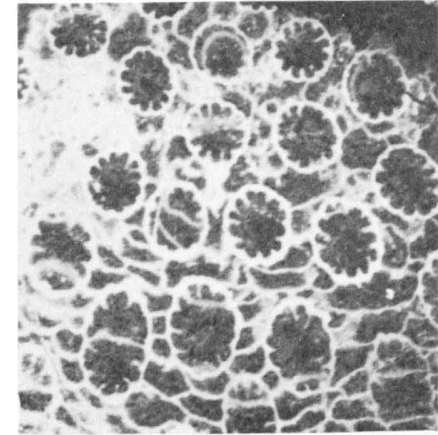

5

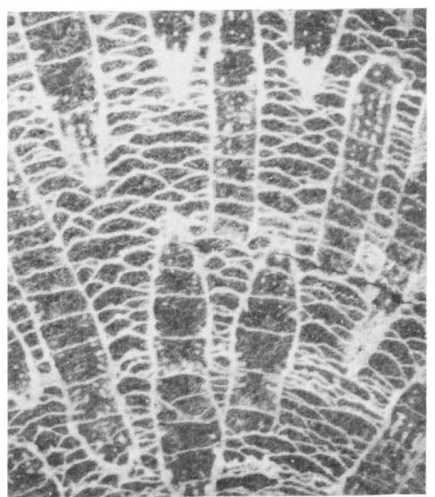

6

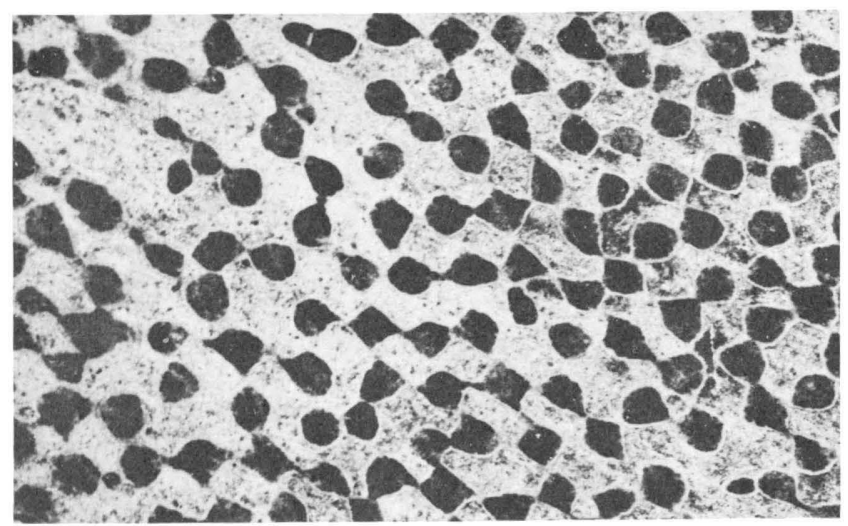

7

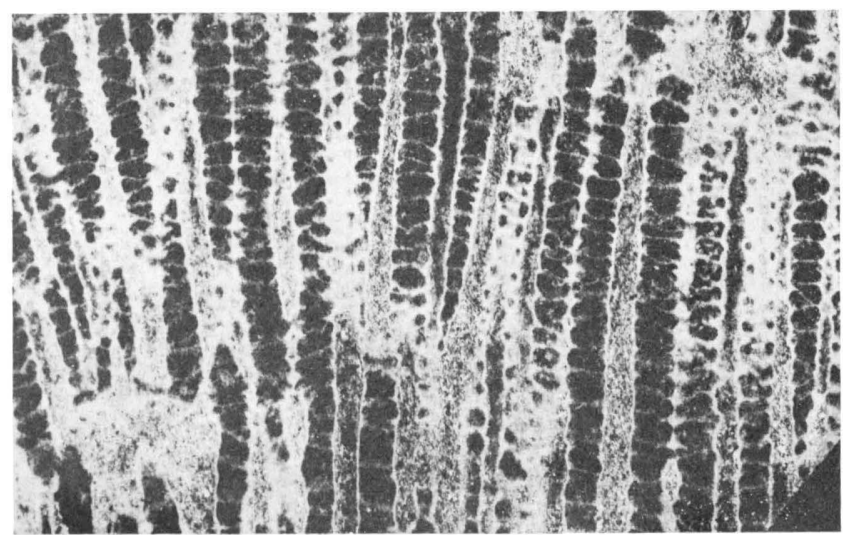

8
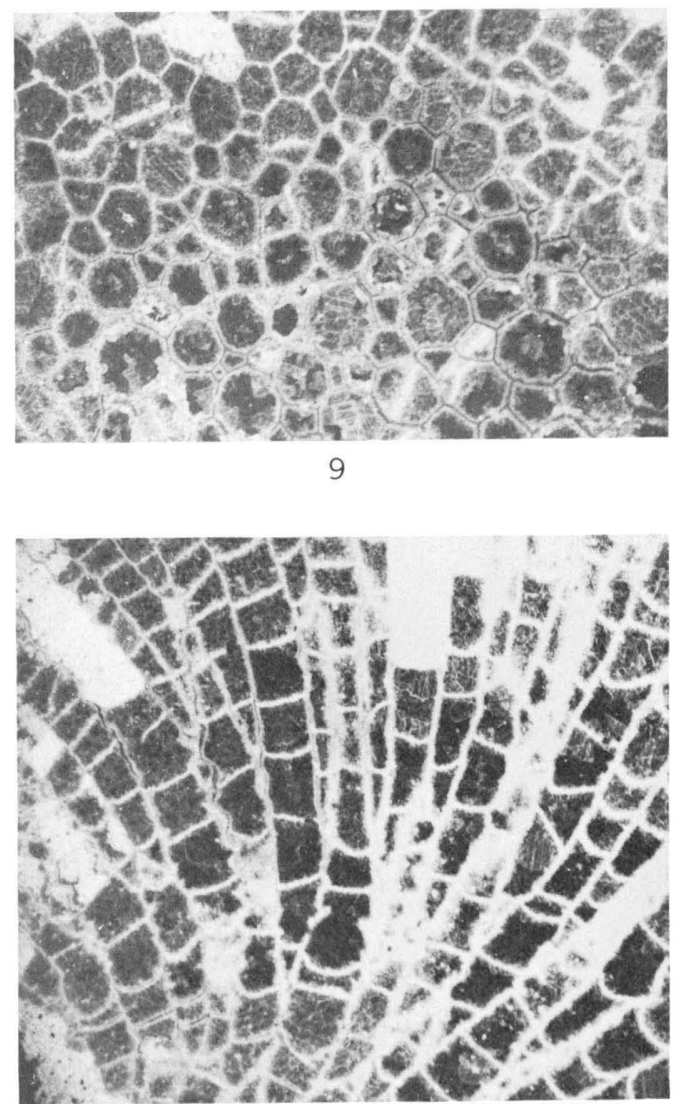

10

ASTROCERIUM, PROPORA, ARCTURIA, AND FAVOSITES 


\section{PLATE 4}

[All figures $\times 4$ ]

Fig URES 1, 2. Heliolites interstinctus occidentalis n. subsp. (p. 5).

1. Transverse section showing tubuli and tabulate areas with short septal ridges. Holotype USNM 139444. Hardwood Mountain formation, USGS loc. 3496-SD.

2. Longitudinal section of same specimen showing widely spaced tabulae.

3-5. Cystihalysites sp. cf. C. amplitubulata (Lambe) (p. 6).

3. Transverse section showing elliptical, thick-walled macrocorallites and recrystallized microcorallite areas between them. Figured specimen USNM 139450, Hardwood Mountain formation, USGS loc. 3496-SD.

4. Transverse section showing long ranks of corallites. Figured specimen USNM 139451, Hardwood Mountain formation, USGS loc. 3400-SD.

5. Longitudinal section of same specimen showing horizontal tabulae in macrocorallites and cystose tabellae in microcorallites.

6, 7. Syringopora multitubulosa n. sp. (p. 6).

6. Longitudinal section showing dissepiments and septal spines. Holotype USNM 139452, Hardwood Mountain formation, USGS loc. 3484-SD.

7. Transverse section of same specimen showing connecting tubules.

8, 9. Plasmopora franklinensis $\mathrm{n}$. sp. (p. 4).

8. Longitudinal section showing tabulate and intertabulate areas. Holotype USNM 139443, Hardwood Mountain formation, USGS loc. 3484-SD.

9. Transverse section of same specimen showing septal ridges. 

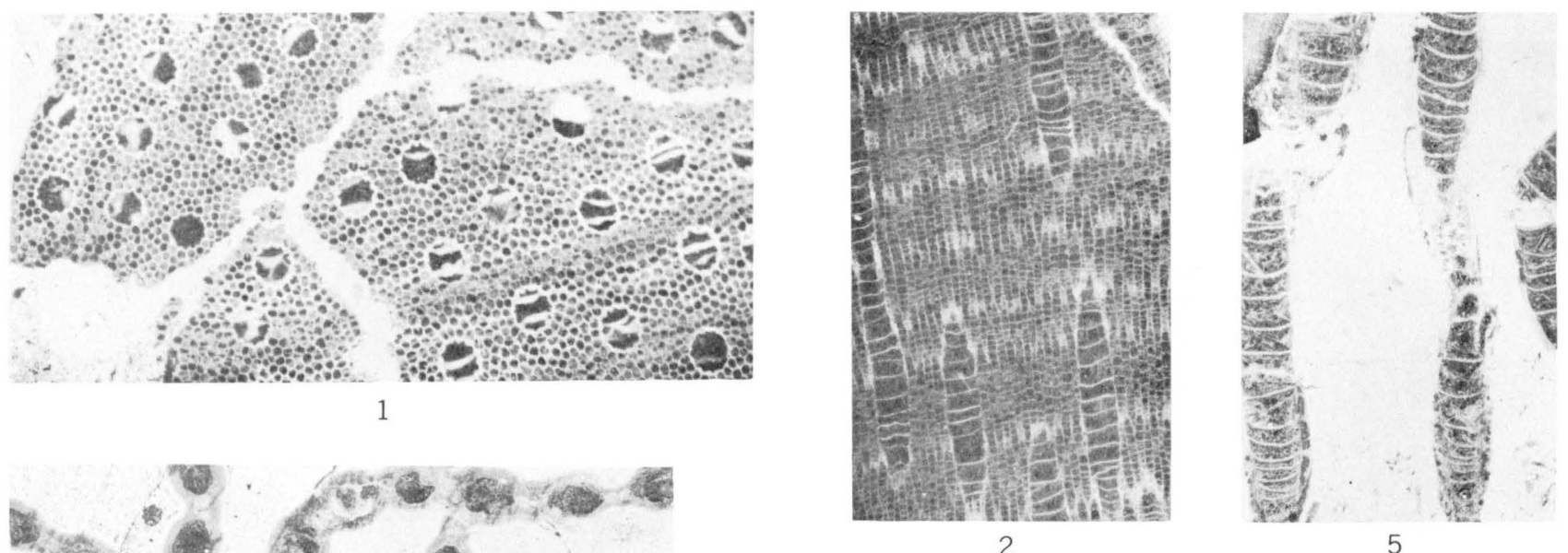
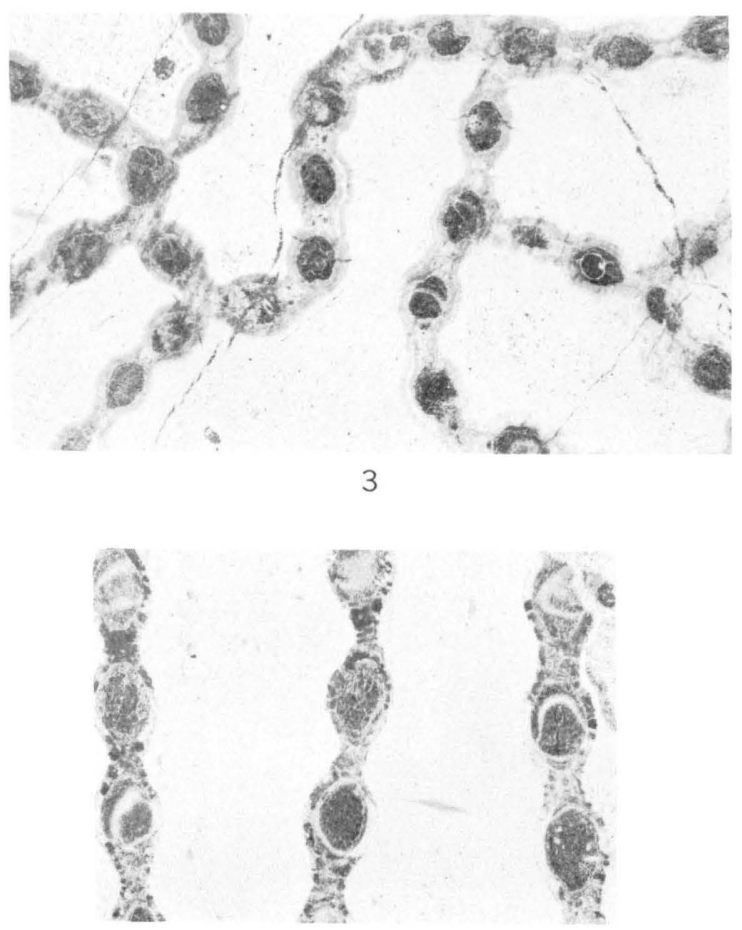

4

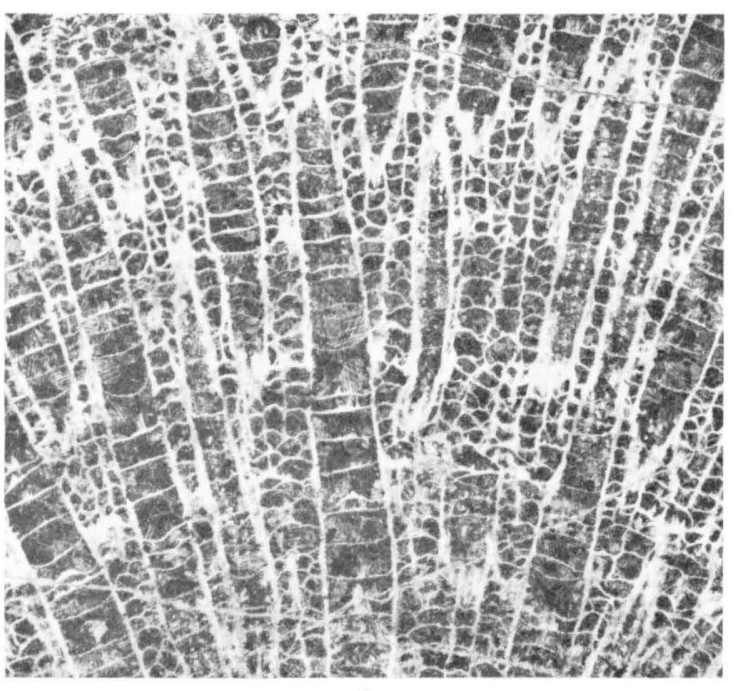

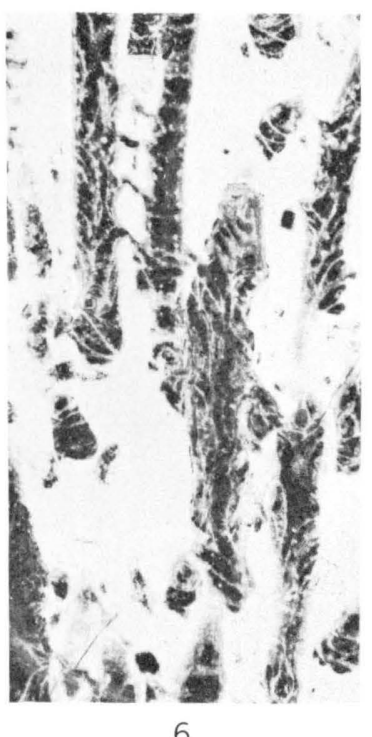

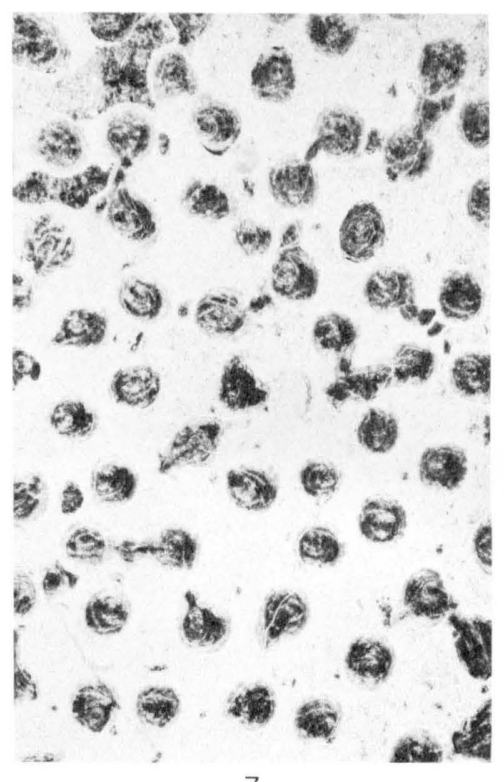

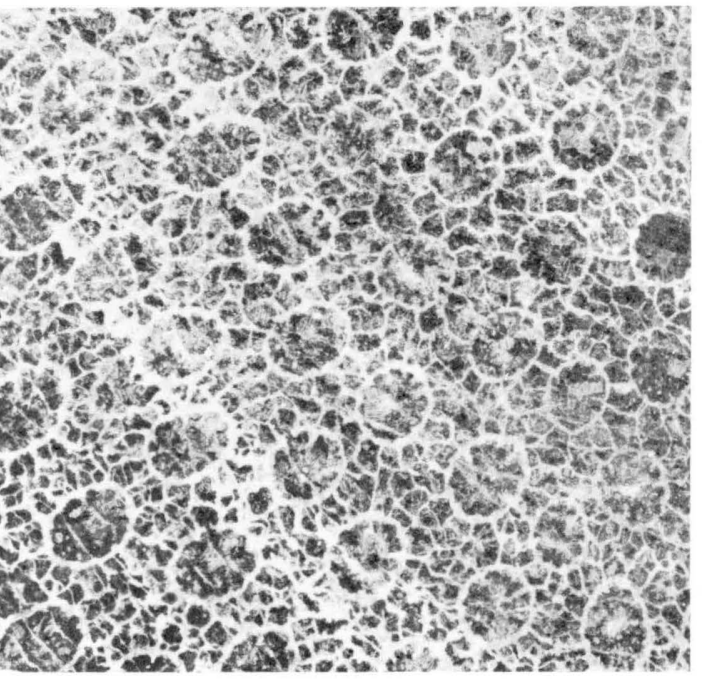

HELIOLITES, CYSTIHALYSITES, SYRINGOPORA, AND PLASMOPORA 


\section{PLATES 5-8}




\section{PLATE 5}

[All figures $\times 2.5$ unless otherwise indicated]

Figures 1-5. Phaulactis quebecensis n. sp. (p.12).

1-4. Holotype, USNM 139220; 1, 2, transverse and longitudinal thin sections of late ephebic stage, transverse section taken at base of longitudinal section; 3,4 , parts of figures 1 and $2(\times 10)$.

5. Paratype, USNM 139221 ; transverse thin section through middle ephebic stage.

6, 7. Holmophyllum sp. $1, \times 5$, USNM 139458, 139459 (p.15). Transverse and longitudinal thin sections of different individuals. 


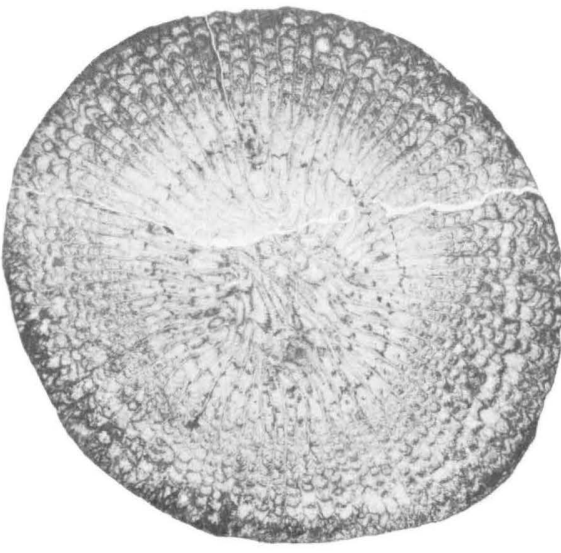

1

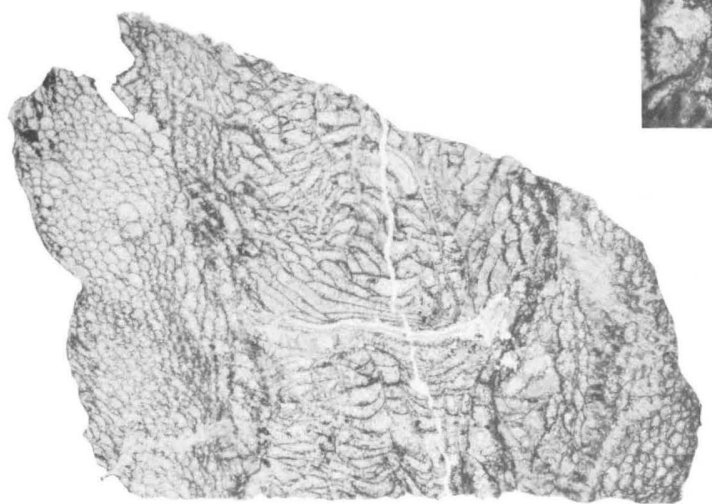

2

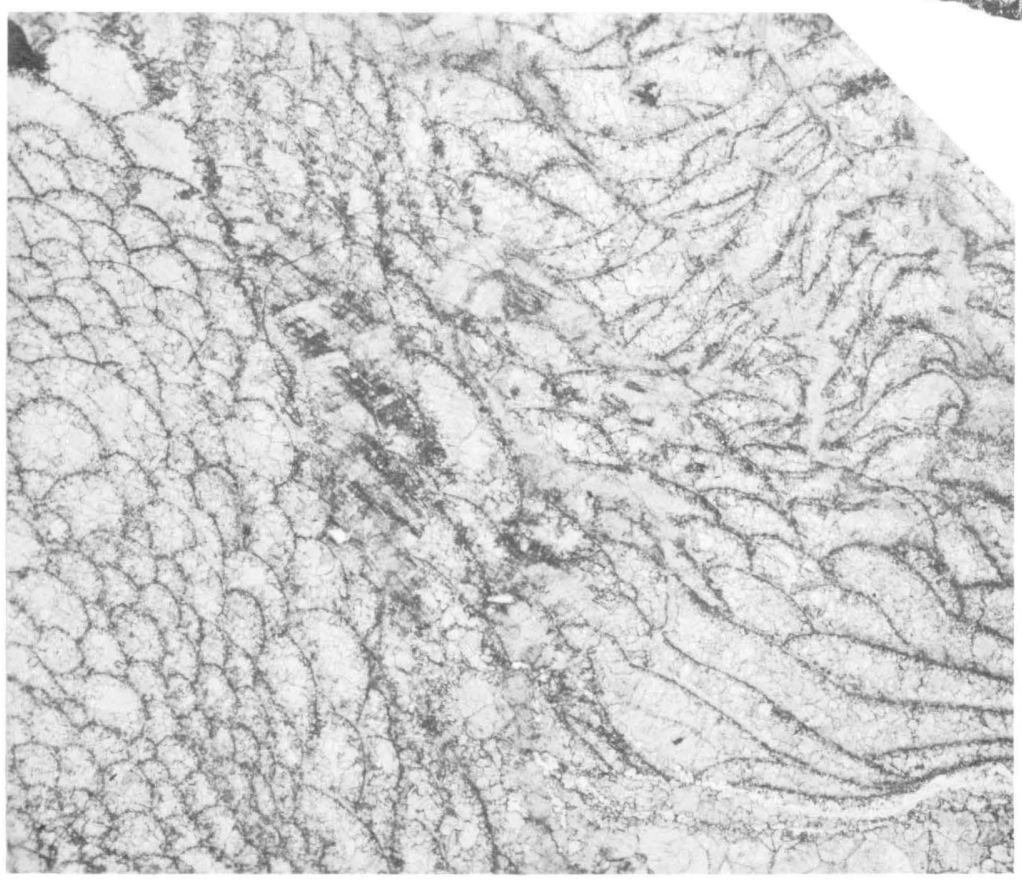

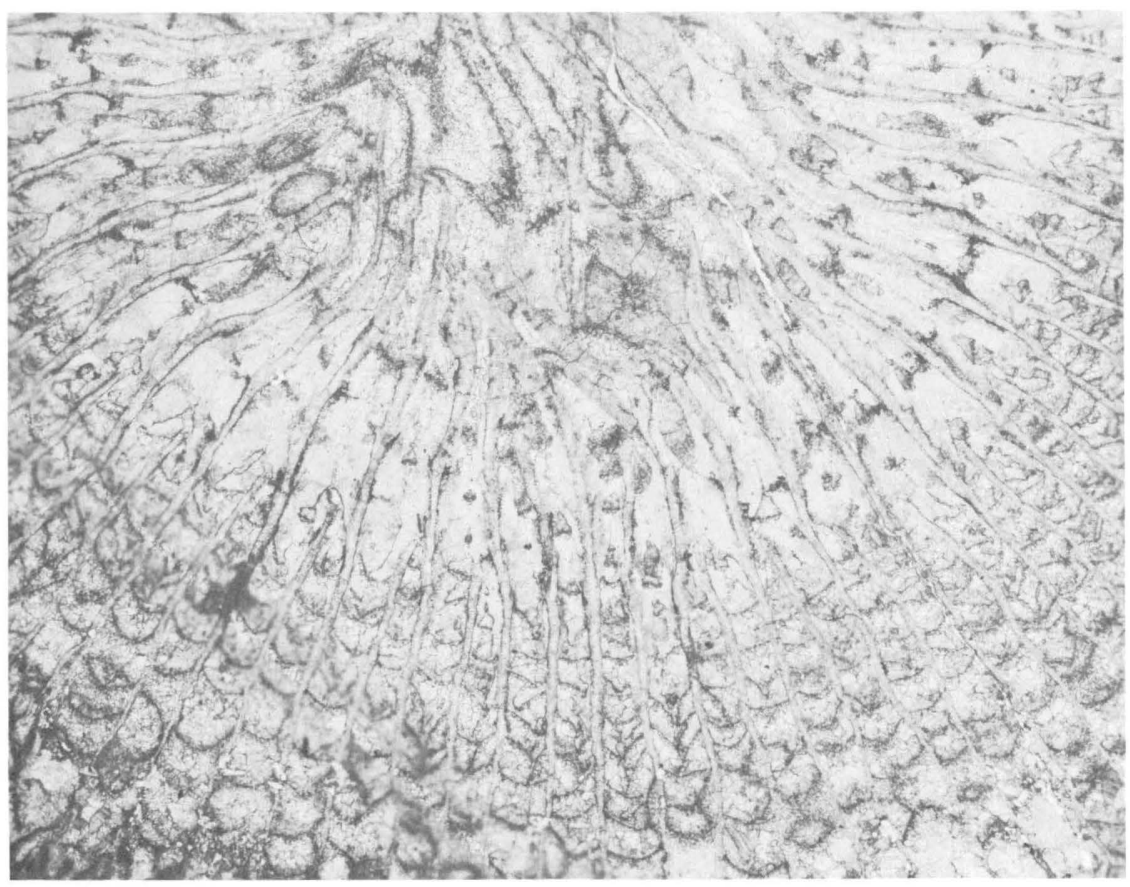

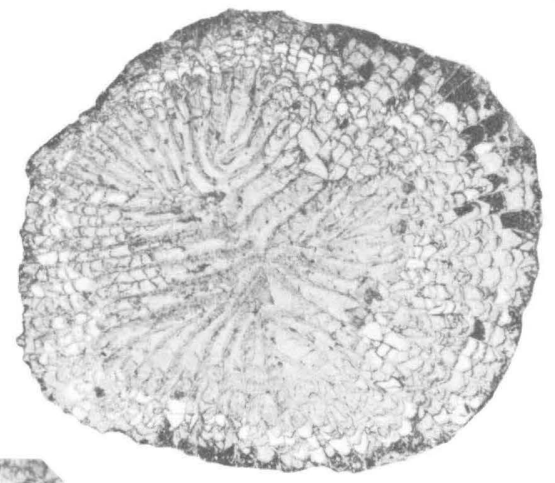

5

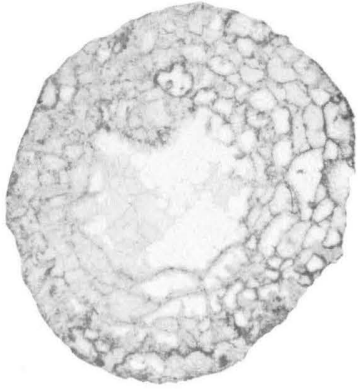

6

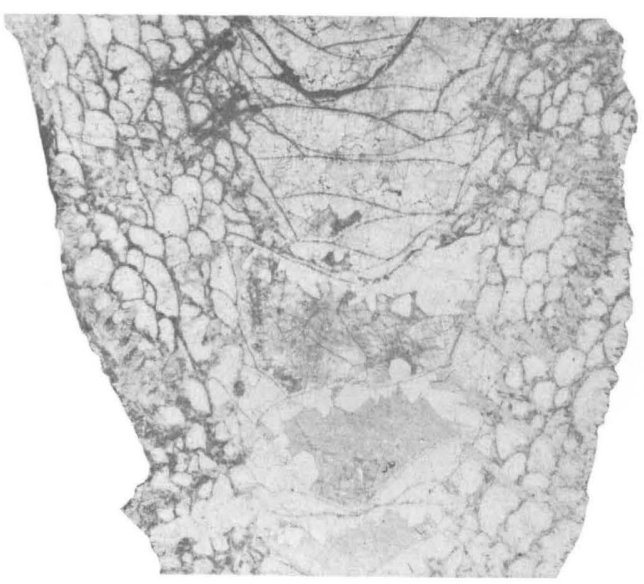

PHAULACTIS QUEBECENSIS N. SP. AND HOLMOPHYLLUM SP. 1 


\section{PLATE 6}

[All figures $\times 2.5$ unless otherwise indicated]

FigURes 1-10. Phaulactis quebecensis n. sp. (p.12).

1-3. Paratype, USNM $139222 ; 1,2$, transverse thin sections of middle and early ephebic stages; 3 , longitudinal thin section.

4-6. Paratype, USNM 139223; 4, longitudinal thin section; 5 , transverse thin section through late neanic stage; 6 , part of figure $5(\times 10)$.

7-9. Paratype, USNM 139224; 7, 8, transverse thin sections through middle and early ephebic stages; 9 , part of figure $7(\times 10)$.

10. Paratype, USNM 139225; transverse thin section through ephebic stage.

11, 12. Entelophyllum sp. 1, $\times$ 5, USNM 139240 (p.15). Transverse and longitudinal thin sections. 

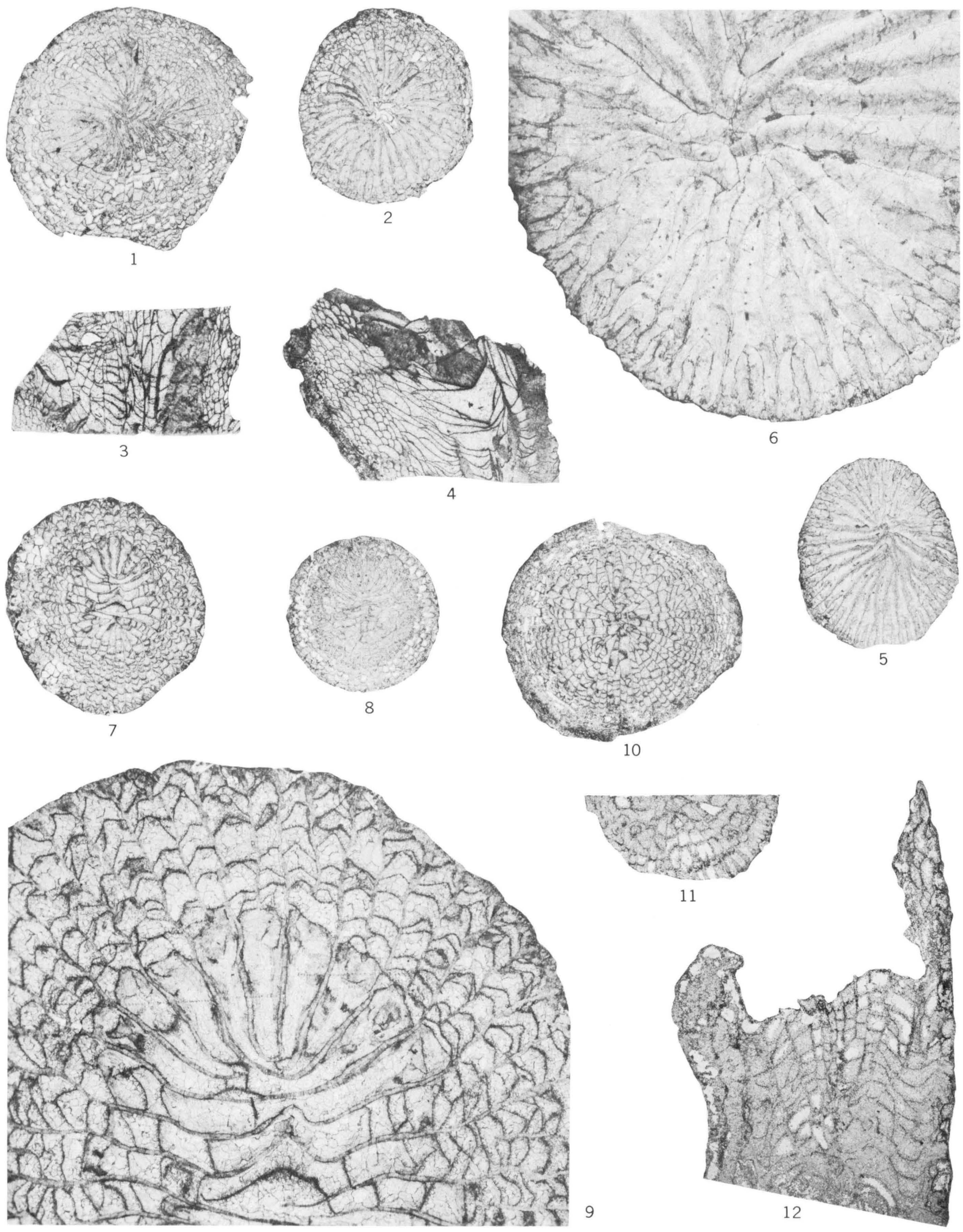

PHAULACTIS QUEBECENSIS AND ENTELOPHYLLUM SP. 1 


\section{PLATE 7}

[All figures $\times 5$ unless otherwise indicated]

Figures 1-7. Tryplasma nordica Stumm (p.13).

1-3. USNM 139228; 1, 2, transverse thin sections; 3 , part of figure 2 ( $\times 50)$.

4. USNM 139229; longitudinal thin section.

5-7. USNM $139230 ; 5,6$, longitudinal and transverse thin sections, transverse section taken just below the longitudinal section; 7 , part of $5(\times 50)$.

8, 9. Holmophyllum sp. 1, USNM 139238 (p. 15). Transverse and longitudinal thin sections. 

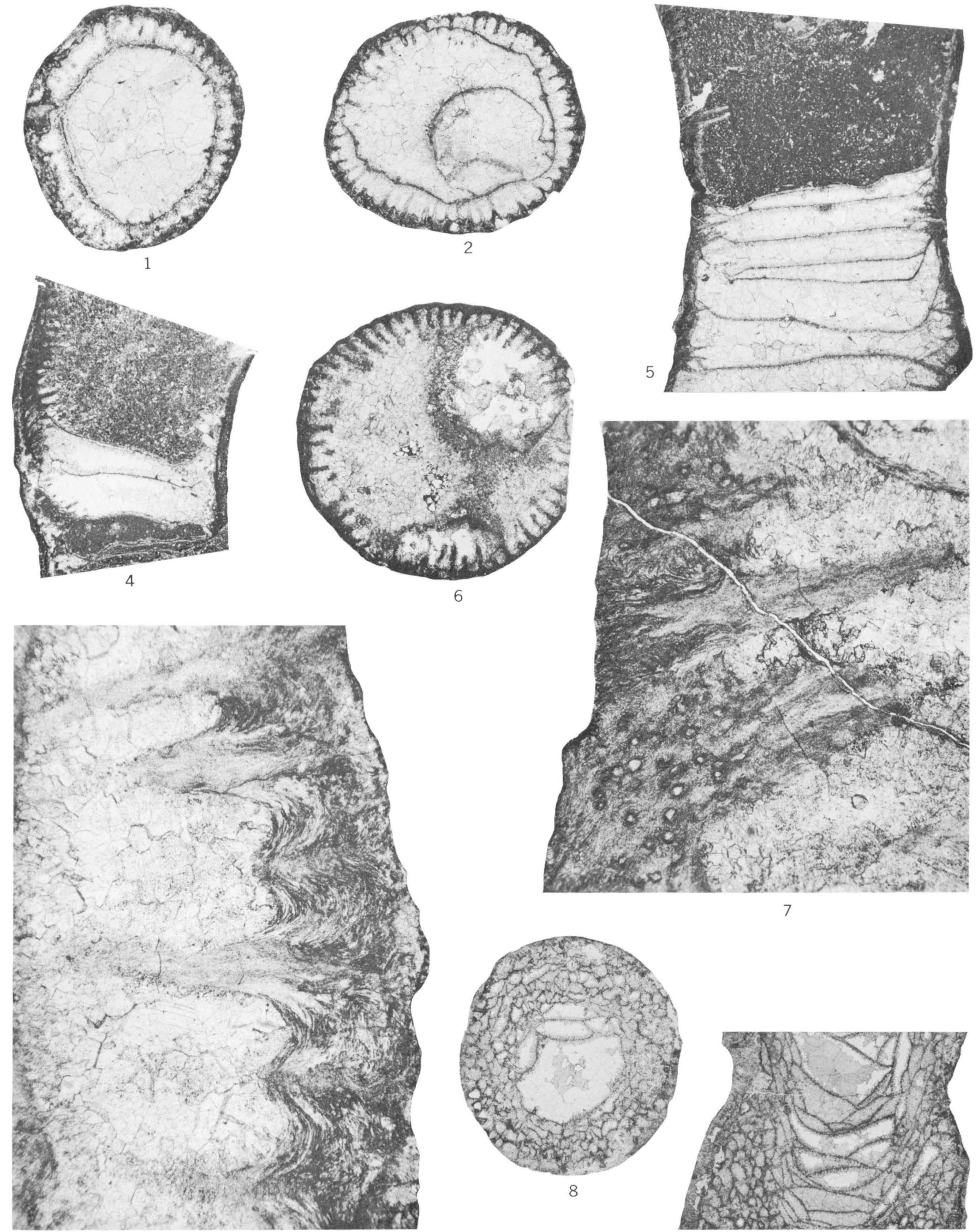

3

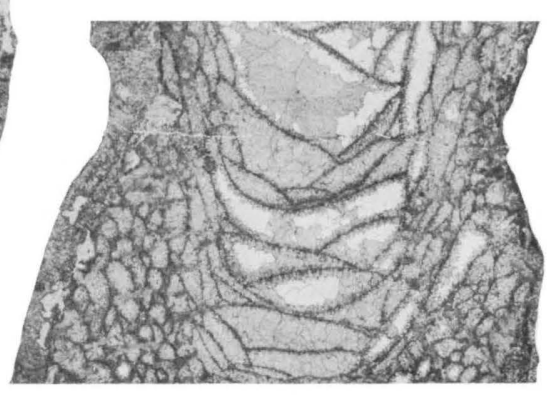

TRYPLASMA NORDICA STUMM AND HOLMOPHYLLUM SP. 1 


\section{PLATE 8}

[All figures $\times 15$ unless otherwise indicated]

Figures 1-8. Columnaria? coralliferum (Hall) (p.14).

1,2. USNM 139232; longitudinal section showing deeply concave tabulae, and transverse section.

3, 4. USNM 139233; 3, longitudinal thin section showing local development of dissepiments ; 4 , part of figure $3(\times 50)$.

5, 6. USNM 139234; transverse thin section and part of same $(\times 50)$.

7 , 8. USNM 139235; transverse thin section and part of same $(X 50)$. 

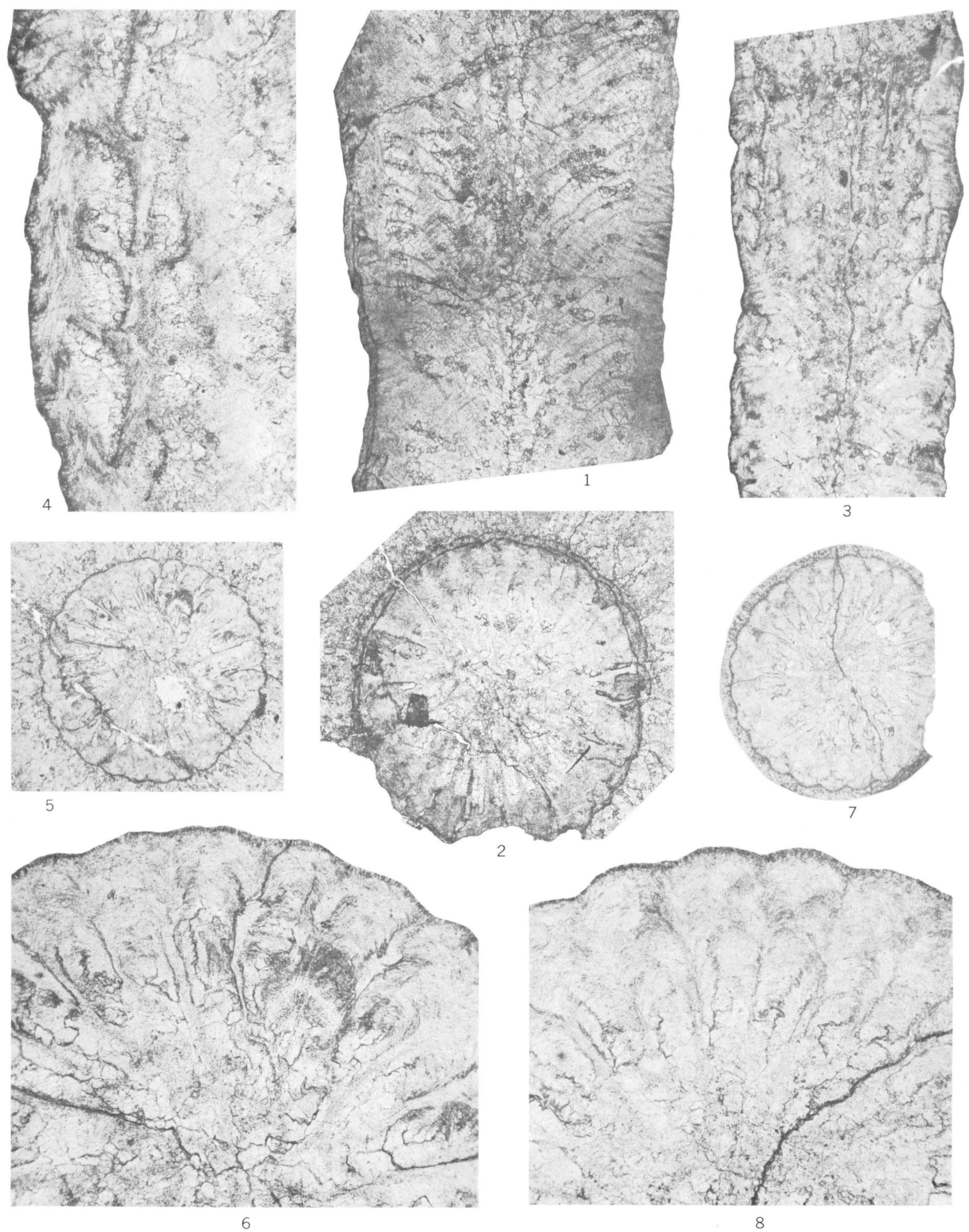

COLUMNARIA? CORALLIFERUM (HALL) 
PLATES 9-14 


\section{PLATE 9}

FiguRes 1-7. Kodonophyllum corymbosum n. sp., USNM 139460 (p. 23)

1-3. Serial transverse thin sections of principal clump of corallites $(\times 1.5)$. Key to individual corallites is given below. Figure 1 is the youngest section.

4-6. Longitudinal thin sections ( $\times 4$ ) of corallites 1,4 , and 3, respectively. Corallite 3 is the holotype. All three longitudinal sections were taken just below the transverse section shown in figure 3 and above the sections on plate 10 .

7. Transverse section $(\times 20)$ of small, stage 4 offset, located between corallites 1 and 3 (pl. 10, fig. 4).
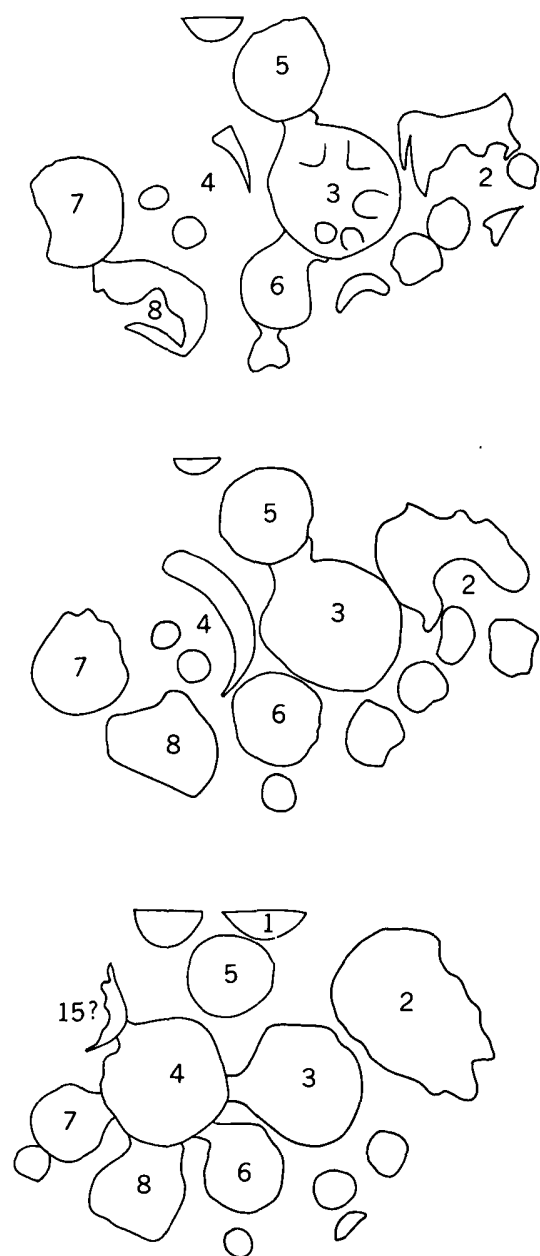

KEY TO SERIAL SECTIONS; PLATE 9, FIGURES 1-3, REDUCED 1/2

Numbers on the figures mark corallites that can be seen in more than one section. The three sections were cut at about 5-mm intervals and are in descending order.

Figures $1-5$ on plate 10 are part of the same series, but are separated from these 3 sections by a distance of $17 \mathrm{~mm}$ in which the longitudinal sections, figures $4-6$, were cut. 
GEOLOGICAL SURVEY
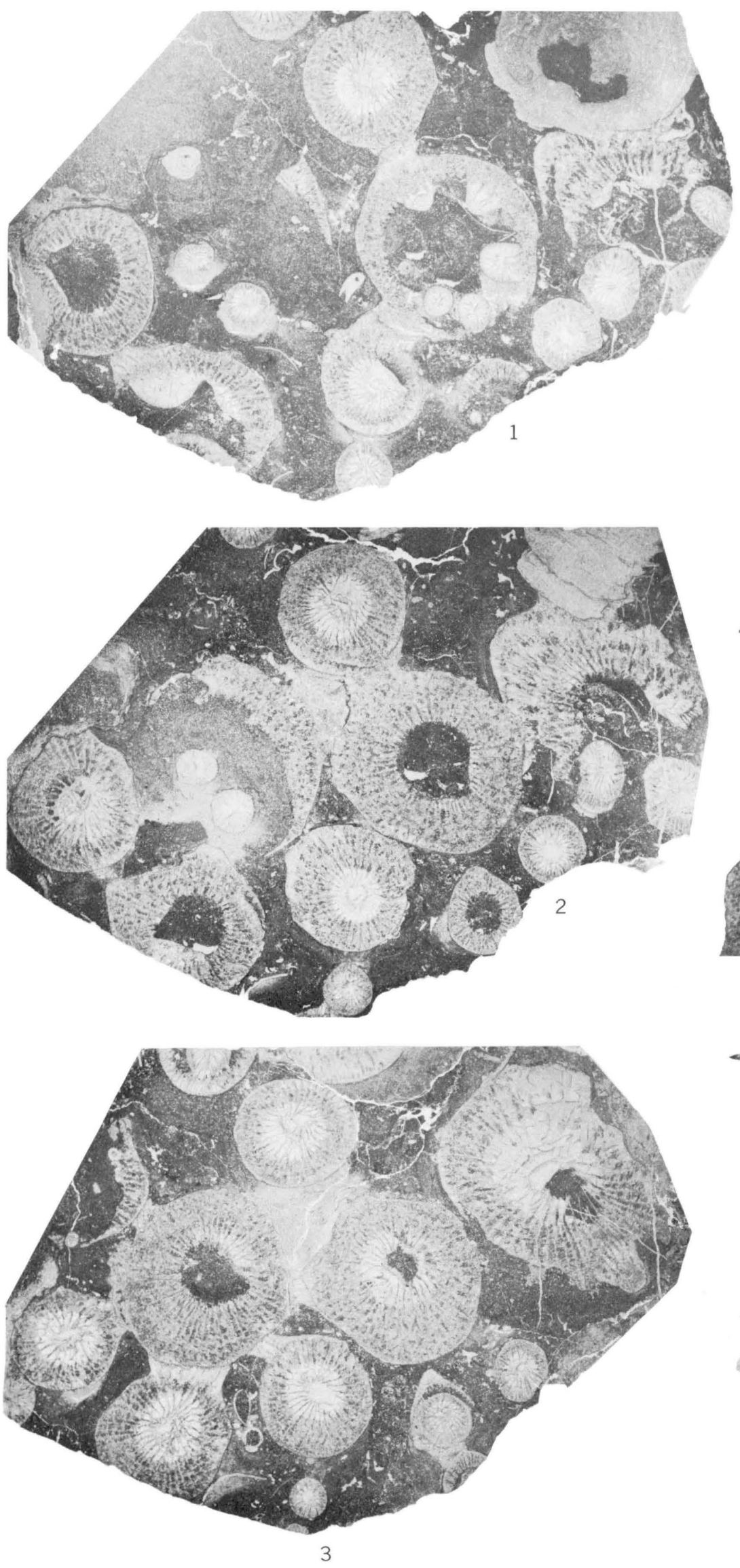

PROFESSIONAI PAPER 430 PLATE 9
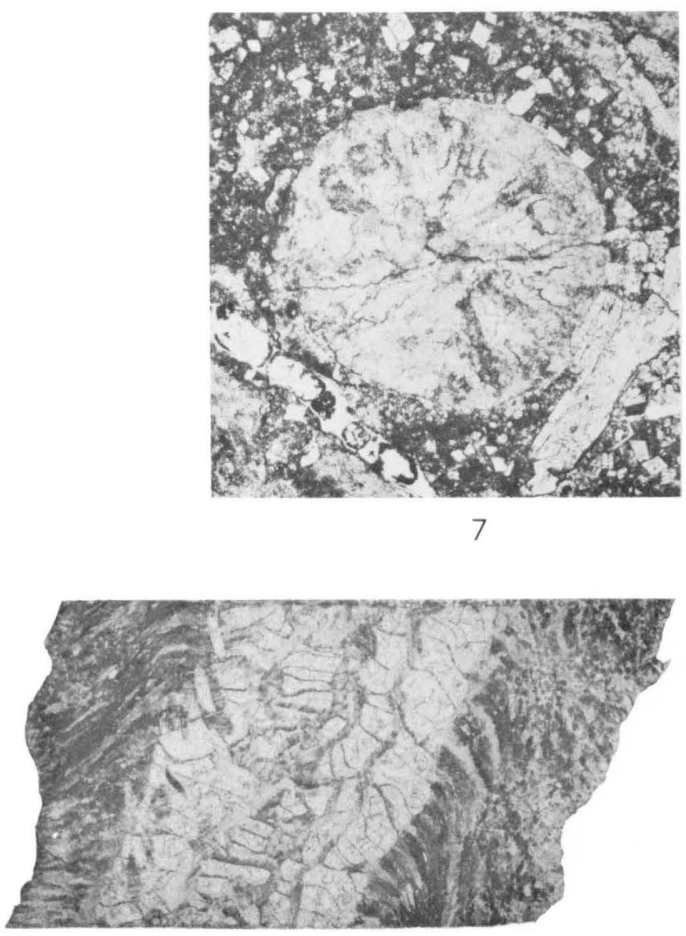

6

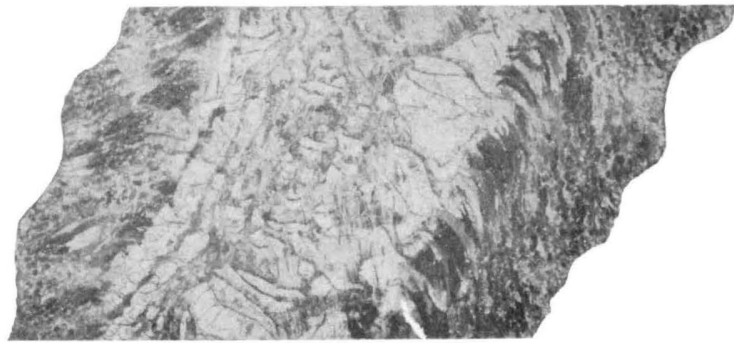

5

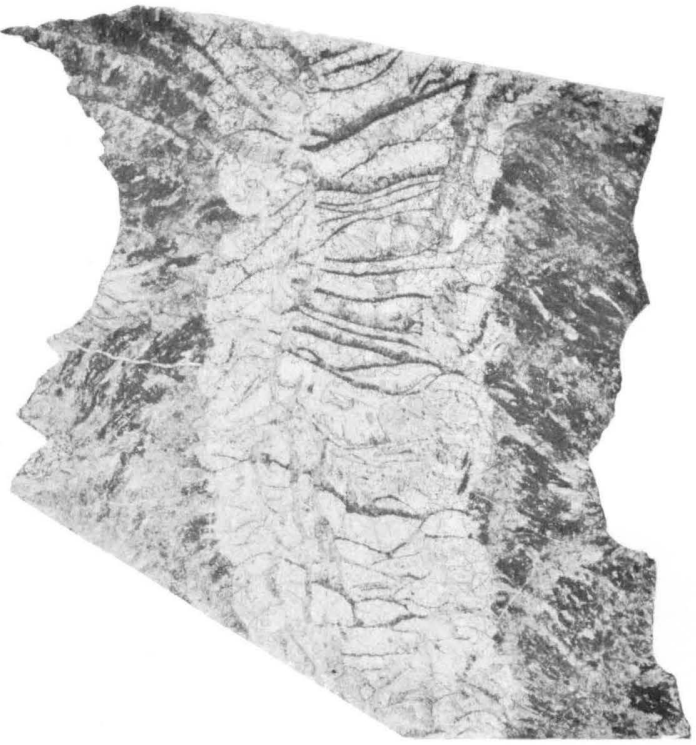

KODONOPHYLLUM CORYMBOSUM N. SP. 


\section{PLATE 10}

FigURes 1-6. Kodonophyllum corymbosum n. sp., USNM 139460 (p. 23).

1-5. Serial transverse thin sections of principal clump of corallites $(\times 1.5)$. Key to individual corallites is given below. Figure 1 is the youngest section. These continue the series of plate 9 , figures $1-3$, and were taken below the longitudinal sections (pl. 9 figs. 4-6).

6. Detail (X 5) of corallite 6 (pl. 9, fig. 1).
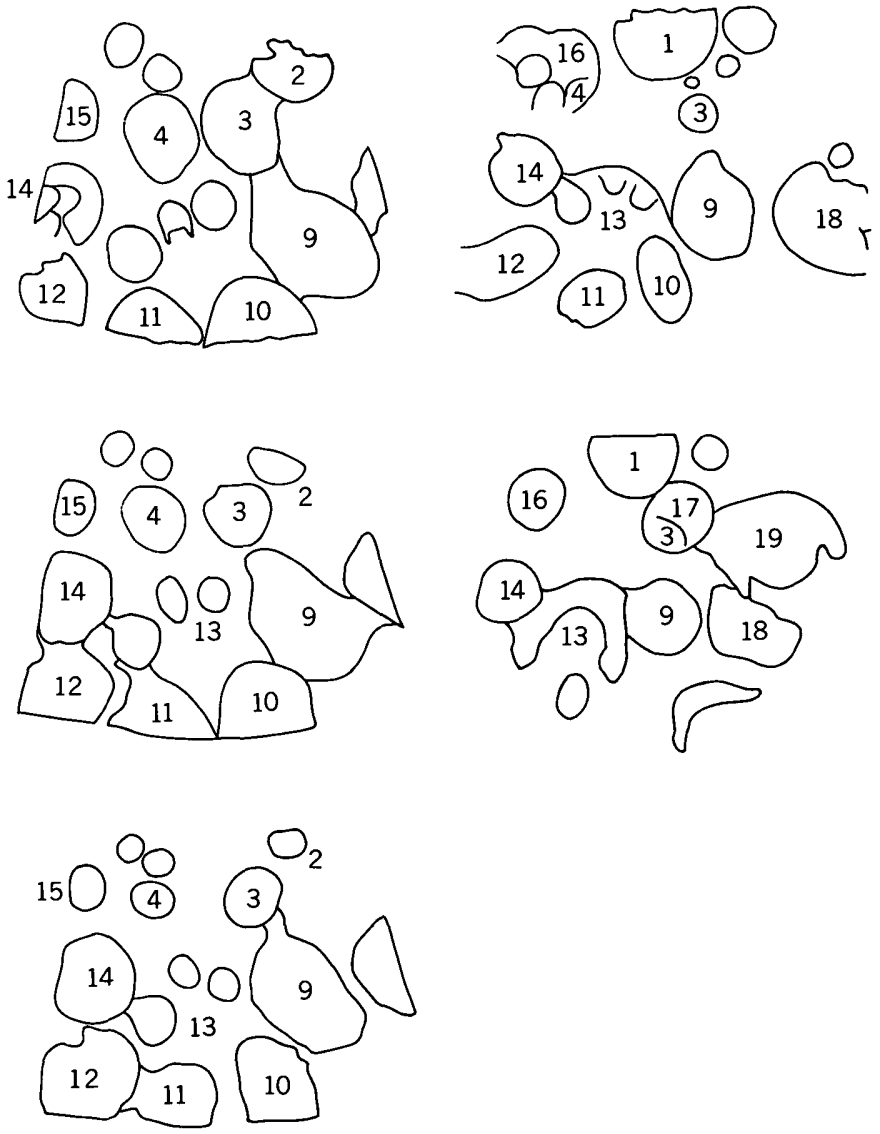

KEY TO SERIAL SECTIONS; PLATE 10, FIGURES 1-5, REDUCED $1 \frac{1}{2}$.

Numbers on the figures mark corallites that can be seen in more than one section. The five sections were cut at about 5-mm intervals and are in descending order.

Figures 1-3 on plate 9 are higher in the same series, but are separated from these 5 sections by a distance of $17 \mathrm{~mm}$. 

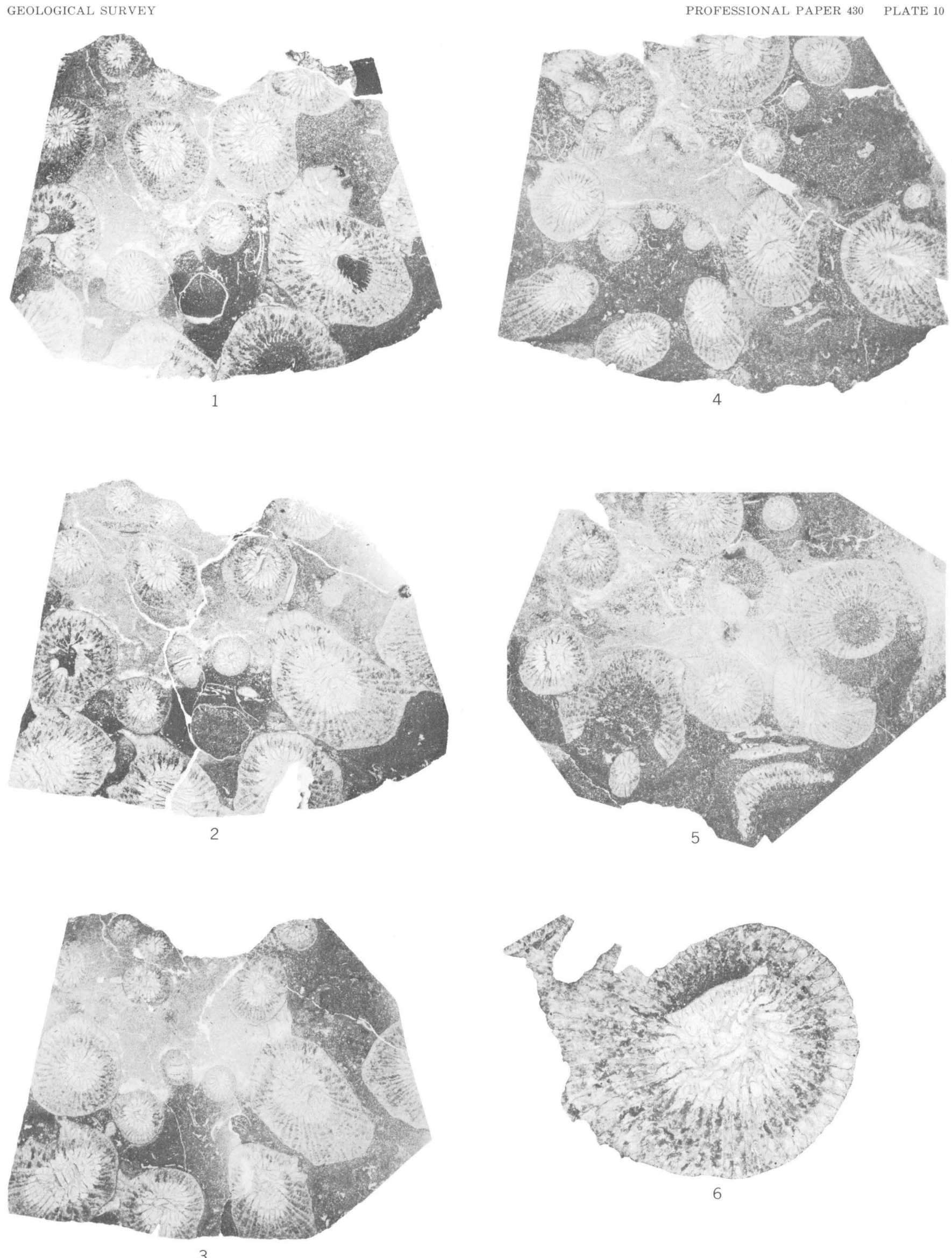

KODONOPHYLLUM CORYMBOSUM N. SP.

$624649 \mathrm{O}-62-7$ 


\section{PLATE 11}

Figures 1-12. Kodonophyllum corymbosum n. sp., USNM 139460 (p. 23). Enlargements of corallite 3 from the serial transverse sections on plates 9 and 10 .

1. Stage 3 offset $(\times 10)$ (pl. 10, fig. 5)

2. Stage 4 offset $(\times 10)$ (pl. 10, fig. 4$)$.

3-5. Developing corallite $(\times 3)$ (pl. 10, figs. 3, 2, 1).

6, 7. Calice sections $(X 3)$ (pl. 9 , figs. 3,2 ).

8. High calice section $(\times 3)$ showing peripheral offsets in various stages of development (pl. 9, fig. 1). $9-12$. Enlargements of offsets shown in figure $8(\times 10): 9$. stage $2 ; 10$. stage $2-3 ; 11$. stage $3 ; 12$. stage 4 . 


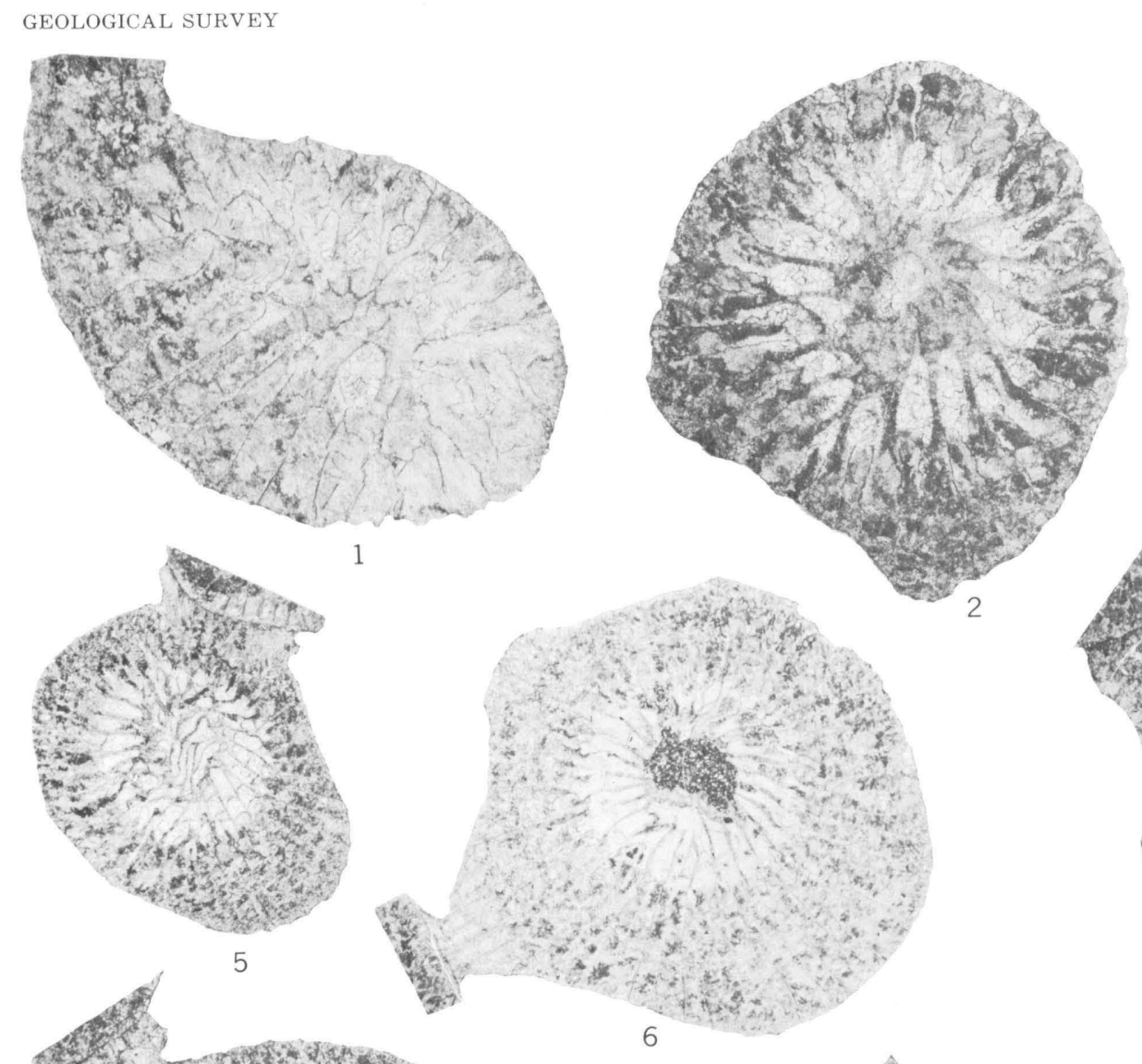

PROFESSIONAL PAPER 430 PLATE 11
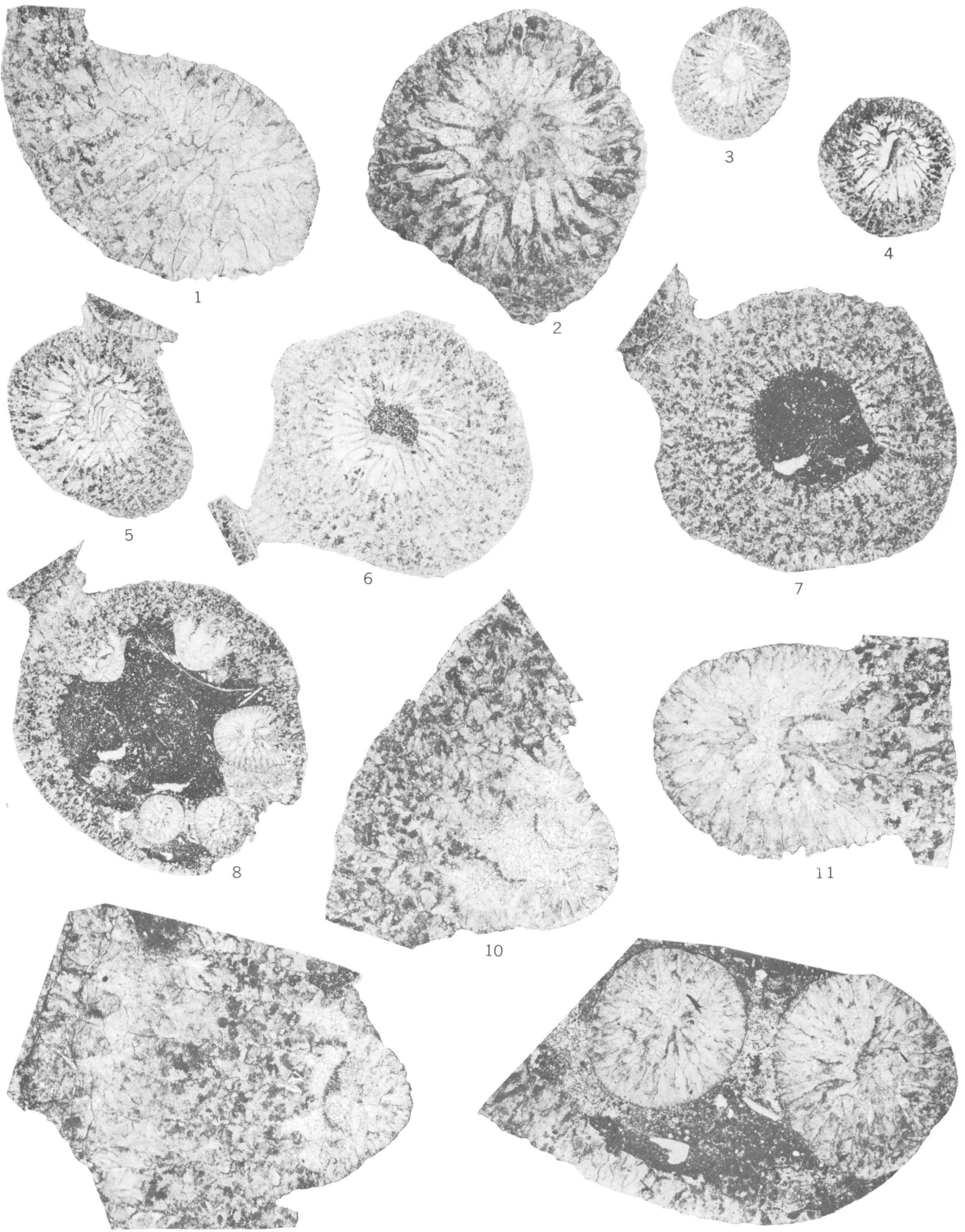

9

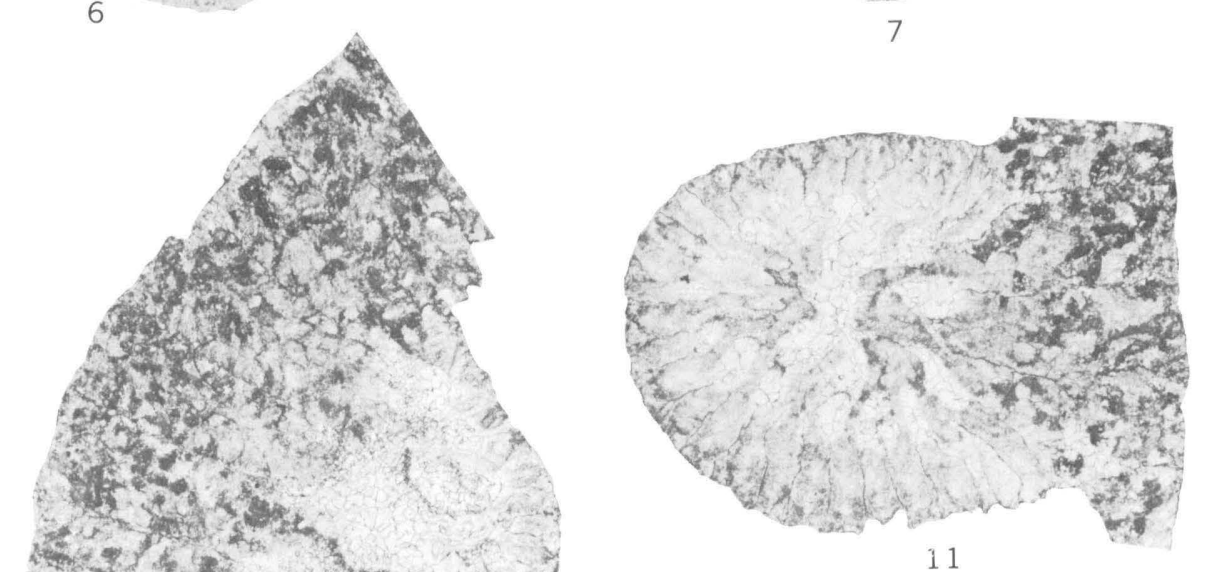

11

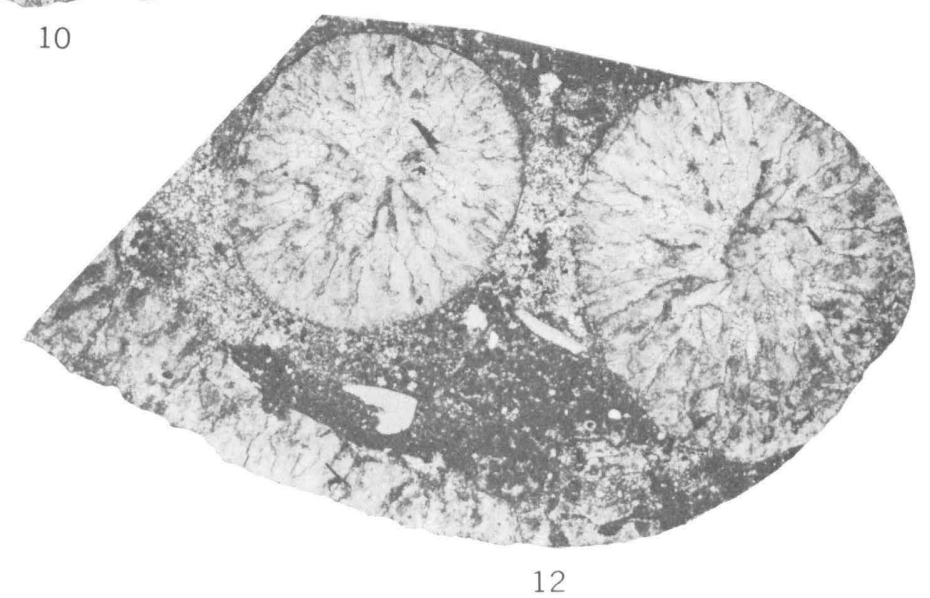

KODONOPHYLLUM CORYMBOSUM N. SP. 


\section{PLATE 12}

FIGURES 1-6. Kodonophyllum corymbosum n. sp., USNM 139460 (p. 23). Enlargements of offsets.

1. Initiation of offsets (stage 1 ) in corallite $7(\times 10)$ (pl. 9, fig. 1).

2, 3. Stage 2 and $2-3$ off sets in corallite 8 ( $\times 10$ ) (pl. 9, fig. 1).

4. Initiation of offset (stage 1) in corallite $13(\times 10)$ (pl. 10, fig. 5)

5 ,6. Stage 3 offsets in corallite $13(\times 20)$ (pl. 10, fig. 4). The offset in figure 6 may be a later stage of that shown in figure 4 . 

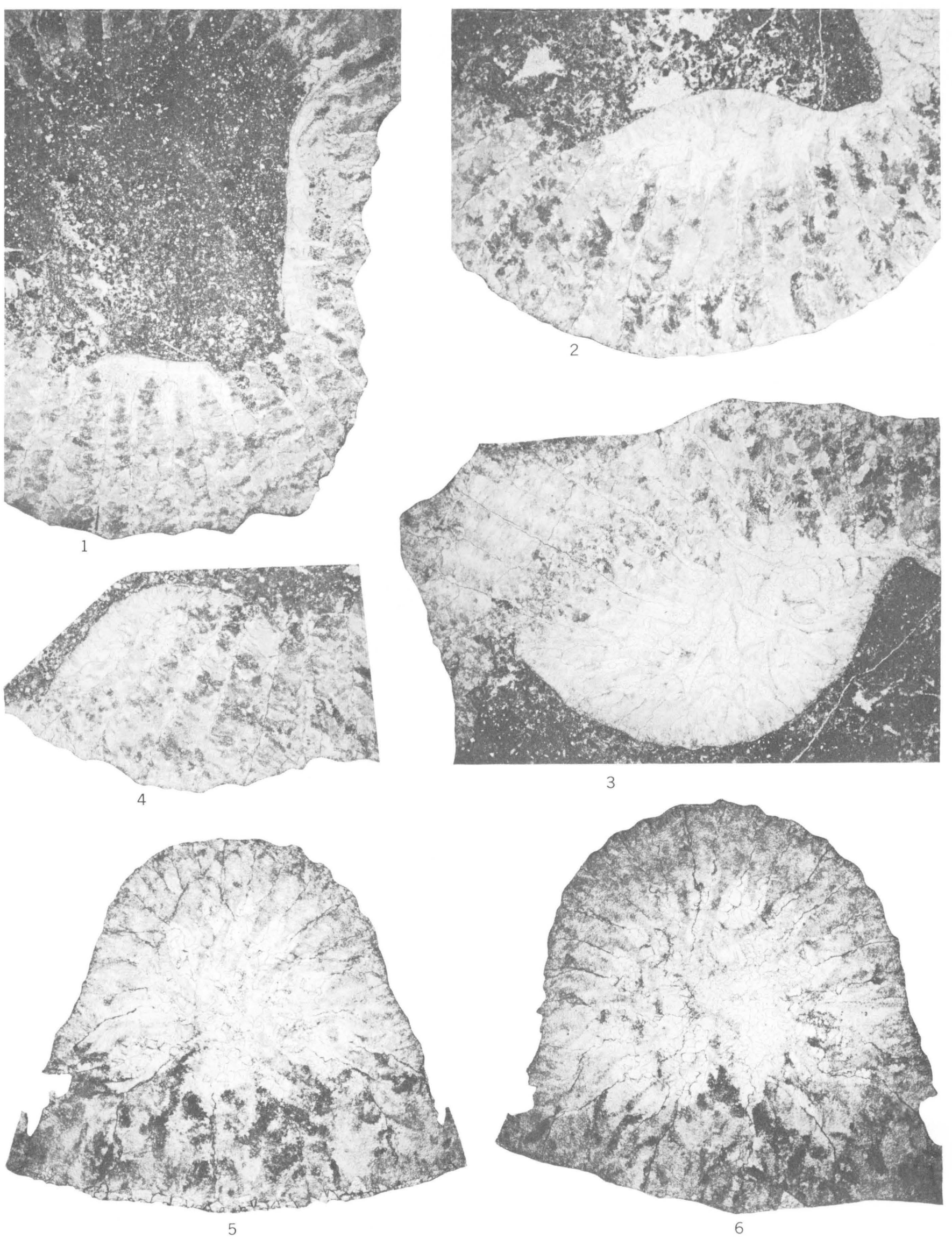

KODONOPHYLLUM CORYMBOSUM N. SP. 


\section{PLATE 13}

FiguRes 1-8. Kodonophyllum corymbosum n. sp. (p. 23).

1-6. USNM 139460. Corallite 14

1-3. Serial sections showing development of offsets $(X 5)$. 1. Beneath the calice (pl. 10, fig. 3); 2. Calice section with stage 2 offsets (pl. 10, fig. 2); 3. More advanced stage (2-3) of same offsets (pl. 10, fig. 1). 4-6. Enlargements of offsets. 4. Part of figure $2(\times 10)$; 5. Same $(\times 20) ; 6$. Part of figure $3(\times 10)$.

7, 8. USNM 139461. Longitudinal and transverse thin sections of small corallite from another locality $(\times 5)$. 

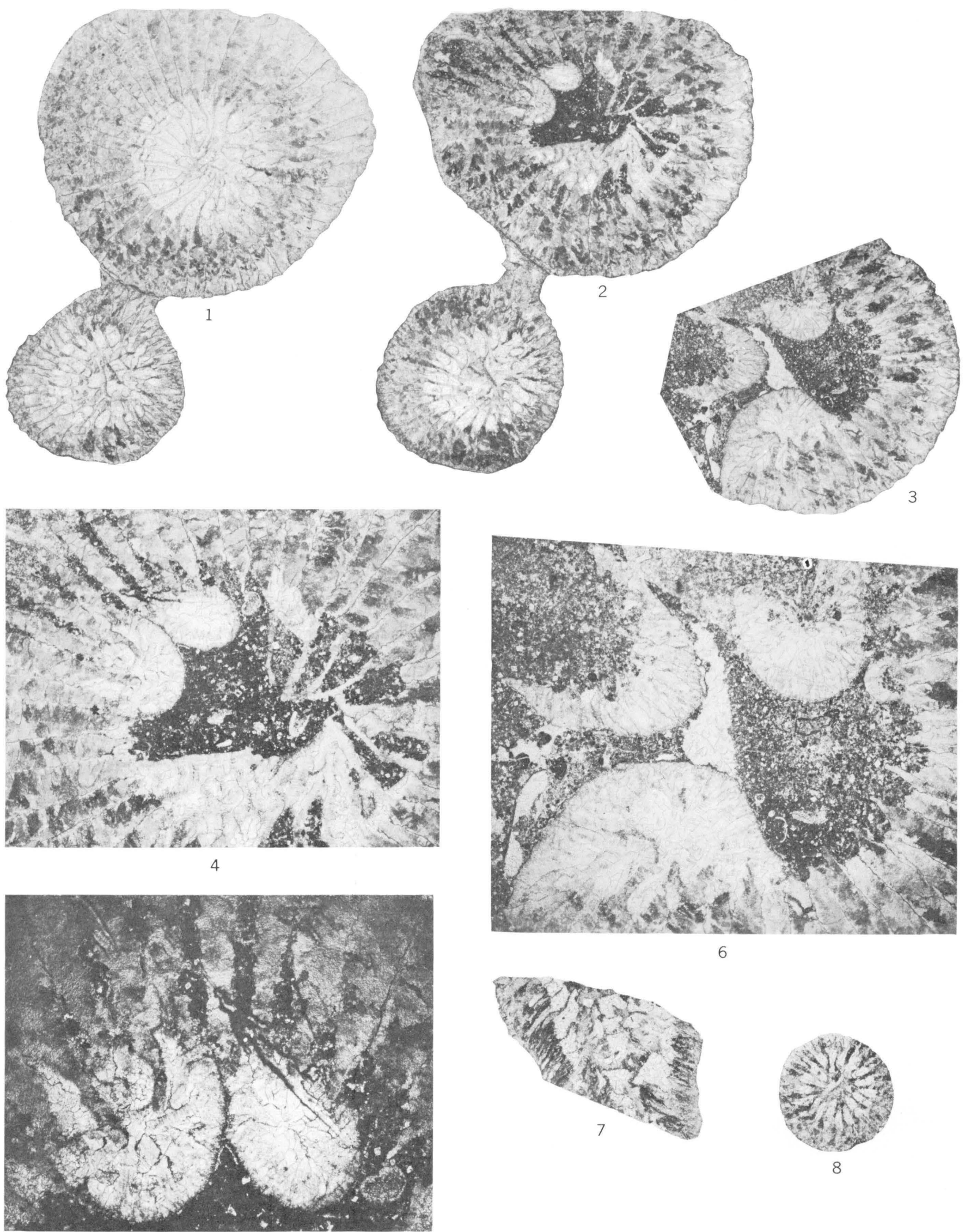

6
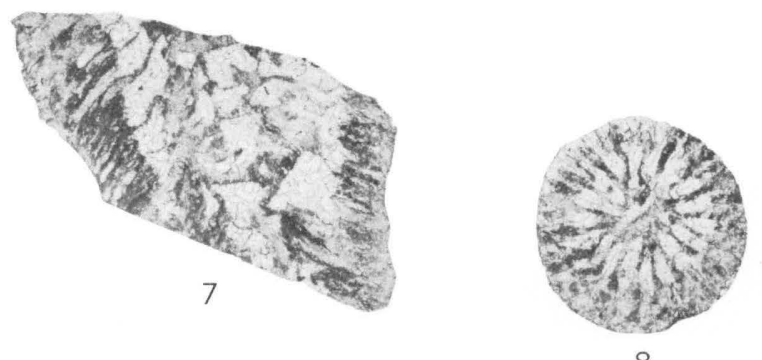

KODONOPHYLLUM CORYMBOSUM N. SP. 


\section{PLATE 14}

FigdRes 1-5. Spongophylloides sp. (p. 28).

[All figures $\times 5$ ]

1, 2. USNM 139465 , transverse and longitudinal thin sections.

3-5. USNM :139466, 3, longitudinal thin section; 4, 5. ephebic and neanic transverse thin sections taken above and below the longitudinal section.

6, 7. Phaulactis sp. (p. 27), USNM 139464; longitudinal and transverse thin sections.

8-12. Briantelasma sp. (p. 27), USNM 139462; longitudinal and serial transverse thin sections; figures 11 and 12 show fossula. 

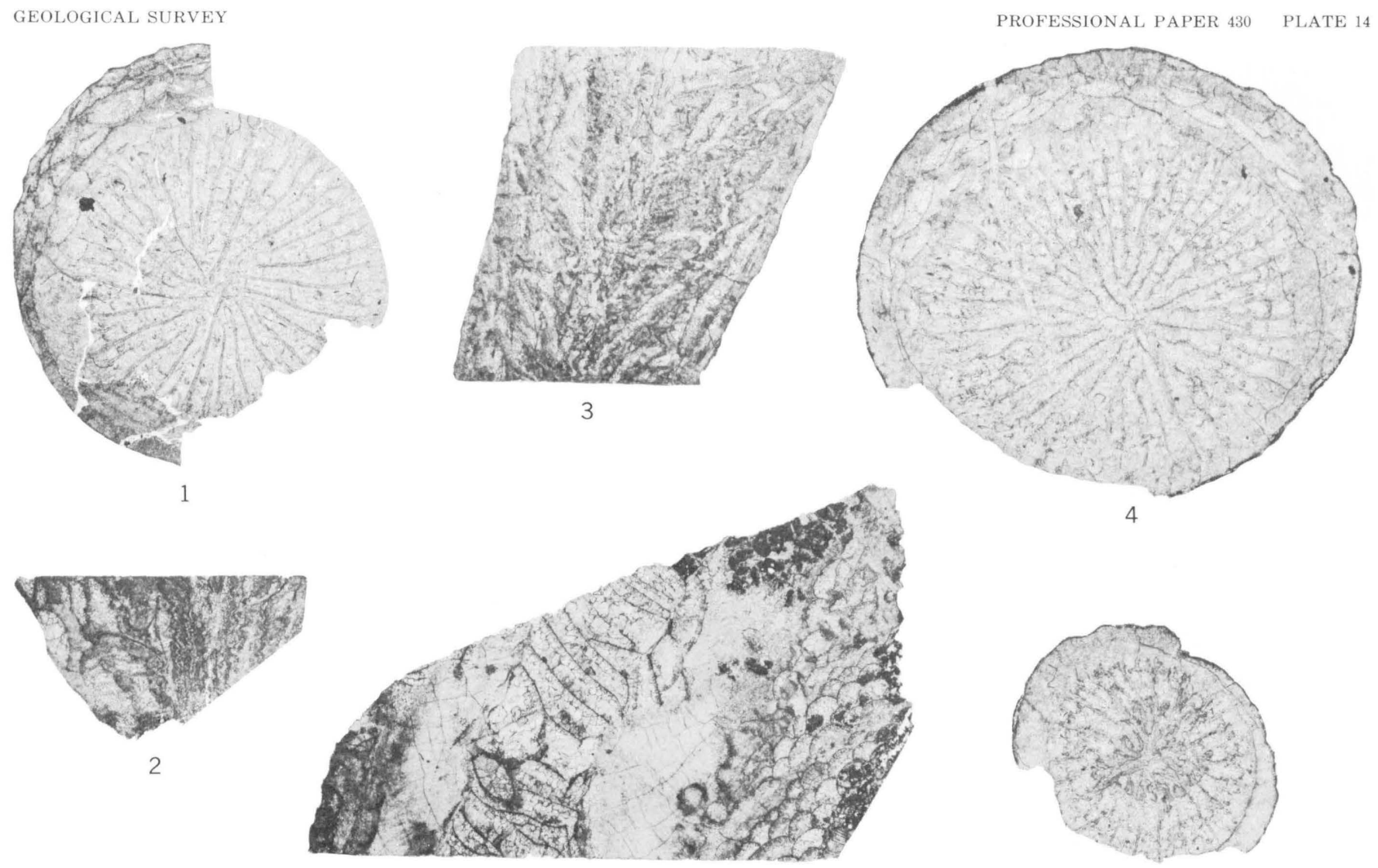

6
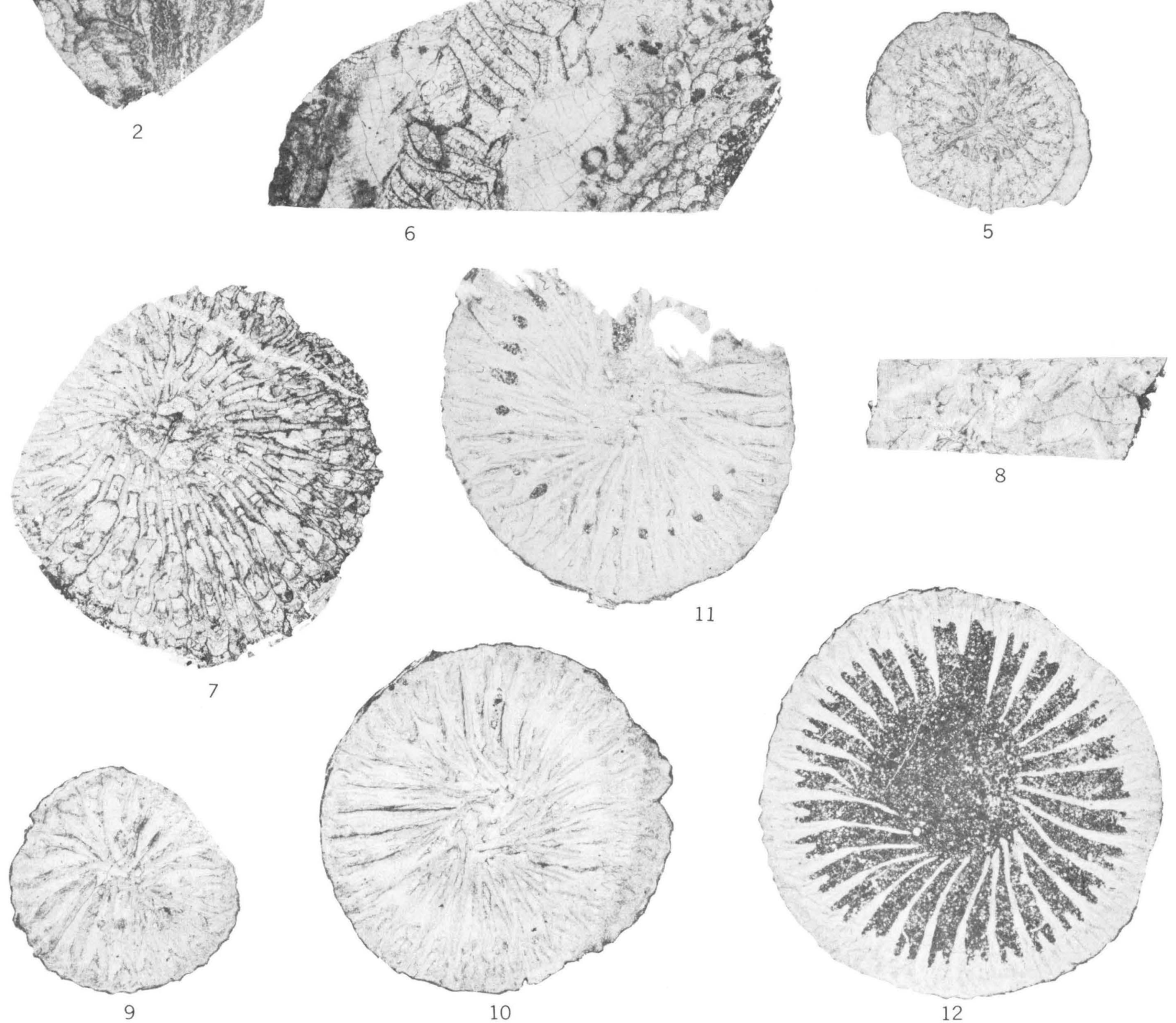

SPONGOPHYLLOIDES, PHAULACTIS. AND BRIANTELASMA SPP. 